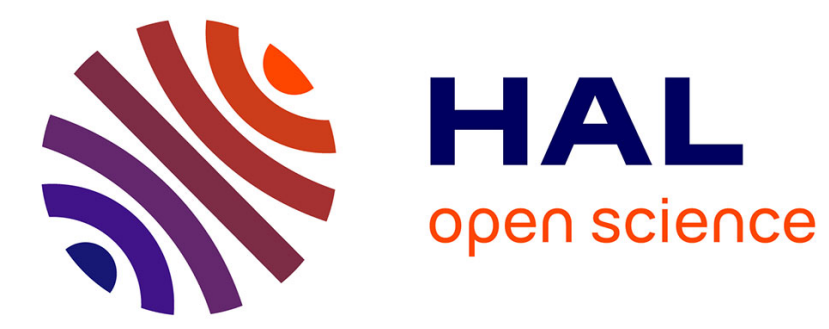

\title{
From Soviets to Oligarchs: Inequality and Property in Russia, 1905-2016
}

Filip Novokmet, Thomas Piketty, Gabriel Zucman

\section{To cite this version:}

Filip Novokmet, Thomas Piketty, Gabriel Zucman. From Soviets to Oligarchs: Inequality and Property in Russia, 1905-2016. 2017. halshs-02659268

\section{HAL Id: halshs-02659268 \\ https://shs.hal.science/halshs-02659268}

Preprint submitted on 2 Jun 2020

HAL is a multi-disciplinary open access archive for the deposit and dissemination of scientific research documents, whether they are published or not. The documents may come from teaching and research institutions in France or abroad, or from public or private research centers.
L'archive ouverte pluridisciplinaire HAL, est destinée au dépôt et à la diffusion de documents scientifiques de niveau recherche, publiés ou non, émanant des établissements d'enseignement et de recherche français ou étrangers, des laboratoires publics ou privés. 


\section{World Inequality Lab Working papers n²017/9}

"From Soviets to Oligarchs: Inequality and Property in Russia, 1905-2016"

Filip Novokmet, Thomas Piketty, Gabriel Zucman

Keywords : Income Inequality; top incomes; distribution; Russia; wealth inequality; private property

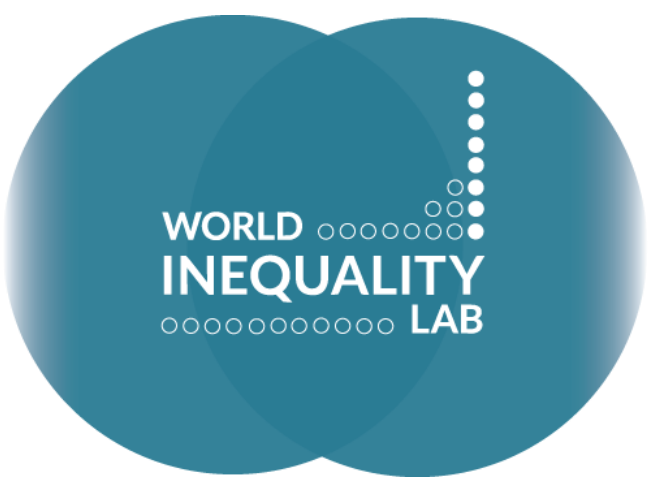

WID.WORLD

THE SOURCE FOR

GLOBAL INEQUALITY DATA

World Inequality Lab 


\title{
From Soviets to Oligarchs:
}

\section{Inequality and Property in Russia 1905-2016}

\author{
Filip Novokmet (Paris School of Economics) \\ Thomas Piketty (Paris School of Economics) \\ Gabriel Zucman (UC Berkeley and NBER)
}

First version: June 20, 2017

This version: April 6, 2018

\begin{abstract}
This paper combines national accounts, survey, wealth and fiscal data (including recently released tax data on high-income taxpayers) in order to provide consistent series on the accumulation and distribution of income and wealth in Russia from the Soviet period until the present day. We find that official survey-based measures vastly under-estimate the rise of inequality since 1990. According to our benchmark estimates, top income shares are now similar to (or higher than) the levels observed in the United States. We also find that inequality has increased substantially more in Russia than in China and other ex-communist countries in Eastern Europe. We relate this finding to the specific transition strategy followed in Russia. According to our benchmark estimates, the wealth held offshore by rich Russians is about three times larger than official net foreign reserves, and is comparable in magnitude to total household financial assets held in Russia.
\end{abstract}

* Filip Novokmet: filipnovokmet@yahoo.com. Thomas Piketty: piketty@psemail.eu. Gabriel Zucman: zucman@berkeley.edu. This paper is supplemented by a data appendix available online. We are grateful to Sergei Guriev, Branko Milanović, Ruslan Yemtsov, Gerard Roland, Petr Fedorov, seminar participants at EBRD, Northwestern University, Stanford University and the Moscow Financial Forum for helpful comments. We thank Anastasiya Lisina who participated in the early stage of this project. We acknowledge financial support from the European Research Council under the European Union's Seventh Framework Programme, ERC Grant Agreement n. 340831 . 
Section 1. Introduction

Section 2. Data Sources, Concepts and Methodology

Section 3. The Rise of Private Property in Russia

Section 4. The Rise of Income and Wealth Inequality in Russia

Section 5. Concluding comments and perspectives

$\underline{\text { References }}$ 


\section{Section 1. Introduction}

Russia has undergone a dramatic economic and political transformation since the fall of the Soviet Union in 1990-1991. Gross domestic product fell abruptly in 1992-1995, while inflation skyrocketed. GDP started to recover in 1998-1999 and a decade of robust growth followed. The world financial crisis and the fall in oil prices interrupted this process in 2008-2009. Growth has been sluggish since then, and the level of economic activity fell again in 2014-2015, partly due to international sanctions following Russian military intervention in Ukraine. However, and despite the inherent difficulties in comparing GDP between Soviet and post-Soviet periods, there is little doubt that average incomes are significantly higher today than in 1989-1990. According to the estimates reported on Figure 1a, per adult national income has increased by about 40\% between 1989 and 2016, from slightly more than $16000 €$ at the end of the Soviet period to almost $24000 €$ in recent years (both expressed in 2016 euros using purchasing power parity exchange rates). If we compare Russia's per adult national income to the Western European average-here defined as the simple arithmetic average of Germany, France and Britain-we find that the gap between Russia and Western Europe has narrowed a bit. Russian living standards were about $60-65 \%$ of the Western European average in 1989-1990, and reached about $70-75 \%$ by the mid-2010s.

This uneasy process of convergence with the West should also be analyzed from a longer run perspective (see Figure 1b). According to the best available estimates, Russia's per adult national income was stagnating at about $35-40 \%$ of Western European levels between 1870 and World War 1. Tsarist Russia was a poor and illiterate country. The ratio between Russia and Western Europe rose spectacularly to as much as $65 \%$ in the aftermath of World War 2. This reflects the modernization strategy followed by the Soviet state after the Bolshevik revolution-based on rapid industrialization and mass investment in basic education-as well as the mediocre growth performance of Western countries during the 1914-1945 period. Russia's relative position then reached a plateau and stagnated at about $55-65 \%$ of Western European levels between 1950 and 1990. One can even detect a relative decline starting in the late 1970 s and during the 1980s, from more than $65 \%$ to less than $60 \%$ (despite the growth slowdown in the West during this period). The stagnation of 
Russian living standards relative to the West between the 1950s and the 1980s, together with rising shortages and general frustration among the educated population, arguably contributed to the complex social and political processes that eventually led to the fall of the Soviet Union. ${ }^{1}$

Yet the consequences on the distribution of income and wealth of the dramatic transformations that occurred since 1989-1990 are not very well documented and understood. There is no doubt that income inequality has increased substantially since 1989-1990, at least in part because monetary inequality was unusually-and to some extent artificially-low under Communism. But little is known about the exact magnitude of the increase. Which income and wealth classes have benefited the most from the post-Soviet transition, and in what proportions? How do Russia's inequality levels compare to those observed in Western capitalist countries, in China, and in ex-communist Eastern European countries?

In this paper, we attempt to combine the various available data sources-national accounts, surveys, wealth rankings, and tax data, including recently released tax data on high-income taxpayers - in a systematic manner to provide consistent series on the accumulation and distribution of income and wealth in Russia from the Soviet period until the present day.

Our contributions are both methodological and substantial. First, from a methodological viewpoint, we provide what is to our knowledge the first attempt to exploit Russian national income tax tabulations to correct official survey-based inequality estimates. ${ }^{2}$ We find that surveys vastly under-estimate the rise of inequality since 1990. According to our benchmark estimates, top income shares are now at

\footnotetext{
${ }^{1}$ The best indicator of the mediocre Soviet economic and social performance in the post-World War 2 decades is probably the stagnation of life expectancy; see, e.g., Todd (1976). Life expectancy is better measured and to a large extent more informative than national income. Similarly, Brainerd and Cutler (2005) find a sharp decline in life expectancy in Russia between 1989 and 1994. Also note that using the West European average income as a reference point is clearly an over-simplificiation and does not do justice to the complexity of country-specific trajectories. For instance, Germany, France and Britain have quasi-identical average income in 2016, but Britain was lagging behind Germany and France in 1980 (only slightly above Russian level), and was on the contrary well ahead in 1870-1914. See Appendix B, Figures B1-B2.

2 Previous studies used leaked income tax declarations for the city of Moscow for year 2004 (see Guriev and Ruchinsky, 2006, and section 2.2 below), but to our knowledge the national annual income tax tabulations have never been used before.
} 
least as high than in the United States, with a top 1\% income share around $20-25 \%$. We also find that inequality has increased substantially more in Russia than in China and ex-communist Eastern European countries, a finding we relate to the specific transition strategy followed in Russia.

Second, we combine various official and non-official series to provide the first complete balance sheets for private, public, and national wealth in post-Soviet Russia, including an estimate for offshore wealth. According to our benchmark estimates, offshore wealth is about three times larger than official net foreign reserves (about $85 \%$ of national income vs. around $25 \%$ ), and is comparable in magnitude to total onshore household financial assets. That is, there is as much financial wealth held by rich Russians abroad-in the United Kingdom, Switzerland, Cyprus, and similar offshore centers-than held by the entire Russian population in Russia itself.

In brief, our new findings reveal an extreme level of inequality in Russia and a persistent concentration of rent-based resources-which are unlikely to be the best recipes for sustainable development and growth. While our results have implications for the growth and convergence prospects of Russia (and more broadly for the role of policies, institutions, and ideology in inequality dynamics), we stress that the present paper is essentially focused on measuring inequality and explaining how the various existing sources can be combined. Our modest objective is to make explicit what we know and do not know about inequality in Russia, and to put Russia's inequality trajectory in historical and comparative perspective. More data is required before we can make further progress in interpreting the findings.

This paper is part of a broader project, the World Wealth and Income Database (WID.world), that attempts to produce distributional statistics that are comparable across countries. To make the statistics as comparable as possible, we follow a common methodology that involves combining national accounts, surveys, and fiscal data in a consistent manner to produce "distributional national accounts". This methodology was already applied in the United States (Saez and Zucman, 2016; Piketty, Saez and Zucman, 2016), France (Garbinti et al, 2016, 2017) and China (Piketty, Yang and Zucman, 2017). This is an ongoing project, and we have no doubt 
that the Russian series reported in the present paper will be improved in the future, as refined methods are designed and better data sources (hopefully) become available. All updates will be posted online at WID.world.

The rest of this paper is organized as follows. In section 2 we describe our main data sources, concepts, and methodology. Section 3 presents our results on the evolution of private wealth, public wealth, offshore wealth and national wealth-national income ratios in Russia and compare these findings to other countries. In section 4 we present our results on the evolution of income and wealth inequality in Russia, which we also compare to other countries. Section 5 provides concluding comments. This paper is supplemented by an extensive online Appendix that includes all our raw data sources and computer codes and presents additional results and robustness checks. $^{3}$

\section{Section 2. Data Sources, Concepts and Methodology}

This paper relies on five types of data sources: national income and wealth macro accounts, household income surveys, income tax data, household wealth surveys, and wealth rankings. We start by describing the macro data sources, and then proceed with distributional data. Our concepts and methods generally follow those described in the Distributional National Accounts guidelines used for the World Wealth and Income Database (Alvaredo et al., 2016). In this section, we focus on the main conceptual and empirical issues; complete methodological details are provided in the online Appendix.

\section{Section 2.1. National income and wealth series}

Section 2.1.1. Basic concepts and conceptual framework

We follow the U.N. System of National Accounts (SNA 2008) conceptual framework and the definitions used by Piketty and Zucman (2014) and Alvaredo et al (2016). By combining official Russian official national accounts series together with a number of

\footnotetext{
${ }^{3}$ The data appendix is available online at http://piketty.pse.ens.frl, http://gabriel-zucman.eu/russia, and http://WID.world.
} 
unofficial balance sheet estimates and sources, we provide consistent series for national income, national wealth, and their components over the 1990-2015 period.

National income $Y_{t}$ is defined in the standard manner: GDP minus capital depreciation plus net foreign income. Private wealth $W_{t}$ is defined as the total value of assets owned by households and non-profit institutions, minus their debt. ${ }^{4}$

Following SNA guidelines, assets include all the non-financial (real) assets - housing, land, buildings, machines, intellectual property etc. - and financial assets - including life insurance and pensions funds - over which ownership rights can be enforced and that provide economic benefits to their owners. Pay-as-you-go social security pension wealth is excluded, just like all other claims on future government expenditures and transfers (like education expenses for one's children and health benefits). Durable goods owned by households, such as cars and furniture, are excluded as well. Nonfinancial assets are the only "real" assets, in the sense that financial assets and liabilities exactly balance each other at the world level and do not contribute to global net wealth. As a general rule, all assets and liabilities are valued at their prevailing market prices. Corporations are included in private wealth through the market value of equities owned by households. Unquoted shares are typically valued on the basis of observed market prices for comparable, publicly traded companies.

We similarly define public (or government) wealth $W_{g t}$ as the net wealth of public administrations and government agencies. In available balance sheets, public nonfinancial assets like administrative buildings, schools and hospitals are valued by cumulating past investment flows and upgrading them using observed real estate prices. We define market-value national wealth $W_{n t}$ as the sum of private and public wealth: $W_{n t}=W_{t}+W_{\text {gt }}$. National wealth can also be decomposed into domestic capital and net foreign assets: $W_{n t}=K_{t}+N F A_{t}$. Domestic capital $K_{t}$ can in turn be decomposed as the sum of agricultural land, housing, and other domestic capital (including the market value of corporations, and the value of other non-financial assets held by the private and public sectors, net of their liabilities).

\footnotetext{
${ }^{4}$ At this stage Russian data sources do not allow do decompose private wealth into personal wealth (households) and non-profit wealth (non-profit institutions, usually a relatively small part of private wealth), so we only provide series for aggregate private wealth (personal plus non-profit).
} 
An alternative measure of the wealth of corporations is the total value of corporate assets net of non-equity liabilities, what we call the corporations' book value. We define residual corporate wealth $W_{c t}$ as the difference between the book-value of corporations and their market value (which is the value of their equities). By definition, $W_{c t}$ is equal to 0 when Tobin's $Q$ - the ratio between market and book values - is equal to 1 . In practice, there are several reasons why Tobin's $Q$ can be different from 1, so that residual corporate wealth is at times positive, at times negative. We define book-value national wealth $W_{b t}$ as the sum of market-value national wealth and residual corporate wealth: $W_{b t}=W_{n t}+W_{c t}=W_{t}+W_{g t}+W_{c t}$. Although we tend to prefer our market-value concept of national wealth (or national capital), both definitions have merit. $^{5}$

Balance sheets are constructed by national statistical institutes and central banks using many census-like sources, in particular reports from financial and non-financial corporations about their balance sheet and off-balance sheet positions, and housing surveys. The perpetual inventory method usually plays a secondary role. The interested reader is referred to Piketty and Zucman (2014) for a precise discussion of the methods used by the leading rich countries.

Section 2.1.2. Special issues with Russia's national income and wealth accounts

National income series for Russia in the post-1990 period are based on the official Rosstat's national accounts. For the 1960-1990 period, we use retrospective national accounts for Russia produced by Ponomarenko (2002), who adjusts the official series based on the Material Product System (MPS) to relevant SNA definitions. ${ }^{6}$ See Appendix section A.2. for all details on sources and computations.

\footnotetext{
${ }^{5} \mathrm{~W}_{\mathrm{bt}}$ corresponds to the concept of "national net worth" in the SNA (see Piketty and Zucman 2014, Data Appendix A.4.2). We use "national wealth" and "national capital" interchangeably (and similarly for "domestic wealth" and "domestic capital", and "private wealth" and "private capital"), and specify whether one uses "market-value" or "book-value" aggregates.

${ }^{6}$ There is a great uncertainty regarding the size of the output collapse in the early 1990s. We make upward correction of growth in the $1990-5$ period by revising the GDP deflator, as using the official Rosstat growth rates would imply implausibly high living standards in Russia during the Soviet period (as a proportion of Western European living standards).
} 
In the case of Russia's balance sheets, all details about data constructions and raw sources are given in Appendix A. A number of additional remarks are in order. First, we put special attention at estimating offshore wealth. Generally speaking, the issue of offshore wealth and cross-border assets has become increasingly important at the global level in recent decades (see Zucman 2013, 2015). Russia is arguably the country in the world where this issue has become the most significant. As we will see in section 3 when we present our results, there are major discrepancies in Russia's basic economic and financial statistics, and in particular there is a large gap between very high trade surpluses during the 1990-2015 period and relatively limited accumulation of net foreign assets.

Capital flight and offshore wealth are natural candidates to explain this paradox, and in this paper we propose a method and an estimate for the likely magnitude of offshore wealth. By definition, such an estimate is bound to be approximate. But given the quantitative importance of this issue in the case of Russia, we feel that it is preferable to provide a plausible estimate (based upon a transparent method using the large cumulated "errors and omissions" residual in Russia's balance of payment) rather than to ignore the issue altogether. As we shall see, the question of offshore wealth plays a significant role for the overall analysis of national wealth accumulation in Russia and in comparison to other countries.

Next, we focus on post-1990 balance sheets in the context of this paper, and we do not attempt to use existing estimates and data series on Soviet and pre-Soviet balance sheets. There exists a long and voluminous tradition of balance sheets and capital accumulation accounts in the Soviet Union. However the system of relative prices used in these capital accounts has little resemblance to the post-Soviet period, so we choose to begin our balance sheet series in 1990. There also exists some balance sheet estimates for the pre-Soviet period, which to some extent are more comparable to the modern estimates and to the contemporary estimates for other countries. Existing estimates for 1913 typically show national wealth around 500$600 \%$ of national income, with a large share of agricultural land (see e.g. Goldsmith 1965). If they were to be compared to the post-1990 estimates reported in the present paper, the very long run pattern for Russia would be similar to that observed 
for Western countries (Piketty and Zucman, 2014): large and relatively stable national wealth-national income ratios in the very long run, but with major changes in composition (agricultural land being replaced by housing and other domestic capital).

Section 2.2. Series on income and wealth distribution in Russia

Section 2.2.1. Income distribution series

We construct our income distribution series by combining national accounts, survey, wealth, and fiscal data. More precisely, we proceed in three steps: we start from household income survey data (step 1), which we correct using income tax data on high-income individuals and generalized Pareto interpolation techniques (Blanchet, Fournier and Piketty, 2017) (step 2). We then use national accounts and wealth inequality data in order to impute tax-exempt capital income (step 3). All corresponding computer codes and robustness checks are provided in the appendix.

This methodology in three steps mirrors that used for China by Piketty, Yang, Zucman (2017), with a number of important differences. In particular, the income tax data takes a different form in Russia and in China. In China, a relatively standard progressive income tax system (with graduated tax rates from $0 \%$ to $45 \%$ ) has been in place (with minor changes) since 1980, but we only know the number and total income of taxpayers with annual taxable income above a certain threshold (usually 120000 yuans), and the data is only available on an annual basis since 2006.

Russia, by contrast, has a flat $13 \%$ income tax since 2001. In 2008, the tax administration started to release annual tabulations that are in some ways richer than the Chinese data, in the sense that they provide information on the numbers of taxpayers for a larger number of brackets of "assessable income," including very high 
brackets (taxpayers with annual incomes between 10 and 100 million rubles, 100 and 500 million, 500 million and 1 billion, 1 and 10 billion, and over 10 billion rubles). ${ }^{7}$

Unfortunately there are two major limitations with these tabulated statistics. First, the concept of "assessable income" used in these tabulations resembles a "gross revenue" concept (rather than an "income" concept), in the sense that all personal revenues are taken into account, before any deductions (in particular before deductions such as professional expenses for entrepreneurial income, or asset acquisition price and other costs for capital gains, etc.). ${ }^{8}$ Other tables released by Russian tax authorities do provide information about how total deductions compare to total revenues, but this information is not available at the bracket level, so we need to make assumptions in order to exploit the data. In our benchmark series, we assume the same deduction rate for all brackets.

The other major difficulty (which biases the data in the opposite direction) is the fact that not all taxpayers need to submit an income declaration in Russia's personal tax system. In principle, taxpayers whose income is entirely reported by tax agents (i.e., who only earn wages reported by employers, and/or interest and dividends reported by financial institutions) do not need to submit a declaration. For them, the $13 \%$ flat income tax withheld at source is considered as final. The declaration is only compulsory for taxpayers who also receive other income (such as entrepreneurial

\footnotetext{
${ }^{7}$ See Appendix B, Table B11 for the raw tabulated data. In 2016, $1 €=74.5$ rubles (market exchange rates) or 28.3 rubles (PPP). In most years between 2008 and 2015, we have typically about $400-500$ taxpayers with assessable income above 1 billion rubles, and 30-50 with assessable income above 10 billion rubles (i.e. above 150 million dollars using market exchange rates). Needless to say, these are income levels that are never visible in household survey data. According to Forbes magazine (The World's Billionaires list), there are during this period about 100 Russian billionaires with average wealth around 3-4 billion dollars, which may deliver annual income flows of the order of 100-200 million dollars (assuming an average rate of return around $4-5 \%$ ). Of course we have no way to know whether Russian billionaires pay income tax in Russia: according to Forbes most of them are Russian residents (see Figure 2 below and online appendix), but this does not tell us much about the legal arrangements governing their assets and income flows. At least the orders of magnitude are comparable.

${ }^{8}$ The reason why the tax administration uses "assessable income" (i.e., gross revenue) to tabulate income declarations instead of "taxable income" (i.e., gross revenue minus deductions) is unclear and might be due to tax audit strategy: in effect this is a way to keep track of all declarations with large revenues (before deductions are used to reduce taxable income to much lower levels). Also note that in some cases foreign residents are not allowed to claim deductions, so that in effect the flat tax rate applies to their gross revenue rather than their taxable income, which can make an enormous difference (in addition, the flat tax rate applicable to foreign residents is generally $30 \%$ rather than $13 \%$ for most income sources; this might contribute to explain why most Russian billionaires are Russian residents according to Forbes; see below). See Appendix B for details on Russian tax law and data.
} 
income, capital gains, foreign income, gifts, etc.) on which the tax has not been withheld at source. Taxpayers who do not receive such incomes must also submit a declaration in case they want to claim personal deductions (such as deductions for charitable giving, education or health expenses, mortgage payments, etc., with the exception of deductions for dependent adults and children, which are already taken into account at source). In order to properly exploit the data, we need to make assumptions on what fraction of taxpayers file a declaration. In all variants, we assume that very top income taxpayers all file declarations.

Given these limitations of the raw income tax data, we present in the appendix a large number of variants based upon different alternative hypothesis about the profile of deduction rates and declaration rates. In section 4 below, we focus upon our benchmark series, which are relatively conservative and deliver intermediate inequality levels in the range of variants that we consider. We should stress that in all possible variants, the numbers of very high income taxpayers are much higher according to tax data than in self-reported survey data, so that our corrected inequality estimates (and in particular our corrected top 10\% and top $1 \%$ income shares) are much larger than what raw survey data imply. ${ }^{9}$ That being said, it is clear that the income tax tabulations that are currently available in Russia are imperfect. ${ }^{10}$ The publication of improved tabulations would make it possible to construct more precise and detailed estimates of income inequality in Russia.

As far as we know, it is the first time that Russia's national income tax tabulations (which are available on Russian tax authorities' website) are used by researchers. Some researchers used a sample of individual-level income declarations from the city of Moscow that was leaked in 2004. The sample includes a lot more information than the tabulations we use in this paper, but unfortunately the data was not national and covered only few years. What is reassuring for our purposes is that the Moscow data led to quantitative results that are broadly similar to what we find here: the Gini coefficient jumped from about 0.3-0.4 in self-reported survey data to over 0.6 using

\footnotetext{
${ }_{9}^{9}$ See Appendix B, Figures B40-42.

${ }^{10}$ Ideally, Russian tax authorities should release tabulations by brackets of taxable income (and not only by brackets of "assessable income", i.e. gross revenue), reporting the amounts of total taxable income and of the various income subcomponents for each bracket (and not only the numbers of taxpayers), and covering the entire taxpayer population (including taxpayers whose income is reported by tax agents rather than through a declaration). The first improvement would already be substantial.
} 
the leaked tax data, and the top $10 \%$ income share moved from about $30 \%$ to over $50 \%$ of total income (see Guriev and Ruchinsky 2006, Table 4).

All details about the national income tax tabulations and the resulting estimates are provided in the online appendix. Regarding household survey data, we use the RLMS survey data (over the 1994-2015 period) and the HBS survey data for earlier years (HBS data is available over the 1989-2015 period; comparable Soviet surveys were conducted in 1980, 1985 and 1988 and we also use them). Both surveys (RLMS and HBS) have well-known advantages and limitations. ${ }^{11}$ We assume that they provide an acceptable description of the distribution of income below the $90^{\text {th }}$ percentile $\left(p_{0}=0.9\right)$. In order to exploit the income tax tabulations available over the 2008-2015 period, we apply generalized Pareto interpolation techniques (Blanchet, Fournier and Piketty 2017) and piecewise-linear correction factors $f(p)$ above $p_{0}$ up to the percentiles provided by the tax data in order to correct the top part of the distribution (similarly to the method used by Piketty-Yang-Zucman 2017, and described in Alvaredo et al 2016). The resulting increase in top decile Pareto coefficients is used in order to correct survey-estimated Pareto shapes over the 1980-2007 period. In effect, this results into small upward corrections of raw survey inequality over the 1980-1990 period, and gradually increasing upward corrections after 1990 (see section 4 below, figures 10a-10c). ${ }^{12}$

Finally, we use tabulated data from Soviet earnings and income surveys that were already used for years 1928, 1934, 1956, 1959, and regularly until 1989 by other researchers (see in particular Bergson 1942, 1944, and the major work by Atkinson and Micklewright 1992, who provide an extensive collection of tabulated survey data for Russia and Eastern European countries under Communism; see also Flemming and Micklewright 2000 for a survey). In order to provide a comparison with pre-Soviet

\footnotetext{
${ }^{11}$ With RLMS, we have access to individual micro-files and a detailed income questionnaire, but the survey suffers from sample attrition, ageing and declining-inequality bias at the end of the period (see Kozyrera et al 2015; see also Milanovic and Ersado 2010). With HBS, the sampling frame is more consistent over time, but income is measured indirectly (via consumption and change in financial saving), and only rudimentary and relatively opaque tabulations are available (see Yemstov 2008). See online appendix for more details on we combine the two surveys.

${ }^{12}$ This simply comes from the fact that raw survey data Pareto shapes are very low in pre-1990 surveys and quickly rise afterwards. The resulting 1990-2007 profile of rising inequality appears to be relatively robust, but it is evident that it would be preferable to have access to income tax tabulations prior to 2008. Unfortunately no such data seems to exist (except the 2004 leaked fiscal data from Moscow city, which yields consistent upgrade factors and tends to validate our approach).
} 
inequality, we also use the income distribution table that was estimated by Tsarist tax authorities for year 1905 in preparation for the possible introduction of an income tax (which was finally not introduced, so this cannot be compared to actual data). ${ }^{13}$ As we explain in section 4 below, the precision of the resulting estimate should not be over-estimated, but the orders of magnitude appear to be plausible. ${ }^{14}$

\section{Section 2.2.3. Wealth distribution series}

We also provide wealth distribution series for Russia over the 1995-2015 period (which we then use to allocate tax-exempt capital income). In order to construct these estimates, we use Forbes billionaire data and apply generalized Pareto interpolation techniques. Two remarks are in order here.

First, as we further explain in section 3 when we present the resulting estimates, there is substantial uncertainty about the exact level of wealth concentration in Russia. The number of Russian billionaires-as registered in international rankings such as the Forbes list-is extremely high by international standards. According to Forbes, total billionaire wealth was very small in Russia in the 1990s, increased enormously in the early 2000 s, and stabilized around $25-40 \%$ of national income between 2005 and 2015 (with large variations due to the international crisis and the sharp fall of the Russian stock market after 2008). This is much larger than the corresponding numbers in Western countries: Total billionaire wealth represents between $5 \%$ and $15 \%$ of national income in the United States, Germany and France in 2005-2015 according to Forbes, despite the fact that average income and average wealth are much higher than in Russia. This clearly suggests that wealth concentration at the very top is significantly higher in Russia than in other countries (see Figure 2).

The problem, however, is that billionaire data is about very small groups of individuals (about 100 billionaires who are Russian citizens at the end of the period,

\footnotetext{
${ }^{13}$ This 1905 estimate has been used by Gregory (1982) and Lindert and Naziger (2012).

${ }^{14}$ Bergson (1984, p.1077) also provides earnings tabulations for 1914 with relatively high pre-war inter-decile ratios P90/P10 (5.55 in 1914, vs 3.66 in 1928 and 3.74 in 1934; see also Bergson 1942 p. 236). This is consistent with the relatively high inequality estimate for 1905 . See Appendix B tables.
} 
most of whom are Russian residents according to Forbes). One needs to make fairly strong assumptions in order to move from there to estimates of the top $10 \%$ or even the top $1 \%$ and top $0.1 \%$ of the distribution. In the appendix we present a number of alternative series based upon explicit assumptions and generalized Pareto interpolation techniques. Unfortunately, there is significant uncertainty about these estimates. We know that Russia is a country with large wealth inequality, but we do not know the precise extent of wealth concentration (for instance, we cannot provide a precise comparison with the US). We very much hope that new data sources and methods will be developed in the future so as to improve these estimates. We return to this discussion when we present our benchmark series in section $4 .^{15}$

Even though there is significant uncertainty about the exact magnitude of wealth concentration, this has relatively limited impact on our final income inequality estimates. As described above, we use the wealth inequality estimates to allocate tax-exempt capital income (typically undistributed corporate profits and imputed rent), assuming that the joint distribution of fiscal income and non-fiscal income (i.e. taxexempt capital income) follows a Gumbel copula with parameter $\theta=3 .{ }^{16}$ We show that using the different alternative wealth inequality series has very little effect on final top income shares series, first and foremost because top fiscal income shares are already very large (suggesting that they already incorporate a substantial part of top economic capital incomes and business incomes), and next because non-fiscal income is not a very large income component and all wealth inequality series are characterized by large concentration. ${ }^{17}$

\footnotetext{
${ }^{15}$ Other researchers have used billionaire data and Pareto interpolation techniques in order to estimate top wealth shares in Russia and other countries. See in particular the estimates constructed by Davies et al (2011, 2010-2016) published in "Credit Suisse" Global Wealth Reports. Unfortunately, these works are not entirely explicit about what they mean by "Pareto interpolation" (they do not provide on-line computer codes, and we were not able to determine how exactly they compute their top wealth share estimates). As shown by Blanchet, Fournier and Piketty (2017), existing distributions of income and wealth are better characterized by "Pareto curves" (i.e. by a non-parametric curve of Pareto coefficients) than by a single Pareto coefficient. This also explains why it is unfortunately not sufficient to have billionaire data in order to infer top wealth shares with reasonable precision. All detailed estimates and computer codes are available on-line.

${ }^{16}$ Full details are provided in the on-line appendix. Using national accounts series, we estimate that tax-exempt capital income gradually rises from $1 \%$ of fiscal income in 1990 to $10 \%$ in 2000 and then stabilizes at this level.

${ }^{17}$ See Appendix B, Figure B30-B31.
} 


\section{Section 3. The Rise of Private Property in Russia}

In this section we present our main results regarding the evolution of aggregate private and public wealth in Russia since the fall of the Soviet Union. The first major change that occurred between 1990 and 2015 is of course the transition from communism to capitalism, i.e., from public to private property.

Section 3.1. The general evolution of national, public and private wealth

According to our benchmark estimates (see Figure 4), net national wealth amounted to slightly more than $400 \%$ of national income in 1990, including about $300 \%$ for net public wealth (roughly three quarters) and little more than $100 \%$ for net private wealth (one quarter). In 2015, the proportions are basically reversed: net national wealth amounts to $450 \%$ of national income, including more than $350 \%$ for net private wealth and less than $100 \%$ for net public wealth. The dramatic fall in net public wealth happened in a couple of years only, between 1991 and 1995, following the socalled shock therapy and voucher privatization strategy. ${ }^{18}$

It is also worth noting that aggregate national wealth first fell relatively to national income between 1990 and 1999, from over $400 \%$ of national income to about $300 \%$, i.e., aggregate national wealth fell even more than national income. It then rose very significantly between 1999 and 2008-2009, reaching about 550\% of national income. This peak corresponds to a very large rise of Russian stock market prices and housing prices during this decade. Asset prices fell in the aftermath of the financial crisis, and aggregate national wealth is back to about $450 \%$ of national income in 2015 , a level that is only slightly higher than in 1990. The major transformation during the $1990-2015$ is the shift from public to private property, while the aggregate value of national wealth has remained roughly constant.

In order to better understand the processes at work, it is critical to look separately at the different asset categories. We start with the rise of private wealth (see Figure 4).

\footnotetext{
${ }^{18}$ One key argument behind the shock therapy doctrine was that rapid privatization would prevent any possible return to public property and communism. See, e.g., Boycko, Shleifer and Vishny (1995).
} 
One key finding is the critical role played by housing. Other domestic capital (mostly consisting of unincorporated businesses owned directly by households) and agricultural land (which was also largely privatized during the 1990s) increased over time, but these assets played a relatively limited role as compared to the rise of private housing, which increased from less than $50 \%$ of national income in 1990 to $250 \%$ of national income in 2008-2009 (at the peak of the housing bubble), down to about $200 \%$ of national income by 2015 . In addition to real estate price movements, the gradual rise of private housing between 1990 and 2015 can be accounted for by the fact that housing privatization happened in a more continuous manner than the voucher privatization method used for companies. Tenants were given the right to transfer the housing unit into their ownership free of charge,$^{19}$ but they did not need to exercise this right immediately. Due to various economic, political and psychological factors, many Russian households waited until the late 1990s and even the 2000 s to exercise this right. $^{20}$

What is particularly striking is the very low level of recorded financial assets owned by Russian households (as measured by official Rosbank financial balance sheets). Household financial assets have always been less than $70-80 \%$ of national income throughout the 1990-2015 period, and they have often been less than $50 \%$ of national income (e.g. as little as $20-30 \%$ of national income in the late 1990 s and early 2000s). ${ }^{21}$

In effect, it is as if the privatization of Russian companies did not lead to any significant long-run rise in the value of household financial assets, in spite of the fact that it is now possible to own financial shares in Russian firms, which seems especially paradoxical.

\footnotetext{
${ }^{19}$ The 'free privatization' model was implemented in 1992 and it was accompanied by a remarkable rise in the number of privatized dwellings (Kosareva et al 2000, p. 155). See Appendix A for the evolution of the housing privatization.

${ }^{20}$ Some were concerned about the possible maintenance costs associated to private ownership (while under public housing ownership maintenance work was taken care of by public authorities). Others were concerned about a possible political downturn (the presidential election of 1996 was won by Yeltsin with a 54\% margin against communist party leader Zyuganov).

${ }^{21}$ Household debt (which is relatively small in Russia - less than $20 \%$ of national income) was deducted from housing values on the series reported on Figure 4, so net financial assets would be even smaller. See Appendix A for all details on sources and computations.
} 
The initial decline in financial assets was predictable. Back in 1990, household financial assets (which at the time mostly consisted of saving accounts) amounted to about $70-80 \%$ of national income. Unsurprisingly, these Soviet-era savings were literally wiped out by the hyper-inflation of the early 1990s. The consumer price index was multiplied by nearly 5000 between 1990 and 1996, with annual inflation rates of the order of $150 \%$ in $1991,1500 \%$ in $1992,900 \%$ in $1993,300 \%$ in 1994 and $150 \%$ in 1995. The new ruble - worth 1000 old rubles - was introduced in 1998, and inflation stabilized at about 20-30\% per year on average between 1996 and 2006. Given the enormous inflation of the 1991-1995 period, Soviet-era savings were worth close to nothing by the late 1990 s.

What is more surprising is why the new financial assets that were accumulated by Russian households during the 1990s - in particular through voucher privatization did not compensate for this loss. Of course, when vouchers were first introduced in 1992-1993, it was very difficult for Russian households to know what to do with these new financial instruments and to put a price on them. More generally, one can argue that in the chaotic monetary and political context of the 1990s it is not too surprising that the market value of household financial assets remained relatively low until the mid to late 1990s. What is more difficult to understand is why such extremely low valuations persisted well after. In particular, in spite of the spectacular Russian stock market boom that occurred between 1998 and 2008, it is striking to see that total financial assets recorded as owned by Russian households amounted to little more than $70 \%$ of national income in 2008, i.e. less than the level observed in 1990 .

In our view, the main explanation for this paradox is the fact that a small subset of Russian households own very substantial offshore wealth, i.e., unrecorded financial assets in offshore centers. According to our benchmark estimates, offshore wealth has gradually increased between 1990 and 2015, and represents about $85 \%$ of national income by 2015 , i.e., roughly as much as the recorded financial assets of Russian households (see Figure 4). By definition, offshore assets are difficult to estimate, and we certainly do not pretend that our benchmark estimates are perfectly precise. But the orders of magnitude seem to be reasonable, and if anything may be somewhat under-estimated. We now turn to a more detailed presentation of the construction of these offshore wealth estimates. 
Section 3.2. Estimating capital flight and offshore wealth in Russia

In order to estimate the rise and magnitude of offshore wealth held by Russian households, it is natural to start by looking at the evolution of Russia's trade balance and balance of payments. Here the striking fact is the contrast between the very large trade surpluses and the relatively modest foreign assets (see Figure 5a).

Russia has run large trade surpluses every single year since the early 1990s. These trade surpluses - mostly driven by exports in oil and gas - have been around $5 \%$ of national income per year between 1993 and 1998, up to as much as $20 \%$ of national income in 1999-2000, and have stabilized around $10 \%$ of national income per year between 2001 and 2015. Over the 1993-2015 period, the average trade surplus neared $10 \%$ of national income per year $(9.8 \%)$. In other words, every year during more than 20 years, the Russian economy has been exporting about $10 \%$ of its annual output in excess to what it has been importing. Given that the initial financial position of the country was close to zero in 1990 (very little foreign assets, very little foreign debt), this should have led to a massive accumulation of foreign assets by Russian residents (government, households and corporations). The paradox is that net foreign assets accumulated by Russia are surprisingly small: about $25 \%$ of national income by 2015 (see Figure 5a).

If one looks in more detail at Russia's balance sheet vis-à-vis the rest of the world, we find that both foreign assets (i.e., assets owned by Russian residents in the rest of the world) and foreign liabilities (i.e., assets owned by rest-of-the-world residents in Russia) have increased significantly since the fall of the Soviet Union. Both were extremely small in 1990 (about 10\% of national income), reflecting low levels of financial integration with the rest of the world and strong capital controls. By 2015, foreign assets reached almost $110 \%$ of national income, and foreign liabilities were close to $85 \%$ of national income, hence the net foreign asset position was about $25 \%$ of national income.

How can we account for such a low level of net foreign wealth accumulation? The obvious explanation is capital flight: some Russian individuals (and/or some Russian 
corporations acting on behalf of individuals, and/or some Russian government officials acting on behalf of individuals) were somehow able to appropriate some of the trade surpluses in order to accumulate offshore wealth, i.e. foreign assets that are not properly recorded as such in Russia's official financial statistics. Given the weaknesses of Russia's legal and statistical system, and the widespread use of offshore entities to organize business and financial transactions in Russia over this period (see, e.g., the work by legal experts such as Nougayrede 2014, 2015, 2017), it is maybe not too surprising that such leakages might have occurred.

How large is the corresponding capital flight and associated offshore wealth? If we simply cumulate the trade surpluses over the 1990-2015 period, we obtain about $230 \%$ of national income. So one might conclude that cumulated capital flight is of the order of $200 \%$ of national income (given that official net foreign assets are less than $30 \%$ of national income). In principle, one should also include the cumulated capital income flow on these foreign assets, which depending on the rate of return could lead to substantially larger estimates for missing foreign wealth (with a total around $300 \%$ of today's Russia national income, or more, depending on the return). The key question is: where has this missing wealth gone, and how can we reconcile the different pieces of evidence and explanation?

First, one should take into account the fact that the flow return earned on foreign assets might be lower than the flow return paid on foreign liabilities. This is indeed what the balance of payment of Russia indicates: we observe persistently negative net foreign income flow throughout the 1990-2015 period (about $-3 \%$ of national income), in spite the generally positive net foreign asset position (see Figure 5a). In effect, a significant part of the annual trade surplus - between one quarter and one third - has been absorbed by this net capital income outflow. It is possible that this reported return differential also reflects some forms of capital flight, but we have no precise way to know.

Next, one should take into account the capital gains and losses realized on the portfolio of foreign assets and liabilities. Such valuation effects could potentially be enormous and account for the observed discrepancy between annual current account surpluses and the observed evolution of net foreign assets. That is, if all 
Russian investments abroad ended up in worthless assets (capital losses), while all foreign investments in Russia benefited from huge increases in value (capital gains), then one could in principle explain why Russia's net foreign assets are so small. Indeed this is partly what has happened: foreign investors bought Russian assets in the 1990s when stock market prices were extremely low and benefited from the booming stock market of the 2000s. This partly explains why foreign liabilities rose so much (see Figure 5b).

However, the return differential and valuation effects are not large enough to entirely explain the discrepancy between the cumulated trade surpluses and the change in the net foreign asset position. In order to estimate the magnitude of offshore wealth (missing foreign assets), we apply the following method. We take as given the observed differential in rates of return and capital gains and losses on foreign assets and liabilities, and we compute the sum of net errors and omissions and "fictitious transactions" in the balance of payments. Net error and omissions reflect unrecorded saving: they correspond to the gap between the current (plus capital) account balance and recorded net foreign saving. ${ }^{22}$ Fictitious transactions are the official estimates by the Bank of Russia of the fake "trade in goods and services, securities trading, and lending to nonresidents whose purpose is cross-border money transfers." In particular, fictitious transfers include exports misinvoicing, whereby Russian exporters, for instance, under-report to customs authorities the value of the goods and services they export, and the difference between the real value of the export and the value reported to the authorities is paid to the exporters' offshore account. The sum of net error and omissions and fictitious transactions is our estimate of annual capital flight. We then cumulate yearly capital flight making various assumptions on the rate of return and we obtain the benchmark estimates and lower and upper variants reported on Figure $5 c^{23}$

\footnotetext{
${ }^{22}$ For instance, in 2010 Russia has a current account surplus of $\$ 67$ billion, a capital account balance of $\$ 0$, and yet its recorded foreign saving flow is only $\$ 58$ billion instead of $\$ 67$ billion. That is, there are $\$ 9$ billion of net errors and omissions (either under-estimated Russian investment flows abroad, or over-estimated foreign investment flows in Russia).

${ }^{23}$ In our benchmark scenario, we assume that offshore wealth earns an annual rate of return which is equal to the growth rate $\mathrm{g}$ of the Russian economy, i.e., we assume that offshore wealth grows just like the Russian economy. In our lower bound scenario, we assume that offshore wealth grows at rate $\mathrm{g}-2 \%$ (this corresponds to a scenario where offshore wealth is consumed at a relatively fast rate). In our upper bound scenario, we assume that offshore wealth grows at rate $g+2 \%$. All details are provided in Appendix A.
} 
According to our benchmark estimates, offshore wealth reaches about $85 \%$ of national income by 2015 (vs. about 100\% in the upper-bound variant and $55 \%$ in the lower-bound variant). These estimates are by construction relatively conservative: we take as given the differential in returns and portfolio effects, which may also reflect some form of capital flight and accounting manipulation by foreign investors or by Russian nationals or ex-nationals. Our benchmark estimates suggest that Russians own approximately as much financial wealth offshore as onshore, i.e. they own about $50 \%$ of their true total financial wealth offshore. This is the same estimate obtained by Zucman (2014) using a different approach, which can be viewed as reassuring. ${ }^{24}$

We should stress again, however, that the frontiers between the different forms of missing wealth are highly uncertain and difficult to estimate with absolute precision, given the general lack of international financial transparency. What we know for sure is that the magnitude of cumulated Russian trade surpluses and total missing wealth over the $1990-2015$ is extremely large (at least $200 \%$ of Russia's national income). It is more complicated to know who holds the missing wealth and the form it takes.

At a general level, one can distinguish between three different categories of beneficiaries: first, there are pure foreigners (individuals or corporations with no initial tie to Russia), who accumulated wealth by doing business in Russia since the 1990s via differential rates of return and valuation effects (these foreigners might now hold the corresponding wealth in Russia or elsewhere, or might have consumed it; in some cases, this mechanism might have also benefited Russian nationals or exnationals). Next, there are Russian nationals (or ex-Russian nationals) who are now foreign residents, and who were able to divert assets via offshore transactions. Last, there are Russian nationals who still have their primary residence in Russia, and who were able to divert assets via offshore transactions.

\footnotetext{
${ }^{24}$ Namely, the estimate in Zucman (2014) relies on statistics on the bank deposits owned by Russian residents in offshore centers (Switzerland, Luxembourg, United Kingdom, etc.) which are published through the Bank for International Settlements (BIS). See Zucman $(2013,2014,2015)$ for more details. Note however that the overall Russian asset levels reported by Zucman (2014) are lower than those reported here, partly because the former only capture financial assets (and excludes real foreign assets), and partly because our new estimate is broader in scope, as it includes wealth that belongs to non-residents (emigrants) on top of offshore assets belonging to residents. See the discussion below.
} 
Our estimates of offshore wealth can be viewed as the sum of the last two components. We do not attempt to provide a formal breakdown between them, i.e., between Russian residents and non-residents. According to balance-of-payments statistics, capital transfers represent less than $10 \%$ of total net errors and omissions and capital transfers, so one might be tempted to conclude that Russian residents are the primary holders. This would also be consistent with the global Forbes billionaire data, according to which the vast majority of Russian billionaires have their primary residence in Russia (see section 2 and Figure 2). ${ }^{25}$

Even more uncertain is the nature of the destination assets: some of the offshore wealth might be invested back in Russian corporations, and some might be invested abroad (e.g., a mansion in London, a castle in France, or a company in Germany, the U.S. or elsewhere) ${ }^{26}$ By inspecting the list of Russian billionaires released by Forbes (which together own more than 400 billion dollars in assets), and the information about the corresponding wealth portfolios published in Forbes and other magazines, one may be tempted to conclude that most of the offshore wealth is held in Russian companies (in particular in the energy and financial sectors). On this basis, our preferred interpretation of available data is that a large fraction of Russia's official foreign liabilities (over $80 \%$ of national income in 2015 - see Figure 5b) is actually held by Russian residents via offshore accounts. Given that the Forbes list does not provide any information regarding the fraction of reported billionaire wealth held offshore (we suspect this is a very large fraction, but we do not know), it is difficult to go further.

\section{Section 3.3. Market-value vs book-value national wealth}

We now come to the evolution of the composition of aggregate national wealth (both public and private) in Russia over the 1990-2015 period. So far we focused on market-value national wealth. That is, corporate assets were valued at prevailing stock market prices.

\footnotetext{
${ }^{25}$ Note that the notion of primary residence used by Forbes is not entirely clear, and may not coincide with the notion used by Russian tax administration or other legal definitions.

${ }^{26}$ Note that according to SNA Guidelines real assets owned in other countries are treated as financial assets owned in a foreign corporation (which then owns the domestic real assets).
} 
This explains a large part of the fluctuations in the ratio between market-value national wealth and national income reported in Figure 6a: the value of other domestic capital (which includes the value of corporate capital and other non-housing non-agricultural-land domestic capital) is very small in the late 1990s-early 2000s because of the low stock market valuation of Russian companies. In contrast, market-value national wealth reaches much higher levels in 2008-2009 due to high corporate and housing valuations (see Figure 6a).

Another, complementary viewpoint on national wealth consists of looking at bookvalue national wealth. That is, the value of corporations is defined as the difference between the value of their non-financial and financial assets and the value of their financial non-equity liabilities (see section 2 above). If we apply this definition, we find that the levels of other domestic capital and total national wealth are much less volatile (see Figure 6b). In effect, this is taking away stock market fluctuations.

It is also worth noting that book-value national wealth is systematically larger than market-value national wealth in Russia. In other words, Tobin's $Q$ ratio, i.e. the ratio between market (equity) value and book value is always less than one, including at the peak of the stock market boom in 2008.

It is worth pointing out that there are very different ways to interpret the fact that Tobin's $Q$ is systematically below one. There are many countries with well-functioning legal systems where $Q$ ratios are systematically below one, such as Germany, Nordic countries or Japan (see Piketty and Zucman, 2014). The standard explanation is the stakeholder model: various actors other than shareholders, including worker representatives and sometime regional government, share corporate decisionmarking power, which may reduce the market value of equity shares, but not necessarily the social value of companies. Of course, one can also think of less optimistic interpretation of low $Q$ ratios, which may better fit the Russian case, such as ill-defined property rights and low protection of shareholder stakes in companies (not the benefit of other well-defined and potentially efficiency-enhancing stakeholders, but simply because the legal system is not working well). 
An additional reason for less than one Tobin's $Q$ in Russia could be due to the low market valuation of the capital inherited from the Soviet era. The story of the overextended and uncompetitive Soviet industry is quite well known. But inherited capital still accounts for the important part of the Russian capital stock and many industries have been artificially kept alive as a part of the government social policy. To some extent, this explanation is complementary to the above mentioned, since government can reduce shareholders' control in most profitable sectors, such as natural resources, as a part of the wider rent-sharing system (Gaddy and Ickes 2002; Gustafson 2012).

Finally, it could also be that this low level of market valuation reflects the importance of offshore assets and legal outsourcing in the management and control of Russian corporations. That is, one additional reason why the market value of equity shares traded on the Russian stock market is relatively low might be that Russian corporations are embedded into a complex nexus of contracts and offshore legal entities, of which the system of official shares ruled by the Russian legal system and traded on Moscow stock market is only the visible part. Some of the case-based evidence reported by legal scholars such as Nougayrede $(2014,2015,2017)$ seems consistent with this interpretation. More research is needed to analyze these issues.

\section{Section 3.4. Comparison with Western and other ex-communist countries}

We now compare our findings regarding the evolution of aggregate wealth in Russia to the evolution observed in other countries. Consider first the evolution of private wealth-national income ratios. It is by now well-known that there has been a general rise of private wealth relative to national income in all developed countries since the 1970s-1980s (Piketty and Zucman 2014; Piketty 2014). This evolution can be attributed to a mixture of factors, including a combination of growth slowdown and relatively high saving rates (leading to high wealth-income ratios, partly in relation to ageing), as well as a general rise of the relative price of housing and financial assets relative to the consumer price index, reflecting a complex set of institutional and possibly technological changes (including financial deregulation, the end of rent control, rising agglomeration effects, and relatively slow technical progress in construction and transportation as compared to other sectors). 
The case of Russia - together with that of China and other ex-communist countries can be viewed as an extreme case of this general evolution, reflecting another critical explanatory factor, namely the privatization of public assets. In Russia as in China, private wealth was very limited back in 1980: slightly more than $100 \%$ of national income in both countries according to our estimates. By 2015, private wealth has reached $500 \%$ of national income in China, i.e. approximatively the same level as in the U.S., and rapidly approaching the levels observed in countries like France or Britain (550-600\%). In Russia, private wealth has also increased enormously relative to national income, but the ratio is "only" of the order of $350-400 \%$ in 2015 , i.e. at a markedly lower level than in China and in Western countries (see Figure 7a). We should stress that the gap would be even larger if we did not include our estimates of offshore wealth in Russia's private wealth. ${ }^{27}$

Moreover, the rise of Russian private wealth has been almost exclusively at the expense of public wealth, in the sense that national wealth - the sum of private and public wealth - almost did not increase relative to national income (from $400 \%$ in 1990 to $450 \%$ by 2015). In contrast, China's national wealth has reached $700 \%$ of national income by 2015 (see Figure 7b).

The widely divergent patterns of national wealth accumulation observed in Russia and China can be accounted for by a number of factors. First, saving rates have been markedly higher in China - typically as large as $30-35 \%$, vs $15-20 \%$ at most in Russia (net of depreciation). If a country saves more, it is bound to accumulate more wealth.

Next, Chinese savings were used for the most part to finance domestic investment and hence domestic capital accumulation in China. In contrast, a very large fraction typically about half - Russia's national saving were in effect used to finance foreign investment (via very large trade surpluses and current account surpluses) rather than domestic investment. This is not necessarily bad in itself, except that as we have

\footnotetext{
${ }^{27}$ For other countries, offshore wealth is estimated to be much smaller than in Russia (typically less than $10 \%$ of national income; see Zucman 2014) and is not included in the estimates reported here. Note however that offshore wealth held by Chinese has been increasing fast in recent years and might become more significant over time. We plan to further investigate this issue in future research.
} 
seen earlier these large flows of foreign savings did not result into much wealth accumulation, due to general mismanagement of the surpluses (bad portfolio investment, capital flight and offshore leakages). Again, the gap between Russia and China would be even larger if we did not include offshore wealth in Russian national wealth (as we do throughout this paper and on figure $7 \mathrm{~b}$, which is obviously debatable, given that offshore wealth is largely out of reach of Russia's national government). In contrast, if we were to include the full value of cumulated trade surpluses in Russia's national wealth, then Russia's national wealth-income ratio would be at the same level as China by 2015 (around $700 \%$ of national income). This illustrates the macroeconomic significance of this issue.

Finally, another reason why China's national wealth income ratios are higher than in Russia is because relative asset prices have increased more. In particular, Tobin's $Q$ ratios are much closer to one in China (see Piketty, Yang and Zucman 2017 for detailed volume-price decompositions of China's wealth accumulation). The interpretation of this finding might reflect different factors (including more organized stake-holders in Russia, and/or less well protected property rights, and/or more legal outsourcing; see the discussion in previous subsection).

It is also interesting to compare the evolution of the overall share of public property in Russia and other countries (see Figure 7c). In developed countries, the share of net public wealth in net national wealth was significantly positive in the post-WW2 decades up until about 1980 , around $15-25 \%$ of national wealth, reflecting low public debt and significant public assets (including corporate assets in manufacturing and finance in several Western countries). Net public wealth declined significantly since the 1980s, due both to the rise of public debt and the privatization of public assets. By 2015 net public wealth has turned negative in Britain, Japan and the U.S. (and is barely positive in Germany and France). In effect this means that private wealth holders own the equivalent of total public assets (via financial intermediation and the ownership of public debt), and also a fraction of future tax payments (in countries with negative net public wealth).

Ex-communist countries like Russia, China and the Czech Republic (also represented on Figure $7 \mathrm{c}$ ) have followed the same general pattern as developed 
countries in recent decades - namely a declining share of public property - but starting from a much higher level of public wealth. In these three ex-communist countries, the share of net public wealth was as large as $70-80 \%$ in 1980 , and falls between 20\% (Russia) and 30-35\% (China and the Czech Republic) in 2015, ${ }^{28}$ i.e. a level that is higher but not incomparable to that observed in "capitalist" countries during the "mixed economy" period (1950-1980). In other words, these countries have ceased to be communist, in the sense that public ownership has ceased to be the dominant form of property, but they still have much more significant public wealth than other capitalist countries. ${ }^{29}$ This is due both to low public debt and significant public assets (including in Russia in the energy sector). There are also strong differences between these countries. In particular, the privatization process was much more gradual in China than in Russia: it started earlier, and is still going on (although Chinese authorities might also choose to stabilize the public-private divide at the current level). The gradual privatization pattern observed in the Czech Republic is intermediate between the two, and is in some ways closer to China (see Figure 7c). From that viewpoint, the "big bang", "shock therapy" approach followed for privatizing Russia appears to be markedly different from that followed in other excommunist countries (something that we will later relate to the different inequality trajectories). It would be very interesting to compare these patterns to other Eastern European countries, but unfortunately comprehensive balance sheets are yet to be collected for most of these countries.

Finally, it is interesting to compare ex-communist countries with respect to the importance of foreign assets (see Figure 7d). It is particularly striking to contrast the case of Russia and China, which both have positive net foreign assets (i.e. these two countries own more assets in the rest of the world than what foreigners own in Russia and China), and Eastern European countries, which all have hugely negative

\footnotetext{
${ }^{28}$ However, we should note here that a relatively higher share of the public wealth in the national wealth observed in the Czech Republic, equivalent to $30-35 \%$, is not entirely representative for former communist countries in Eastern Europe. The Czech Republic displays unusually high ratio of public non-financial produced assets (or broadly the public infrastructure) to national income. In the ongoing work we document lower public infrastructure to national income ratio in most other ex-communist countries, such as Hungary or Slovenia, so public wealth generally accounts today for smaller share in the national wealth in Eastern Europe. See Appendix A for more details.

${ }^{29}$ Throughout this paper we refer to China as an " ex-communist country ", in the obvious sense that public ownership has ceased to be the dominant form of ownership, and notwithstanding the fact that China's Communist Party is still ruling the country.
} 
net foreign assets (i.e. these are largely foreign-owned countries). These differences are partly due to differences in economic and natural endowments. In particular, it makes sense for countries with large (but not permanent) natural resources such as Russia to accumulate trade surpluses and foreign reserves for the future. This is what one observes in most oil-rich countries in the Middle East and elsewhere.

But differences in political institutions and ideologies seem to play an even bigger role than purely economic factors. As we have already and repeatedly stressed, Russia has been unable to accumulate large foreign assets, in spite of the equivalent of over $200 \%$ of national income in cumulated trade surpluses over the 1990-2015 period. In contrast, an oil-rich country like Norway, with comparable trade surpluses (around $10 \%$ of its national income per year over this period) accumulated a very large sovereign fund (see Figure 7f).

It is also striking to see that China has accumulated net foreign assets that are similar in magnitude to those of Russia (see Figure 7d), in the absence of any significant natural resource endowment, and with much smaller trade surpluses (less than $3 \%$ of national income on average over the 1990-2015 period). This reflects more efficient management of trade surpluses and foreign reserves (which are viewed as critical for the country's economic and financial sovereignty by the CPC), and also a political choice of limiting foreign investors' rights in China.

Finally, the large negative foreign asset positions of Eastern European countries should obviously be put in relation to the fact that these countries have adopted a development strategy based upon economic and political integration within the European Union. Eastern European countries are largely foreign-owned, but the owners tend to come from EU countries (in particular from Germany). So in some sense it is not entirely different from the situation of peripheral regions that are being owned by more prosperous central regions in a large federal country.

It is also worth noting that these patterns of foreign ownership also have consequences for the study of domestic inequality. In particular, as demonstrated by Novokmet (2017), the fact the holders of top capital incomes tend to be foreigners rather than domestic residents contributes to lower top income shares in countries 
like the Czech Republic or Poland or Hungary (as compared to countries like Russia or Germany). I.e. foreign owned countries tend to have less domestic inequality (other things equal). We will return to this when we compare inequality trends across countries.

Finally, note that a significant subset of Eastern European countries (in particular Poland, Hungary and Bulgaria) already had large negative net foreign asset positions back in 1990 (see Figure 7e). Here the pattern has been mostly one of change in the identity of the foreign owner (from Russia to Germany, to a large extent).

\section{Section 4. The Rise of Income and Wealth Inequality in Russia}

We now present our results regarding the evolution of income and wealth inequality in Russia. We begin with income inequality and the very long-run trends, before moving to a closer analysis of the recent decades, comparison with other countries, and finally wealth inequality.

Section 4.1. Income Inequality: the Long-Run Picture

Our general results on the long-run evolution of inequality in Russia over the 19052015 period are summarized on Figures $8 \mathrm{a}-8 \mathrm{~b}$. The basic picture is pretty obvious: income inequality was high under Tsarist Russia, then dropped to very low levels during the Soviet period, and finally rose back to very high levels after the fall of the Soviet Union. According to our benchmark estimates, the top 10\% income share was about $45-50 \%$ in 1905 , dropped to around $20-25 \%$ during the Soviet period, and rose again to $45-50 \%$ in the 1990 s before stabilizing at this very high level since then (see Figure $8 a$ ). The top $1 \%$ income share was somewhat below $20 \%$ in 1905, dropped to as little as $4-5 \%$ during the Soviet period, and rose spectacularly to $20-25 \%$ in the recent decades (see Figure 8b).

Several remarks are in order. First, these broad orders of magnitude can be considered as reliable, but small variations should not be taken too literally, given the strong limitations of our data sources. In particular, our benchmark estimates suggest that inequality levels in Tsarist and post-Soviet Russia are roughly comparable. Very 
top income shares seem if anything somewhat larger in post-Soviet Russia. One can interpret this finding as showing that modern economic and financial technologies (including international oil markets and offshore wealth) are able to generate more extreme monetary inequality than traditional societies like Imperial Russia. One could also argue that extreme inequality is maybe less dramatic (and more acceptable) when average living standards are much higher.

However we should also make clear that the differences between the two periods may not be fully significant, first because the lack of detailed income tax data - and the general lack of financial transparency - make our estimates for the recent period relatively imprecise (we will later return on this); and next and most importantly, because the estimate for 1905 is at least as imprecise. It relies not on actual income tax data, which was never implemented in Tsarist Russia, but on income tax projections that were made by Imperial tax administration at the time the regime was considering the possibility to implement such a tax. Similar estimates were made in a similar context in other countries in the late $19^{\text {th }}$ and early $20^{\text {th }}$ centuries (e.g. in France), and the comparison between these projections and the actual income tax data generated by the application of the new fiscal system revealed that the tax administration was significantly underestimating top income levels (see Piketty, 2001). Of course we will never know what would have happened if an income tax had been implemented in Tsarist Russia, but there is a possibility that the same result would have prevailed. It seems safer to conclude that inequality levels in Tsarist and post-Soviet Russia are both very high - and roughly comparable, possibly with a somewhat higher level in the later period. ${ }^{30}$

Finally, it is worth stressing that the measures of monetary inequality depicted on Figures $8 \mathrm{a}-8 \mathrm{~b}$ obviously neglect non-monetary dimensions of inequality, which may biases comparisons of inequality over time and across societies. For instance, inequalities in personal status and basic rights (including mobility rights) were pervasive in Tsarist Russia, and persisted long after the official abolition of serfdom in

\footnotetext{
${ }^{30}$ Lindert and Nafziger (2012) argue that the 1905 official inequality estimate might be somewhat ovestimated. However on the basis of similar estimates done by tax administrations in other countries (such as France, see above), we tend to reach the opposite conclusion. In any case, the data seems too fragile to draw a definitive conclusion about the comparison between levels of monetary inequalities prevailing in 1905 and 2005-2015.
} 
1861. ${ }^{31}$ Summarizing such inequalities with a single monetary indicator is clearly an over-simplification of a complex set of power relations and social domination, and should be kept in mind when making historical and international comparisons.

The same general remark applies to the Soviet period. Monetary inequality was reduced to very low levels under Soviet communism (and also in other communist experiences, as we shall later see). For instance, a top 1\% income share around 4$5 \%$ means that top $1 \%$ income holders earn only $4-5$ times the average income of the time, as compared to 20 times when the top $1 \%$ share is equal to $20 \%$. This reluctance to rely on extended monetary hierarchies is a feature that is confirmed by all Soviet household surveys and administrative documents on salary scales. In addition, the Soviet regime abolished private ownership (except in some cases for small capital holdings) and therefore suppressed top capital incomes (which in other societies always represent a large fraction of top incomes). It also compressed very significantly the hierarchy of salaries and labor incomes.

However this obviously does not mean that the Soviet elite did not have access to superior goods, services and opportunities. ${ }^{32}$ This could take different forms - access to special shops, vacation facilities, etc. - which in effect could allow the Soviet top $1 \%$ to enjoy living standards that in some cases might have been substantially higher than 4-5 times average incomes (though probably quite a bit lower than under Tsarist or in post-Soviet Russia). Unfortunately we have no way to quantify this.

Finally, it is worth pointing out that although monetary inequality has been very low throughout the Soviet period, there are interesting medium term variations. Namely, we observe a very strong compression of the distribution of income during the first

\footnotetext{
${ }^{31}$ For instance, according to the 1861 reform, the serfs were made responsible for compensation to landlords for loss of labor, with "redemption payments" to be made annually for 49 years (this resembles the compensation that Haiti had to pay to its former French slave-owners in order to obtain independence). These payments were later renegotiated, with extensive regional and local variations, but the general point is that the abolition of serfdom was a very gradual process, which in some cases reinforced the rights of landlords (rather the rights of ex-serves). In particular, there is ample evidence that landlords retained for several decades extensive coercion power to restrict the mobility rights of peasants (who were subject to a specific legal status and court system based upon unwritten "customary law" and largely controlled by local elites). See Denison (2014).
}

${ }^{32}$ See Matthews (1978) for the most comprehensive attempt at delineating the Soviet elites. 
stage of the Revolution (resulting into a large inequality decline between 1905 and 1925), followed by a relative enlargement of income hierarchies between 1925 and 1956 during the Stalinist period, a gradual decline between 1956 and 1980, and a rise during the 1980s and at the beginning of the economic reforms. This periodization has already been noted by other scholars exploiting Soviet sources on the distribution of income and wages (see e.g. Atkinson and Micklewright 1992).

\section{Section 4.2. Who Benefited from Post-Soviet Transition?}

We now look into more details at the recent period. First, it is striking to see that the rise in income inequality occurred very fast after the fall of the Soviet Union. According to our benchmark estimates, the top $10 \%$ income share rose from less than $25 \%$ in $1990-1991$ to more than $45 \%$ in 1996 (see Figure 8 a).

It is also worth pointing out that this enormous rise came together with a massive collapse of the bottom $50 \%$ share, which dropped from about $30 \%$ of total income in $1990-1991$ to less than $10 \%$ in 1996, before gradually returning to $15 \%$ by 1998 and about $18 \%$ by 2015 (see Figure $8 c$ ). There is no doubt that hyper-inflation played a key instrumental role in the collapse of bottom incomes. Between 1990 and 1996, prices were multiplied by a factor of nearly 5000 (see section 3 and Appendix A). Inflation was particularly high in 1992-1993 after official price liberalization occurred on January $1^{\text {st }} 1992$. A large part of bottom $50 \%$ income classes were made up of pensioners and low-wage workers whose nominal incomes were not fully indexed to price inflation, resulting into massive redistribution and impoverishment for dozens of millions of Russians households (particularly among the retired population). Low-end pensions and wages then benefited from a gradual recovery process between 1996 and 2015 , but they never fully returned to their 1990-1991 relative income share.

Together with this process of rapid collapse and partial recovery for bottom income groups, we observe a more gradual and continuous process of rising top $1 \%$ income shares, from less than $6 \%$ in 1989 to about $16 \%$ in 1996 and over $26 \%$ in 2008 . The top $1 \%$ share then dropped in the aftermath of the 2008-2009 financial crisis and stabilized around $20-22 \%$ since 2010 (see Figure 8 a). 
If we consider the period 1989-2016 as a whole, average per adult national income has increased by $41 \%$ according to our benchmark estimates, i.e. at about $1.3 \%$ per year. However the different income groups have enjoyed widely different growth experiences. The bottom 50\% earners benefited from very small or negative growth, the middle $40 \%$ from positive but relatively modest growth, and the top $10 \%$ from very large growth rates (see Tables 1-2 and Figure 9a). From that viewpoint, the 1989-2016 looks very different from the 1905-1956 period, when most of the growth went to the bottom $90 \%$, and also from the 1956-1989 period, when the distribution was approximately constant and growth was relatively balanced over all groups (see Table 3 and Figure 9b). ${ }^{33}$

The fact that the growth incidence curve over the 1989-1996 period displays a strong upward-sloping profile is fully consistent with recent findings presented in the 2016 EBRD report on inequality dynamics in transition economies. ${ }^{34}$ There are two differences, however. First, the growth incidence curve reported on Figure 9a is even more strongly tilted toward top incomes than the one presented in the EBRD report. This is because we use corrected inequality series combining survey data with income tax data and wealth data, while the EBRD growth incidence curve relies solely on self-reported survey data. Next, the EBRD report uses a different income concept that we do and comes with a higher cumulated growth of average income over the $1989-2016$ (i.e. about $+70 \%$ instead of $+41 \%$ ). We think it is preferable to use per adult national income (as we do), and we recognize that it is very difficult to compare real incomes for the Soviet and post-Soviet periods in a satisfactory manner. E.g. if we were to evaluate the welfare costs of shortages and queuing in 1989-1990, then it is possible that our aggregate growth figures might jump from $+41 \%$ to $+70 \%$ or more. ${ }^{35}$ More generally, we should make clear that there is little doubt in our view that the welfare of the vast majority of the population has improved since the end of Communism. The interesting question is whether they could have

\footnotetext{
${ }^{33}$ See Appendix B, Figures B13 to B17 for detailed growth incidence curves by sub-period.

34 See EBRD (2016, Chart 1.3, p.12).

${ }^{35}$ See Appendix A for a detailed discussion of alternative Russian growth series. One reason why the EBRD report comes with higher cumulated real growth estimates over the 1989-2016 is because they look at household income, whose share in GDP and national income was unusually small in 19891990. However to the extent that other components of national income also ultimately benefit to households it seems more justified to look at national income rather than household income.
} 
improved even more and in a more balanced and egalitarian manner with different policies and a different inequality trajectory.

We should also point out that the income-tax-data correction plays a much bigger role than the wealth-data correction in our corrected inequality estimates (see Figures $10 \mathrm{a}-10 \mathrm{~b})$. This reflects the fact that the income tax tabulations include a significant number of declarations very high business and capital income flows. This is also reinsuring, in the sense that the data available for the wealth correction (namely Forbes billionaire data) is relatively limited and uncertain. In the Appendix, we provide detailed robustness checks and a number of alternative variant series for the income-tax-data corrections. In all variants, corrected inequality levels are substantially higher than raw survey levels, and stand relatively close in magnitude to our benchmark series (by international and historical standards). ${ }^{36}$

Finally, it is interesting to note that our corrected Gini coefficient reaches its peak value in 1996, due to the very low bottom $50 \%$ share measured for this year (see Figure 10c). This contrasts with top $10 \%$ and top $1 \%$ income share series, which reach their peak levels in 2007-2008 (see Figures 10a-10b). This illustrates the need to go beyond synthetic inequality estimates and to look separately at the different segments of the distribution.

\section{Section 4.3. International comparisons}

We now come to international comparisons. We first compare the long-run evolution of income inequality in Russia and Western countries (here we take the US and France as examples, France being relatively representative of the West European pattern). In a way, Russia appears like an extreme version of the long-run U-shaped pattern observed in the West during the $20^{\text {th }}$ century (see Figures $11 \mathrm{a}-11 \mathrm{~b}$ ).

At the beginning of the $20^{\text {th }}$ century, income inequality stood at very high levels pretty much everywhere, in Russia as well as in the US and France. Given the data limitations that we already discussed, it is difficult to make precise comparisons

\footnotetext{
${ }^{36}$ See in particular Appendix B, Figures B40-B42.
} 
between the inequality levels in the different countries around 1900-1910 (except that they were all very high). Available data suggests that top income shares stood at comparable levels in Russia and the US, and possibly at somewhat higher levels in France, but the observed gaps are not very large. Also if we take into account the non-monetary dimensions of inequality, including the limited rights of the rural poor in Russia, one can arguably conclude that inequality was higher in Russia.

During the 1917-1989 period, inequality stood at low levels everywhere, but the compression of inequality was particularly extreme in Russia. Previous research has stressed the role of political factors to account for the reduction of inequality in Western countries in the aftermath of the 1914-1945 political and military shocks: severe compression of top capital incomes following war destructions and the Great Depression; new policy regime with the rise of steeply progressive taxation of income and inherited wealth, the welfare state, and in some cases rent control and partial nationalization, with important variations across countries (see Atkinson and Piketty 2007, 2010; Piketty 2014). Russia illustrates an extreme form of political shock: the Soviet regime attempted to put an end to private property altogether, and to reduce monetary inequality to an extremely low level - indeed a level that had probably never been experimented before in human history.

Finally, in order to explain rising inequality in the West since the 1970s-1980s, with important variations across countries, previous research has again stressed the role of political factors and ideological reversals, including the conservative revolutions of the 1980s in the US and the UK, the rise of anti-progressive-tax movements, financial deregulation, and so on (Piketty, 2014). Here again Russia illustrates an extreme form of policy reversal: the system of public property was dismantled in a couple of years in 1991-1995, ultra-rapid voucher privatization and so-called "shock therapy" were implemented, and at the end of the process a flat tax system was put in place (with a $13 \%$ flat rate on top incomes which Reagan, Thatcher and Trump combined could not have dreamed of). Regardless of how one evaluates the desirability of these policies, this is clearly a policy reversal of enormous proportions.

Two further remarks are in order. First, the ideological shifts observed in the different parts of the world across the $20^{\text {th }}$ century clearly share some common origins, and 
have influenced one another. At a general level, the very high - and to some extent rising, or at least non-declining - inequality levels observed in the late $19^{\text {th }}$ and early $20^{\text {th }}$ centuries contributed to the rise of anti-free-market reactions pretty much everywhere. World War 1, the Great Depression and World War 2 strengthened the perception that laissez-faire capitalism was leading the world to chaos and needed to be regulated by stronger state policies. The Bolshevik Revolution also contributed to induce Western elites to accept policy changes which they largely refused until World War 1. In turn, the failure and final fall of the Soviet Regime in the late 1980s contributed to the pro-market ideological shifts.

Next, it is particularly interesting to compare the inequality trajectories followed by Russia and ex-communist countries. All Eastern European countries for which we have historical data - in particular Poland, the Czech Republic and Hungary - are characterized by high inequality levels in the early $20^{\text {th }}$ century and during the interwar period, low inequality during the communist period (1945-1990), and high and rising inequality since 1990 (see Figure 11c). Note that although all communist countries are characterized by unusually low levels of monetary inequality, there are interesting variations: inequality appears to be particularly low in the Czech Republic and Hungary, with top $1 \%$ income shares below $3 \%$, as opposed to $4-5 \%$ in Russia (and close to $6 \%$ at the end of the Stalinist period).

The fact that Soviet inequality was generally higher than under East European communist regimes has been noted by other researchers using historical survey and earnings data for communist countries during this period. In particular, this finding also applies to other dispersion indicators such as the P90/P10 ratio. We refer in particular to the work of Atkinson and Micklewright (1992), who stress that Russian inequality during the 1960s-1970s-1980s is in some ways intermediate between the East European level (Hungary, Poland, Czechoslovakia) and the British level, and who also find that gender inequality is substantially smaller in all communist countries (as compared to Britain and to other Western countries) during the 1960s-1970s, with 
a somewhat shrinking gap during the 1980s (unfortunately our data sources do not allow us to look at gender gaps in the long run in Russia). ${ }^{37}$

Regarding the recent period, it is striking to see that inequality has risen to much higher levels in Russia (with top 1\% income shares as high as 20-25\%) than in Eastern European countries (where top 1\% shares fall in the 10-14\% range the end of the period) (see Figure 11c). While our income tax data for Russia has many limitations (the income tax tabulations available for Eastern European countries are much more extensive and were recently exploited by Novokmet 2017), the gap with other ex-communist countries seems large enough to be significant. This is also consistent with the Forbes billionaire data showing an unusually large number of Russian billionaires since the 1990s-2000s, as compared to other ex-communist countries, and also as compared to other parts of the world.

While our data sources are too limited to provide a complete analysis of the inequality gap between Russia and other ex-communist countries, it seems natural to refer to the different post-communism transition strategies that were conducted in the different countries, and in particular to the very fast "shock therapy" and voucher privatization strategy that was conducted in Russia. A plausible interpretation of available data is that voucher privatization took place so fast, and within such a chaotic monetary and political context, that small groups of individuals were able to buy back large quantities of vouchers at relatively low prices, and also in some cases to obtain highly profitable deals with public authorities (e.g. via the famous loans-forshares agreements). ${ }^{38}$ Together with capital flight and the rise of offshore wealth, this process arguably led to much higher level of wealth and income concentration in Russia than in other ex-communist countries. As was mentioned above, the fact that

\footnotetext{
${ }^{37}$ See in particular Atkinson and Micklewright table 4.1 (p.81), table 4.2 (p.88), figure 4.7 (p.96) and table 5.1 (p.112). For some years, earnings inequality levels in the USSR (as measured by P90/P10 ratios or Gini coefficients) are actually very close to British levels.

${ }^{38} 40$ The critical divergence of top income shares trajectories in Russia and Eastern Europe from the mid-1990s may be related to the ownership consolidation in Russia (including in the natural resource sector) in the environment of legislative and institutional vacuum. Guriev and Rachinsky $(2006$, p. 7) have designated it as 'the institutional economies of scale', where "large owners were able to influence rules of the game from capturing regulators, courts and legislatures". On the other hand, it has been often argued that different institutional framework emerged in Eastern Europe - characterized by the higher rule of law, stronger protection of property rights, more successful building of market institutions, etc. - as a result of the prospective accession to the European Union (the so-called external anchor of EU accession; Berglof and Roland, 1997). See Roland (2017) on divergent evolution to China.
} 
a substantial part of the capital stock is owned by foreign wealth holders in Eastern European countries also contributes to lower inequality.

The data series that we have for China are unfortunately much shorter (they begin in 1978), but they also show that rising inequality is much stronger in Russia, while China seems to be closer in magnitude to the Eastern European pattern (see Figure 11d). According to our estimates, inequality was somewhat higher in China than in Russia in 1980 (due in particular to substantial urban-rural gap), and has now become substantially larger in Russia. This can be related to the fact that the privatization process was much more gradual in China, where public authorities still control the majority of corporations (see Piketty, Yang and Zucman 2017). This finding is again consistent with the Forbes billionaire data, showing a much higher level of billionaire wealth in Russia than in China (see section 2 above, Figure 2).

We certainly do not mean to suggest, however, that the only reason for higher top income shares in Russia is entirely due to different privatization strategies and resulting differences in today's property structure. While top capital and business incomes certainly play an important role (they probably constitute a large fraction of top-bracket taxpayers in Russia's income tax tabulations), it is very likely that higher inequality of labor income in Russia also plays an important role. Generally speaking, previous work on inequality dynamics in transition economies has shown the key role played by labor market forces and wage inequality (see e.g. Flemming and Micklewright, 2000; Yemstov, 2008; Milanovic and Ersado, 2010; EBRD, 2016). Unfortunately the data that we use in the present paper does not allow us to properly disentangle these different factors. Access to more detailed income tax data (with breakdowns by income categories) would be necessary in order to evaluate the respective role of capital income, self-employment income and wage income in the rise of inequality in Russia as compared to other countries.

Finally, we present our findings for wealth inequality. According to our benchmark series, wealth concentration has increased substantially in Russia over the 19952015 period, and now stood at a substantially higher level than in countries like China or France, and a level that is comparable or even higher than the United States (see Figures 12a-12c). 
We should stress, however, that these wealth inequality estimates are even more fragile than our income inequality series. The data sources available to study wealth in Russia are unfortunately much more limited than to study income (where we could rely on combination of household income survey data and income tax data). There exists no reliable household wealth survey, and there exists no wealth tax data and no inheritance tax data (indeed such taxes do not even exist in Russia). In contrast to France and the US (where we have detailed income tax micro files with capital income flows that can be capitalized, and where we also have access to inheritance tax data and household wealth surveys), and in contrast also to China (where at least we have household wealth surveys), all what we have to study wealth inequality in Russia is the Forbes billionaire data. This is a bit better than nothing at all, and this certainly captures something real, but this is not much.

We do our best to combine Forbes billionaire data with normalized wealth distribution data for other countries and generalized Pareto interpolation techniques in order to produce transparent estimates, but we stress that different variants (based upon alternative assumptions regarding how to use the Forbes data) lead to significant margins of error. We can reasonably certain that wealth inequality is very high in Russia by international standards, but it is not possible to be certain for instance as to whether top wealth shares in Russia are higher or not than in the US. They are certainly higher at the level of the top 100 individuals, but we would need more information about individuals who own (say) between ten and one hundred millions dollars (rather than on billionaires only) in order to be able to conclusive regarding the top $1 \%$ or top $0,1 \%$ wealth share (let alone the top $10 \%$ share). ${ }^{39}$

\section{Section 5. Concluding comments and perspectives}

In this paper, we have attempted to combine the various existing data sources in a systematic manner in order to provide consistent series on the accumulation and distribution of income and wealth in Russia from the Soviet period until the present

\footnotetext{
${ }^{39}$ See Appendix B, Figures B51-B57 for alternative series on wealth inequality in Russia. What is reinsuring is that this has a negligible impact of our corrected inequality series, because most of the correction comes from the income tax data rather than from the wealth data. See Figures B30-31.
} 
day. In particular, we have combined national accounts, survey, wealth and fiscal data, including recently released tax data on high-income taxpayers (which to our knowledge was never used before). We have found that official inequality estimates vastly underestimate the concentration of income in Russia. We have also provided the first complete balance sheet series for private wealth, public wealth and national wealth in post-Soviet Russia, including an estimate of offshore wealth.

We should stress again that the lack of data access and financial transparency makes it very difficult to properly analyze inequality dynamics in Russia. In particular, currently available income tax tabulations suffer from major shortcomings and ought to be extended and improved. ${ }^{40}$ We have done our best to combine the various existing data sources in the most plausible manner, but the quality of raw available data remains highly insufficient.

Our findings on long run distributional trends in Russia also confirm the importance of policies, institutions and ideology for understanding inequality dynamics. The dramatic failure of Soviet communism and egalitarian ideology - in the form it was applied in Russia - seems to have led to relatively high tolerance for large inequality and concentration of private property (partly coming from outright plundering of the country's natural resources and foreign reserves). In effect, extreme inequality seems acceptable in Russia, as long as billionaires and oligarchs appear to be loyal to the Russian state and perceived national interests. Whether this fragile equilibrium will persist in the coming years and decades remains to be seen.

\section{References}

F. Alvaredo, T. Atkinson, L. Chancel, T. Piketty, E. Saez, G. Zucman, "Distributional National Accounts (DINA) Guidelines: Concepts and Methods used in WID.world", WID.world Working Paper 2016/02

\footnotetext{
${ }^{40}$ See section 2.2 above and Appendix B.
} 
A.B. Atkinson, J. Micklewright, Economic transformation in Eastern Europe and the distribution of income, Cambridge University Press, 1992

E. Berglöf, G. Roland, "The EU as an Outside Anchor for Transition Reforms”, SITE Working Paper 132, 1997

T. Blanchet, J. Fournier, T. Piketty, "Generalized Pareto Curves: Theory and Applications ", WID.world Working Paper 2017/03

E. Brainerd, D. M. Cutler. "Autopsy on an Empire: Understanding Mortality in Russia and the Former Soviet Union" Journal of Economic Perspectives, 2005, 19(1), p. 107130

A. Bergson, "Distribution of the Earnings Bill Among Industrial Workers in the Soviet Union”, Journal of Political Economy, 1942, 50(2), p.227-249

A. Bergson, The Structure of Soviet Wages - A Study in Socialist Economics, Harvard University Press, 1944

A. Bergson, "Income Inequality Under Soviet Socialism", Journal of Economic Literature, 1984, vol.22, p.1052-1099

M. Boycko, A. Shleifer, R. Vishny, Privatizing Russia, MIT Press, 1995

J. Davies, S. Sandstrom, A. Shorrocks, E. Wolff, "The Level and Distribution of Global Household Wealth", The Economic Journal, 2011

J. Davies, R. Lluberas, A. Shorrocks, Global Wealth Report and Databook, Credit Suisse Research Institute, 2010-2016, annual publication

T. Dennison, "The Institutional Framework of Serfdom in Russia: the View from 1861", in S. Cavaciocchi ed., Serfdom and Slavery in the European Economy, 11 ${ }^{\text {th }}$ $18^{\text {th }}$ centuries, p.83-96, Firenze University Press, 2014 
European Bank for Reconstruction and Development (EBRD), Transition for All: Equal Opportunities in an Unequal World, Transition Report 2016-2017 (October 2016)

J. Flemming, J. Micklewright, "Income Distribution, Economic Systems and Transition", in A.B. Atkinson and F. Bourguignon, eds., Handbook of Income Distribution, chap.14, p.843-918, North-Holland, 2000

C. Gaddy, B. Ickes, Russia's virtual economy, Washington: Brookings Institution Press, 2002

B. Garbinti, J. Goupille, T. Piketty, "Income Inequality in France, 1900-2014: Evidence from Distributional National Accounts (DINA)", WID.world Working Paper $2017 / 04$

B. Garbinti, J. Goupille-Lebret, T. Piketty, "Accounting for Wealth Inequality Dynamics: Methods, Estimates and Simulations for France (1800-2014)", WID.world Working Paper 2016/05

R. Goldsmith, "The National Balance Sheet of the USSR", in C. Rao ed., Essays in Econometrics and Planning, p.83-102, Pergamon Press, 1965

Gregory, P., Russian National Income, 1885-1913, CUP, 1982

S. Guriev, A. Rachinsky, "The Role of Oligarchs in Russian Capitalism", Journal of Economic Perspectives, 2005, 19(1), p.131-150

S. Guriev, A. Rachinsky, "The Evolution of Personal Wealth in the Former Soviet Union and Central and Eastern Europe", UNU/WIDER 2006/120

T. Gustafson, Wheel of Fortune: The Battle for Oil and Power in Russia, Harvard University Press, 2012 
N. Kosareva, R. Stryuk, A. Tkachenko, "Russia: Dramatic Shift to Demand-Side Assistance", In R. Stryuk ed., Homeownership and housing finance policy in the former Soviet bloc: Costly populism, p.151-215, The Urban Institute, 2000

P. Kozyreva, M. Kosolapov, B.M. Popkin, "Data Resource Profile: The Russia Longitudinal Monitoring Survey-Higher School of Economics (RLMS-HSE) Phase II: Monitoring the Economic and Health Situation in Russia, 1994-2013", International Journal of Epidemiology 2015, p.1-7

P. Lindert, S. Nafziger, "Russian Inequality on the Eve of the Revolution", NBER Working Paper, 2012

A. Maddison, "Measuring the Performance of a Command Economy: An Assessment of the CIA Estimates for the USSR", Review of Income and Wealth, 1998

Maddison Project. Available at http://www.ggdc.net/maddison/maddisonproject/home.htm, 2013

M. Matthews, Privilege in the Soviet Union. London: Allen \& Unwin, 1978

D. Mavridis, P. Mosberger, "Income inequality and incentives: The quasi-natural experiment of Hungary, 1914-2008”, WID.world Working Paper 2017/17

B. Milanovic, L. Ersado, "Reform and inequality during the transition: An analysis using panel houshold survey data, 1990-2005", UNU-WIDER, 2010/62

D. Nougayrede, "Outsourcing Law in Post-Soviet Russia", Journal of Eurasian Law, 2014, p.383-448

D. Nougayrede, "Yukos, Investment Round-Tripping and the Evolving Public-Private Paradigm", American Review of International Arbitration, 2015, 26(3), p.337-364

D. Nougayrede, "The Use of Offshore Companies in Emerging Market Economies: a Case Study", Columbia Journal of European Law, 2017, 23(2), 401-440 
F. Novokmet, "Between Communism and Capitalism: on the evolution of income and wealth inequality in Eastern Europe 1890-2015 (Czech Republic, Poland, Bulgaria, Croatia, Slovenia and Russia)", PhD Dissertation, PSE, 2017

T. Piketty, Les hauts revenus en France au $20^{e}$ siècle, Grasset 2001

T. Piketty, Capital in the $21^{\text {st }}$ century, Harvard University Press, 2014

T. Piketty, E. Saez, G. Zucman, "Distributional National Accounts: Methods and Estimates for the U.S.", WID.world Working Paper, 2016

T. Piketty, L. Yang, G. Zucman, "Capital Accumulation, Private Property and Rising Inequality in China, 1978-2015", WID.world Working Paper 2017/06

T. Piketty, G. Zucman (2014). Capital is Back: Wealth-Income Ratios in Rich Countries 1700-2010. The Quarterly Journal of Economics, 129(3), 1255-1310.

A. N. Ponomarenko, Retrospektivye national'nye scheta Rossii: 1961-1990, Moscow: Finansy i statistika, 2002

G. Roland. "The evolution of post-communist systems: Eastern Europe versus China", mimeo, 2017

E. Saez, G. Zucman (2016). Wealth Inequality in the United States: Evidence from Capitalized Income Tax Data. The Quarterly Journal of Economics, 131(2), 519-578.

E. Todd, La chute finale. Essai sur la decomposition de la sphère soviétique, R. Laffont, 1976 (The Final Fall. An essay on the decomposition of the Soviet sphere, Karz Publishers, 1979)

D. Treisman, "Russia's Billionaires”, American Economic Review, 2016, p.236-241 
R. Yemtsov, "Through the Looking-Glass: What is behind official data on inequality in Russia over 1992-2003?", World Bank, Working Paper, 2008

G. Zucman, "The Missing Wealth of Nations, Are Europe and the U.S. net Debtors or net Creditors?", Quarterly Journal of Economics, 2013, 128(3), p.1321-1364

G. Zucman, "Taxing Across Borders: Tracking Personal Wealth and Corporate Profits", Journal of Economic Perspectives, 2014, 28(4), p.121-148

G. Zucman, The Hidden Wealth of Nations, University of Chicago Press, 2015 


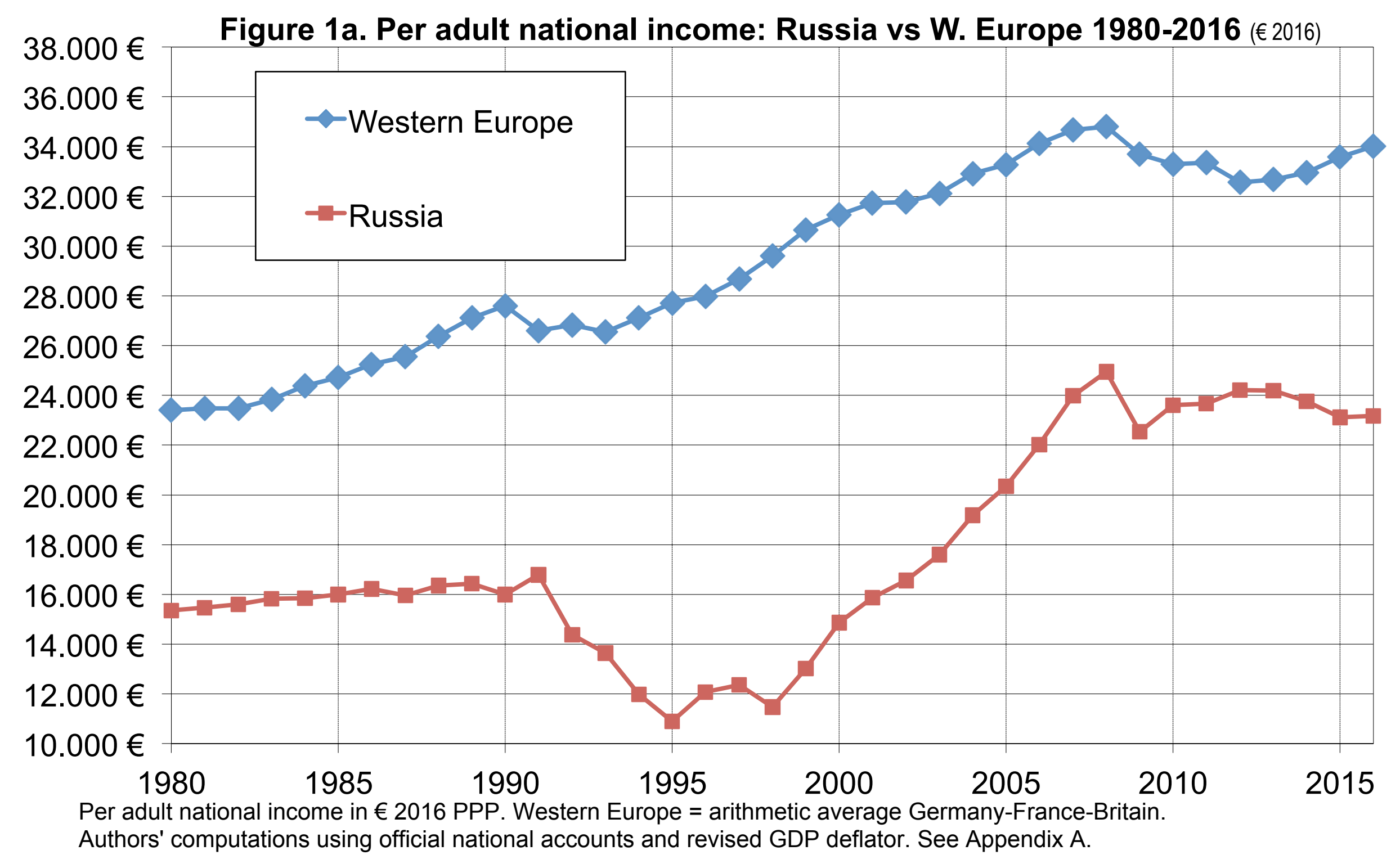


Figure 1b. Per adult national income: ratio Russia/W.Europe, 1870-2016

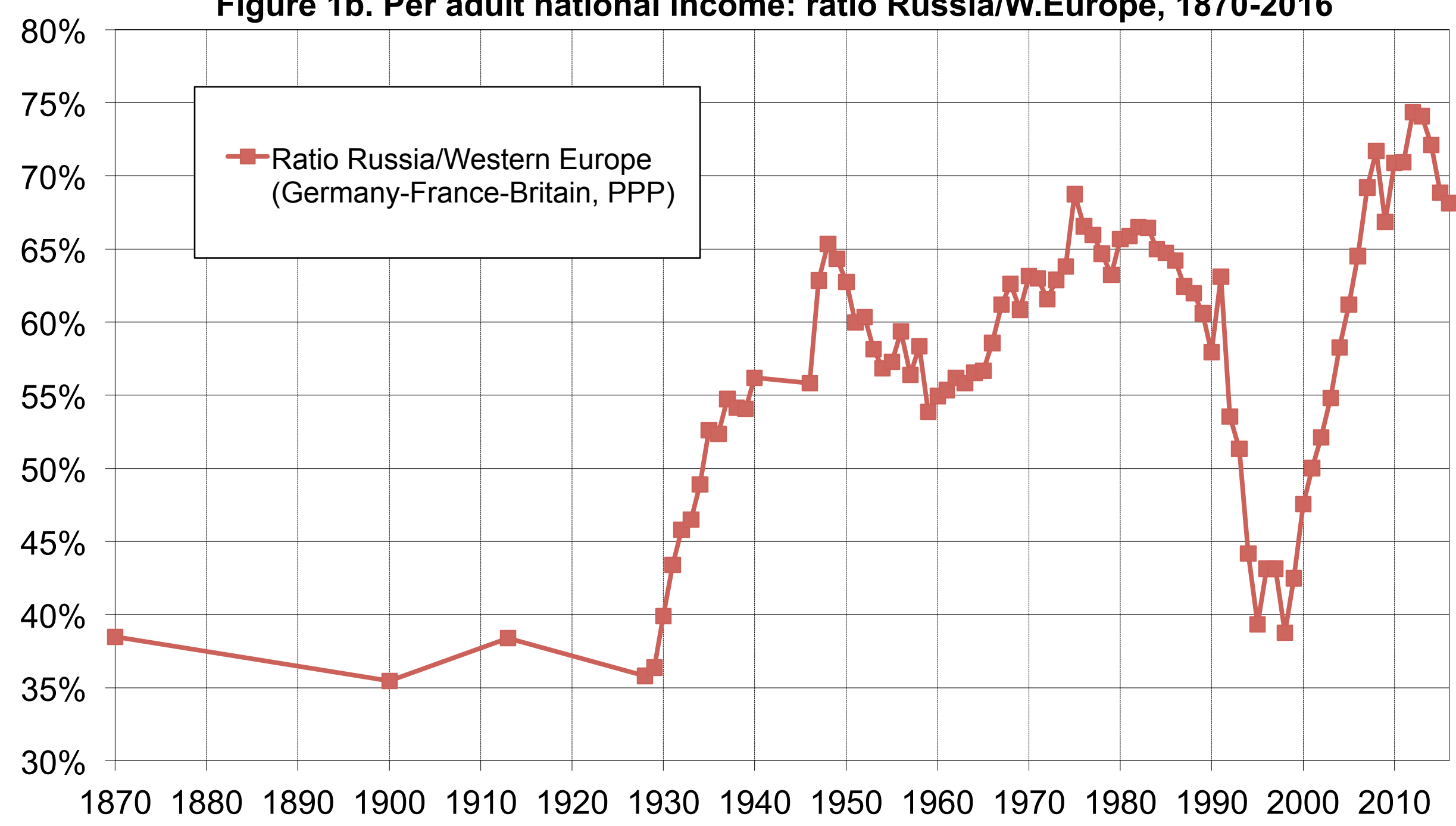

Per adult national income in € 2016 PPP. Western Europe = arithmetic average Germany-France-Britain. 
Figure 2. Total Forbes billionaire wealth (\% national income):

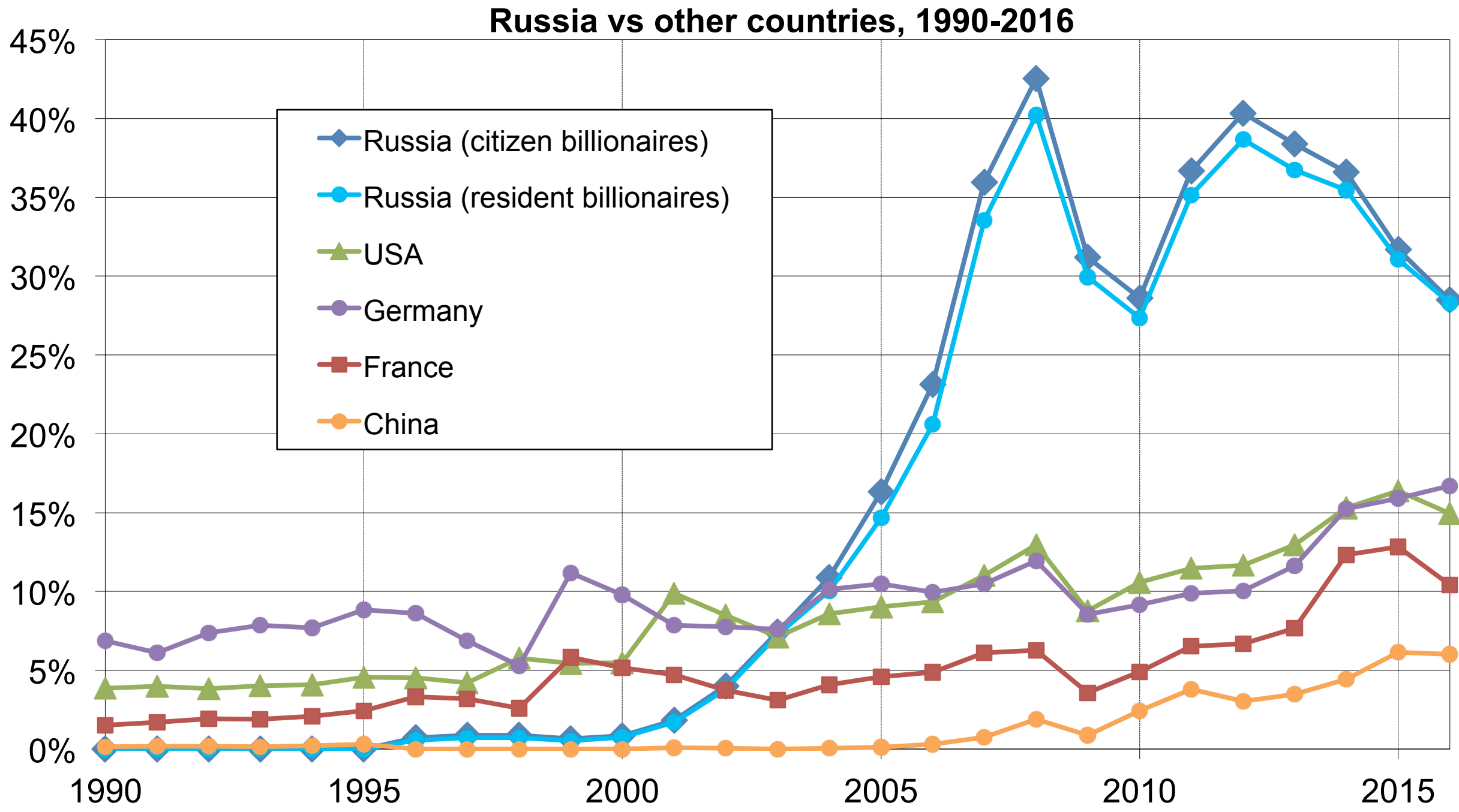

Total billionaire wealth (as recorded by Forbes global list of dollar billionaires) divided by national income (measured at market exchange rates). For other countries, we only report citizen billionaires (numbers for resident billionaires are virtually identical). 
Figure 3: Public vs private property in Russia 1990-2015 (\% national income)

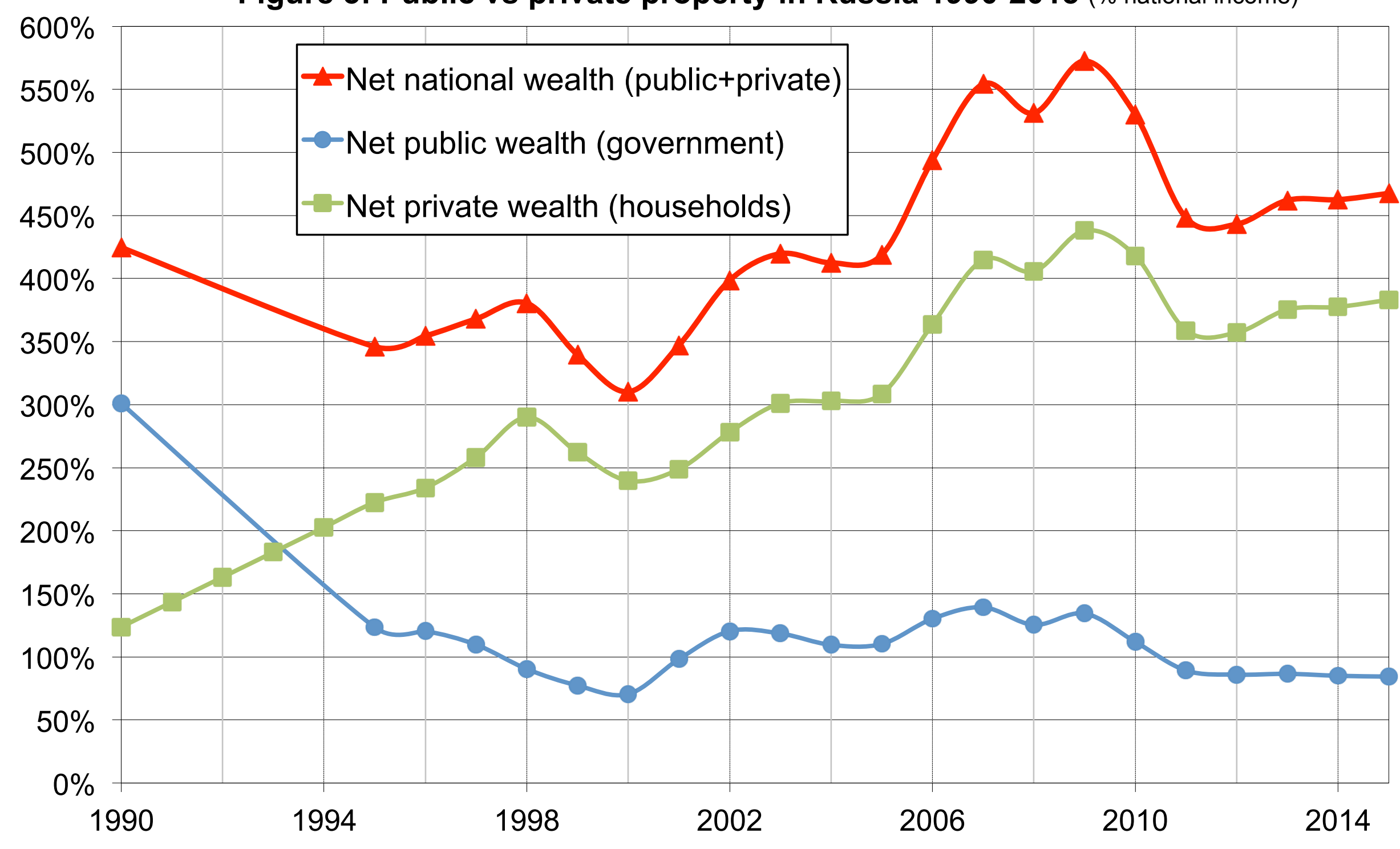




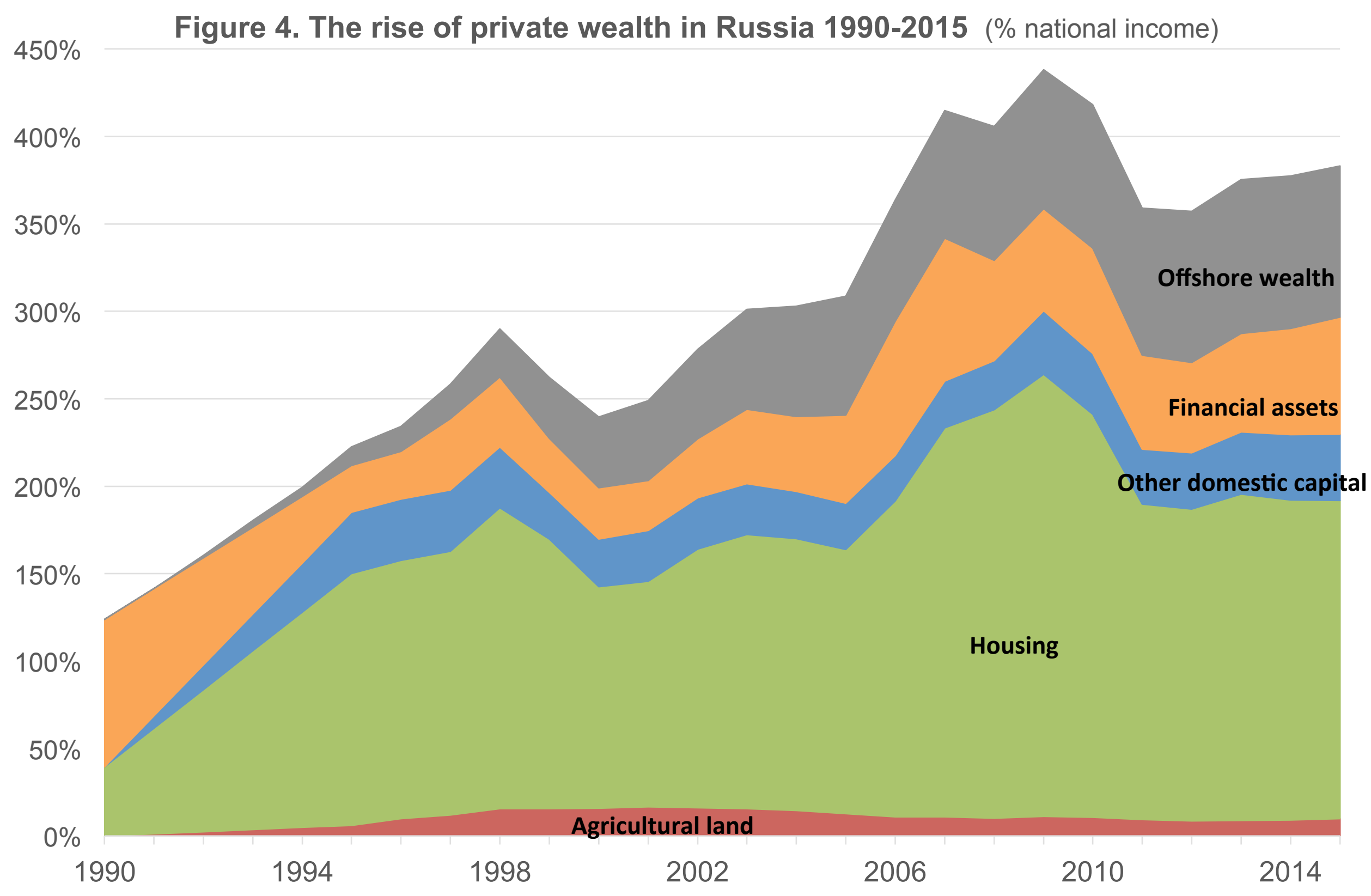


Figure 5a. Trade surplus and missing foreign assets in Russia 1990-2015

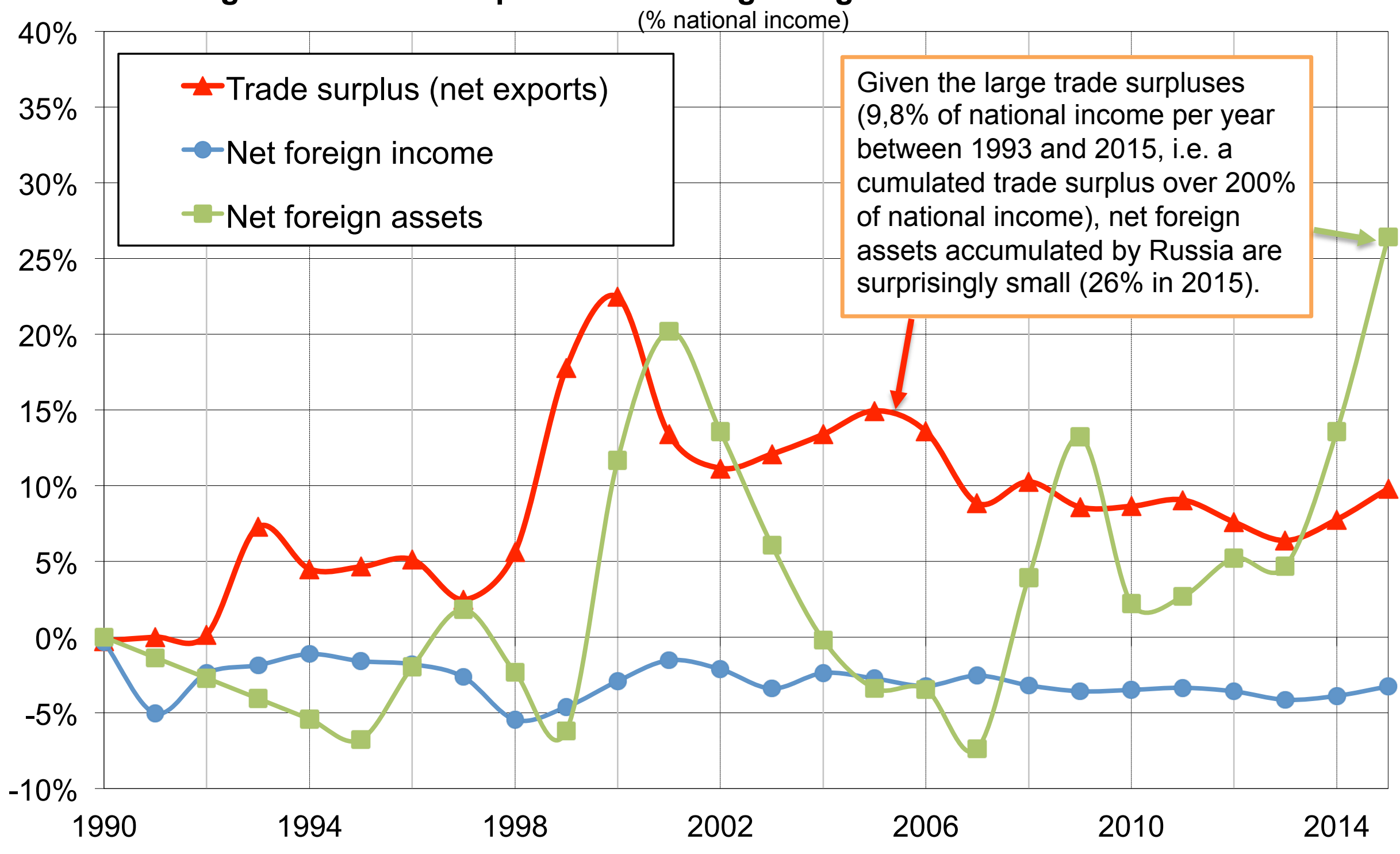


Figure 5b. Russia's official foreign assets and liabilities 1990-2015

(\% national income)

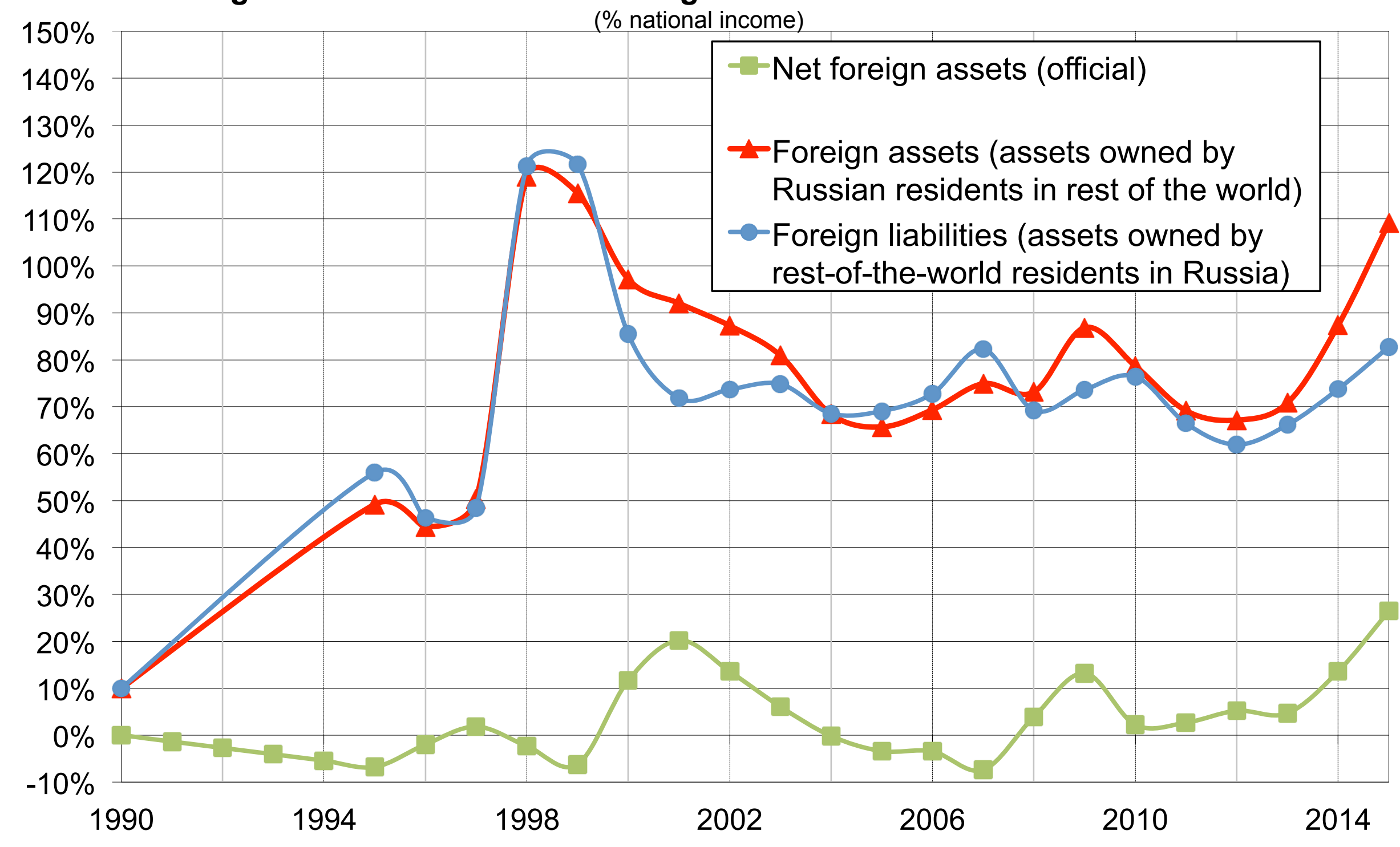


Figure 5c. Estimating Russia's missing foreign assets 1990-2015

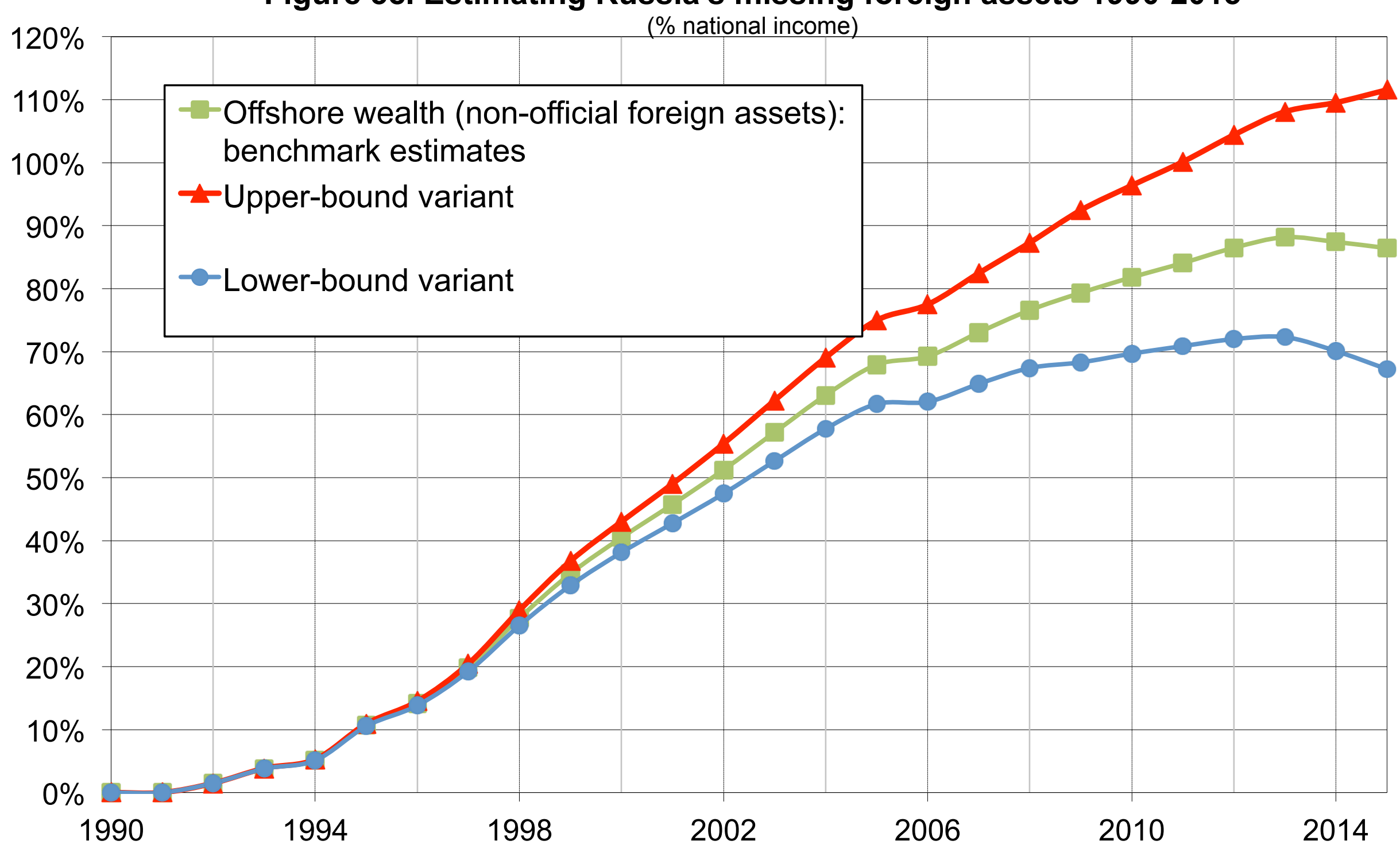


Figure 6a. The structure of national wealth in Russia 1990-2015

$700 \%$

(market-value national wealth, \% national income)

$650 \%$

$600 \%$

$550 \%$

$500 \%$

$450 \%$

$400 \%$

$350 \%$

$300 \%$

$250 \%$

$200 \%$

$150 \%$

$100 \%$

$50 \%$

$0 \%$

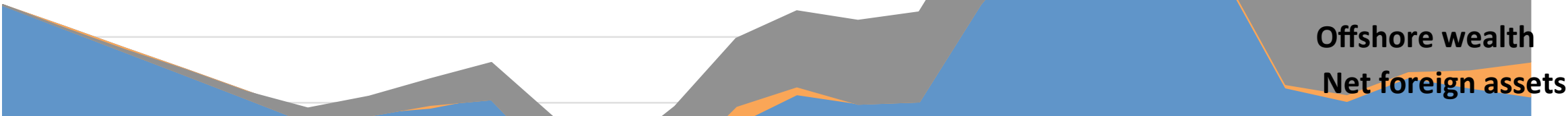

1990

1994

1998

Agricultural land

Other domestic

capital

Housing

Net foreign assets 
Figure 6b. The structure of national wealth in Russia 1990-2015

$700 \%$

(book-value national wealth, \% national income)

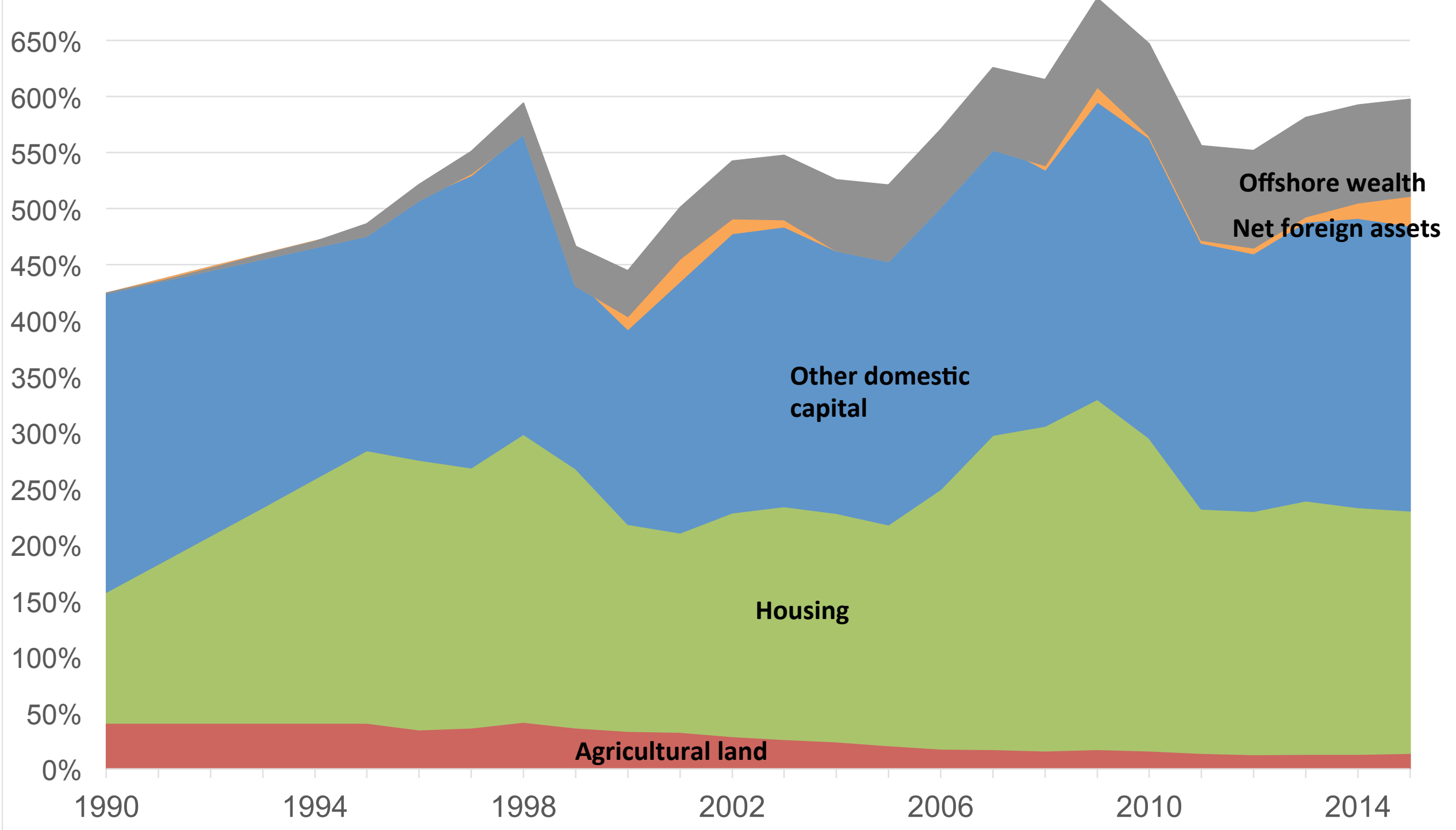


Figure 7a: The rise of private wealth: Russia vs China \& rich countries

(private wealth (households), in \% national income)

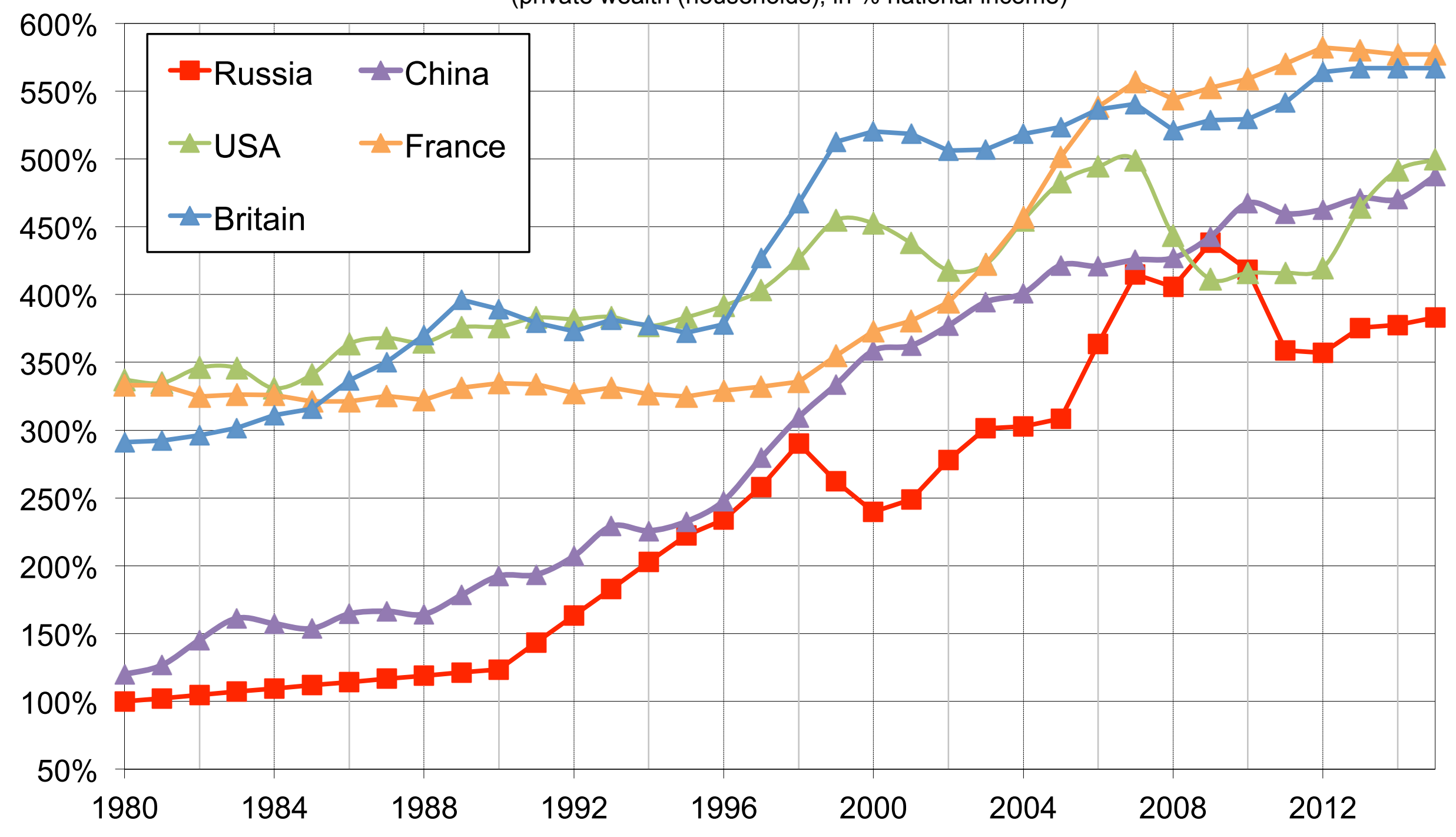


Figure 7b: National wealth accumulation: Russia vs China \& rich countries (national wealth (private+public), in \% national income)

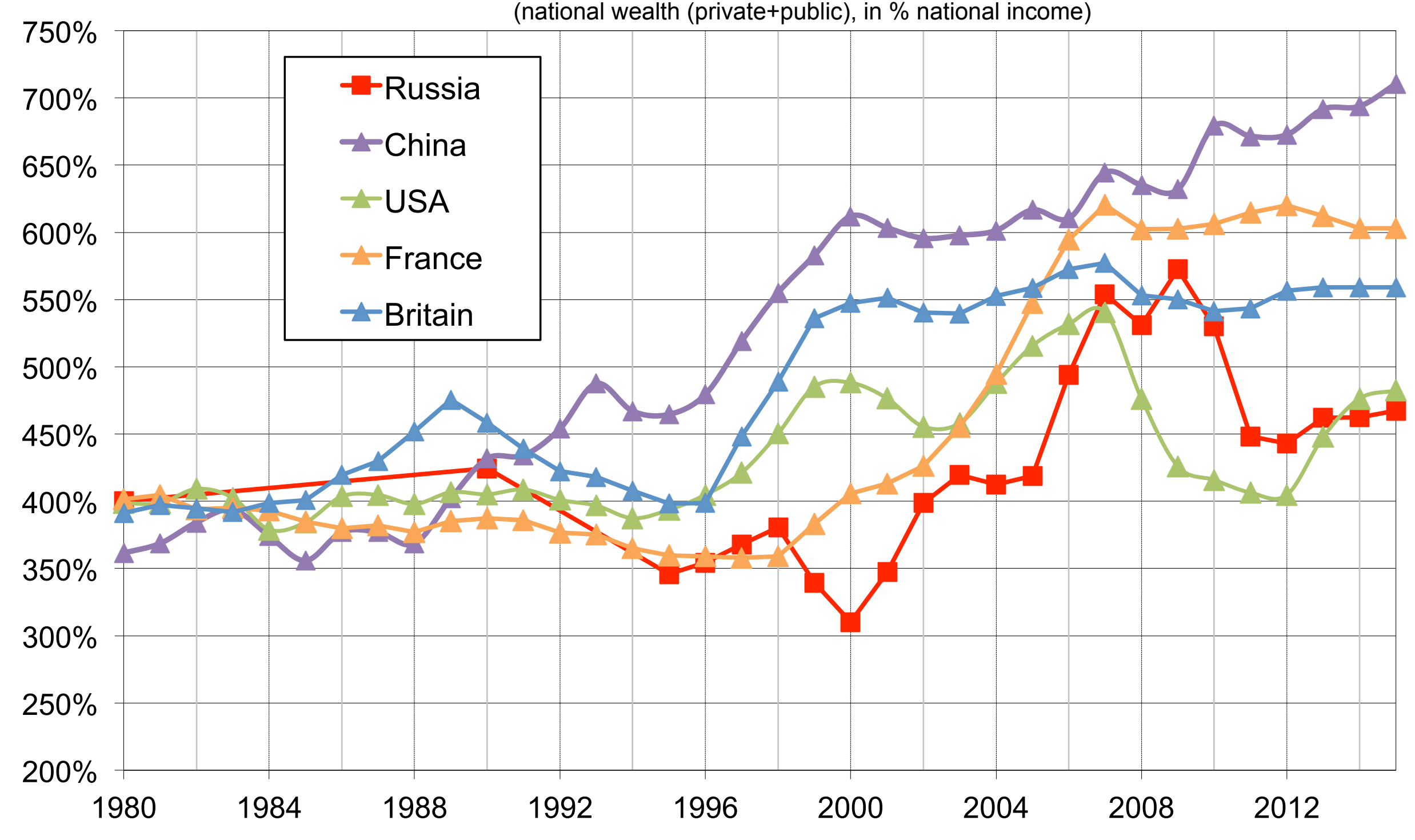


Figure 7c. The decline of public property: Russia vs other countries (share of net public wealth in net national wealth)

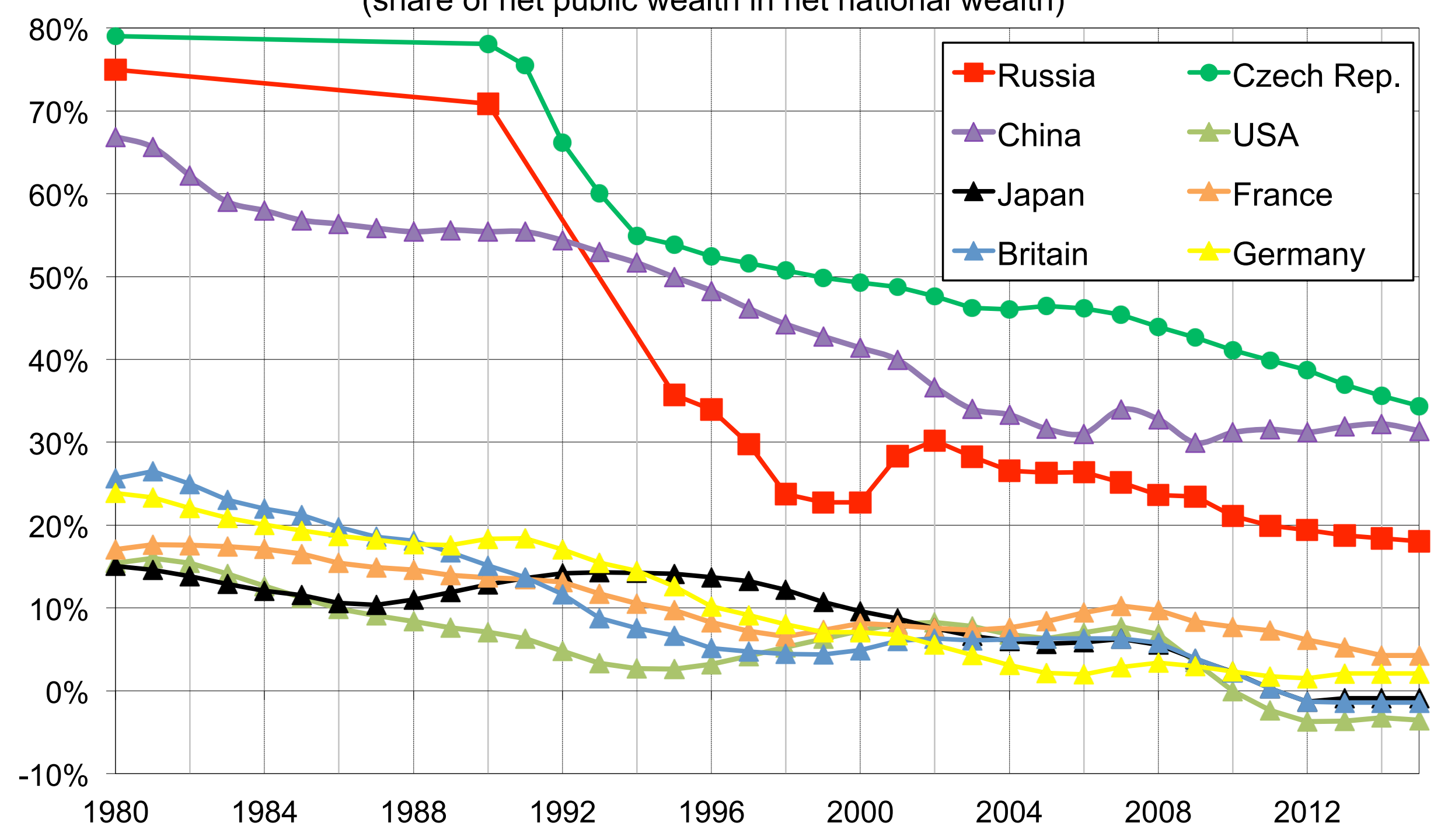


Figure 7d. Net foreign assets: Russia vs other ex-communist countries (1)

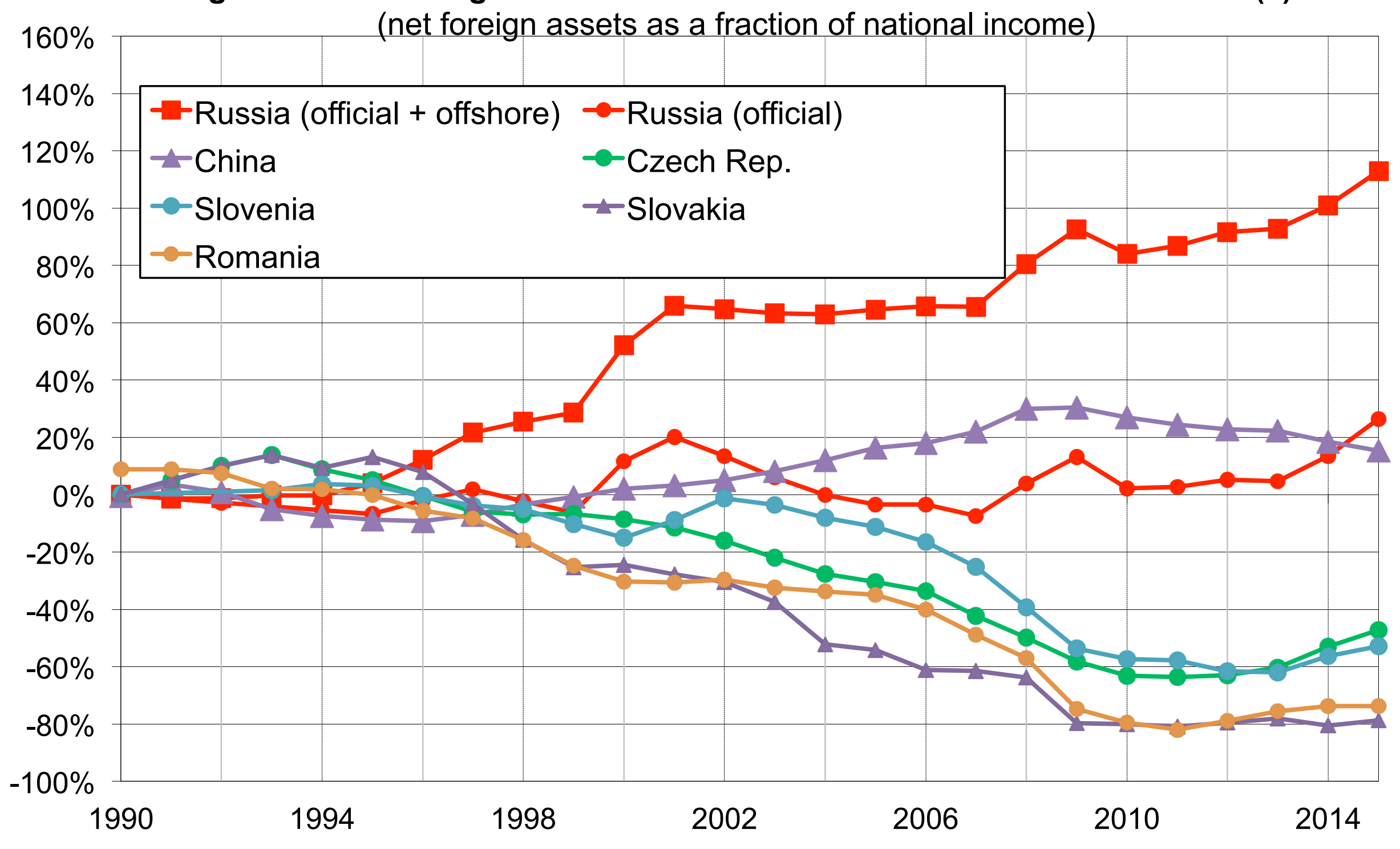


Figure 7e. Net foreign assets: Russia vs other ex-communist countries (2)

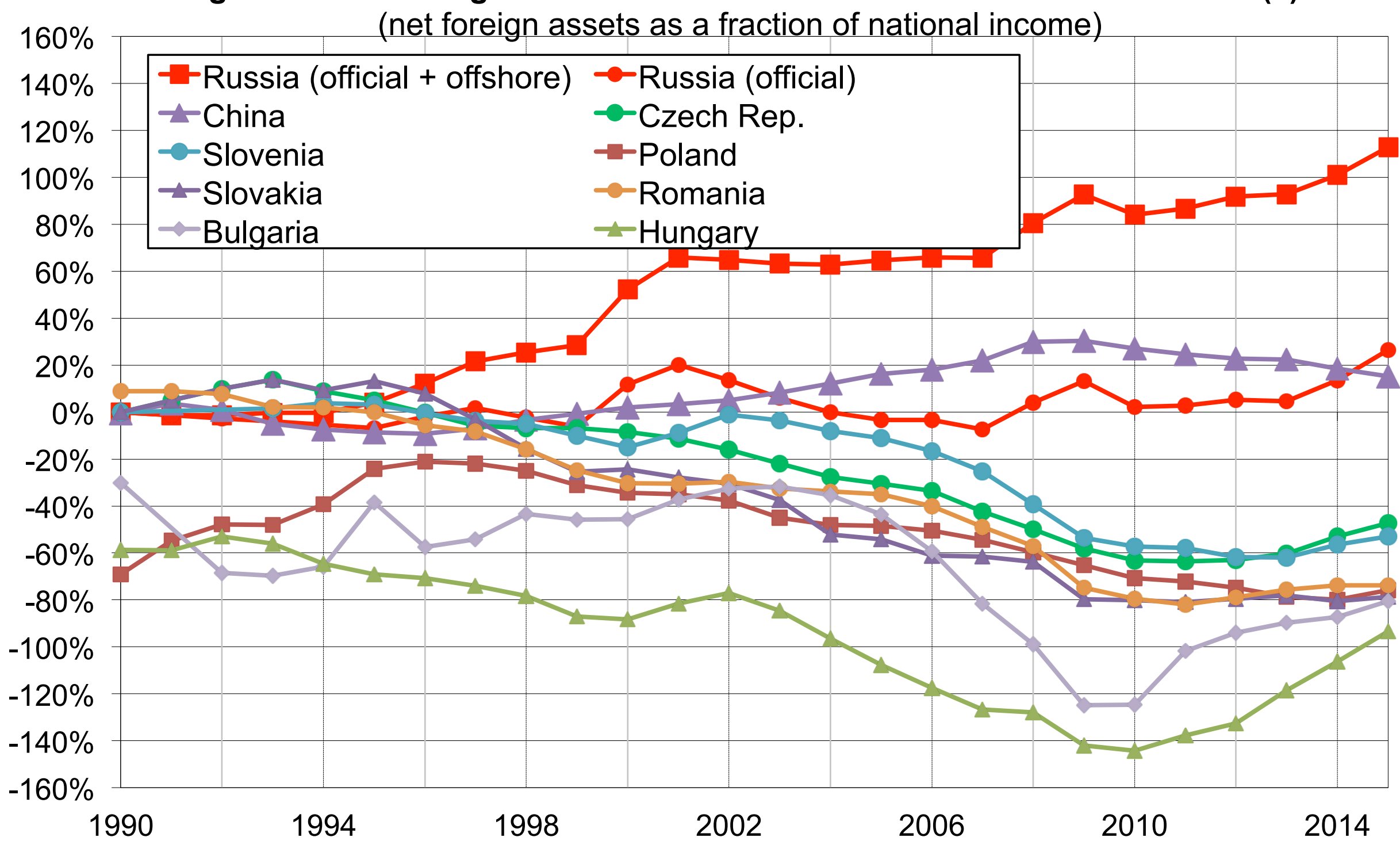


Figure 7f. Net foreign assets: Russia vs other oil-rich countries

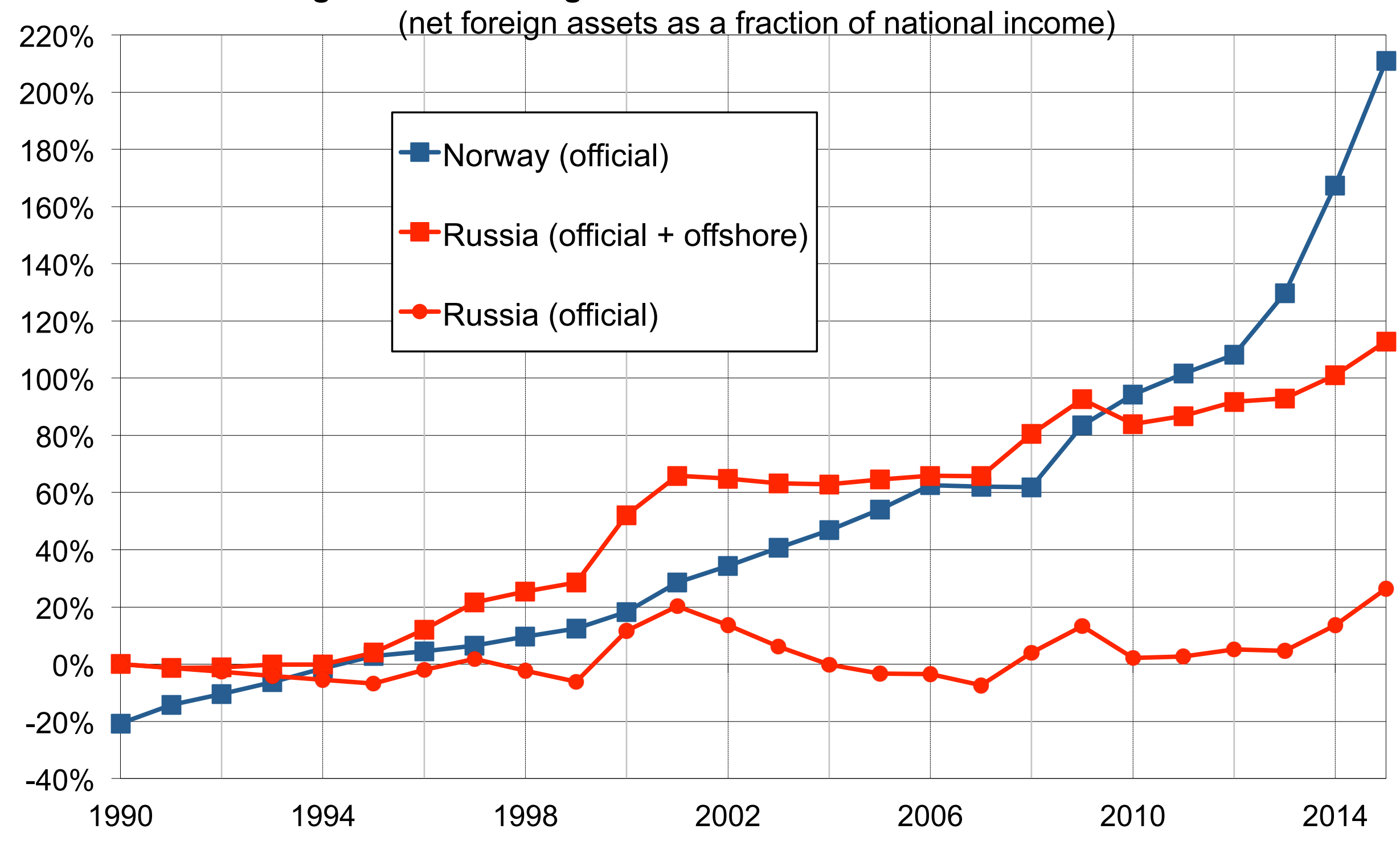




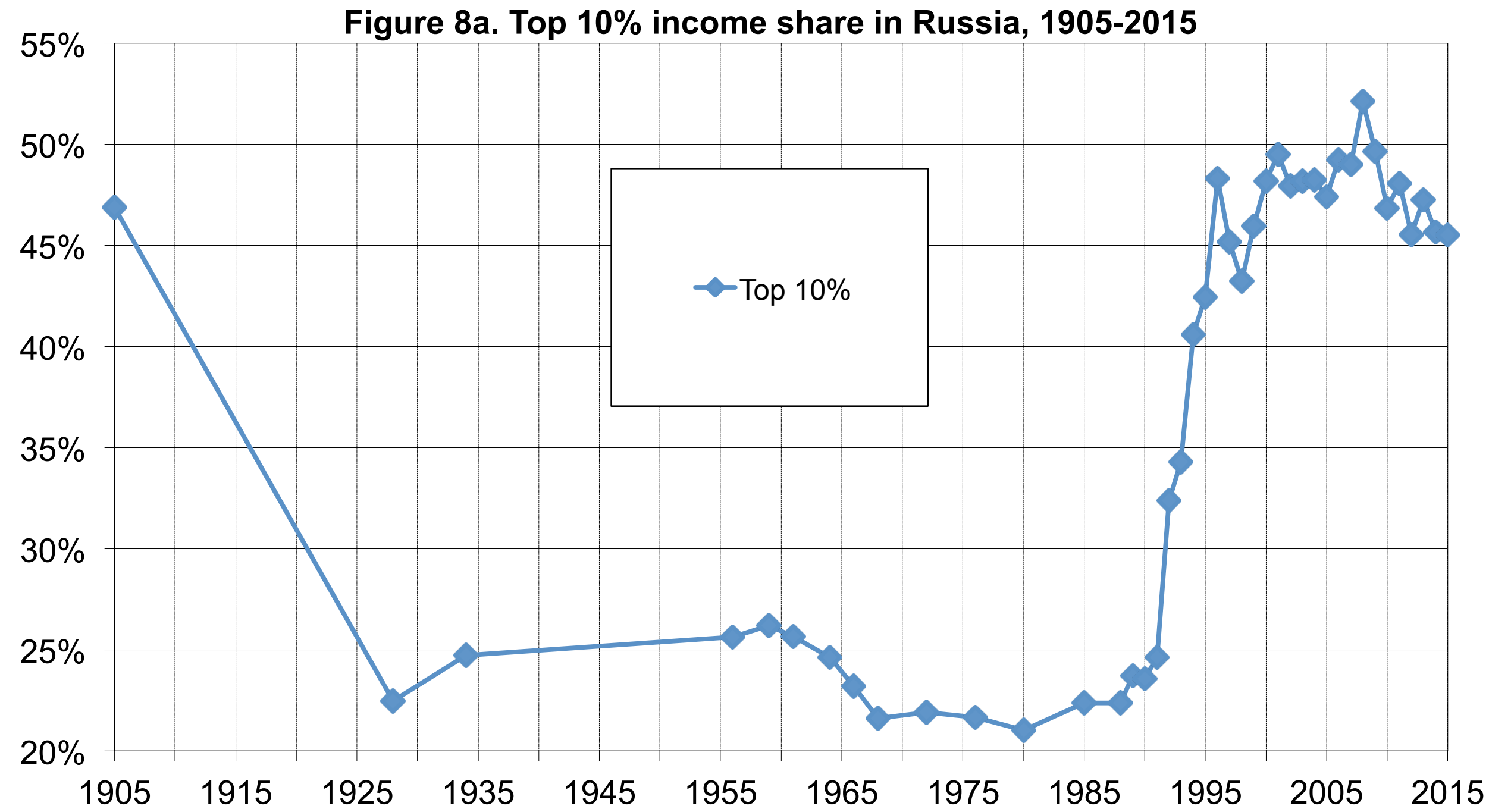

Distribution of pretax national income (before taxes and transfers, except pensions and unempl. insurance) among adults.

Corrected estimates combine survey, fiscal, wealth and national accounts data. Raw estimates rely only on self-reported survey data. Equal-split-adults series (income of married couples divided by two). 
Figure 8b. Top 1\% income share in Russia, 1905-2015

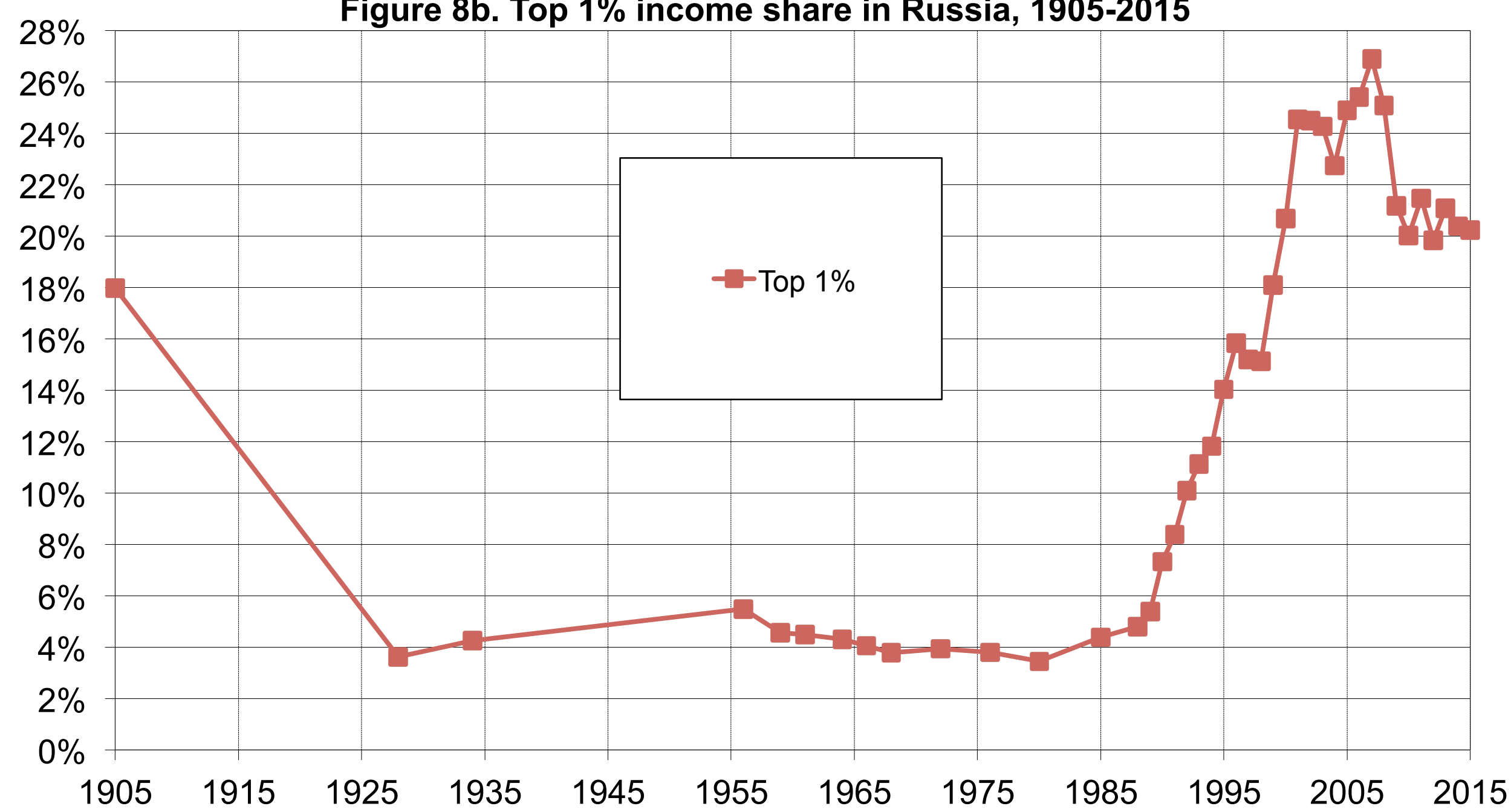

Distribution of pretax national income (before taxes and transfers, except pensions and unempl. insurance) among adults.

Corrected estimates combine survey, fiscal, wealth and national accounts data. Raw estimates rely only on self-reported survey data. Equal-split-adults series (income of married couples divided by two). 


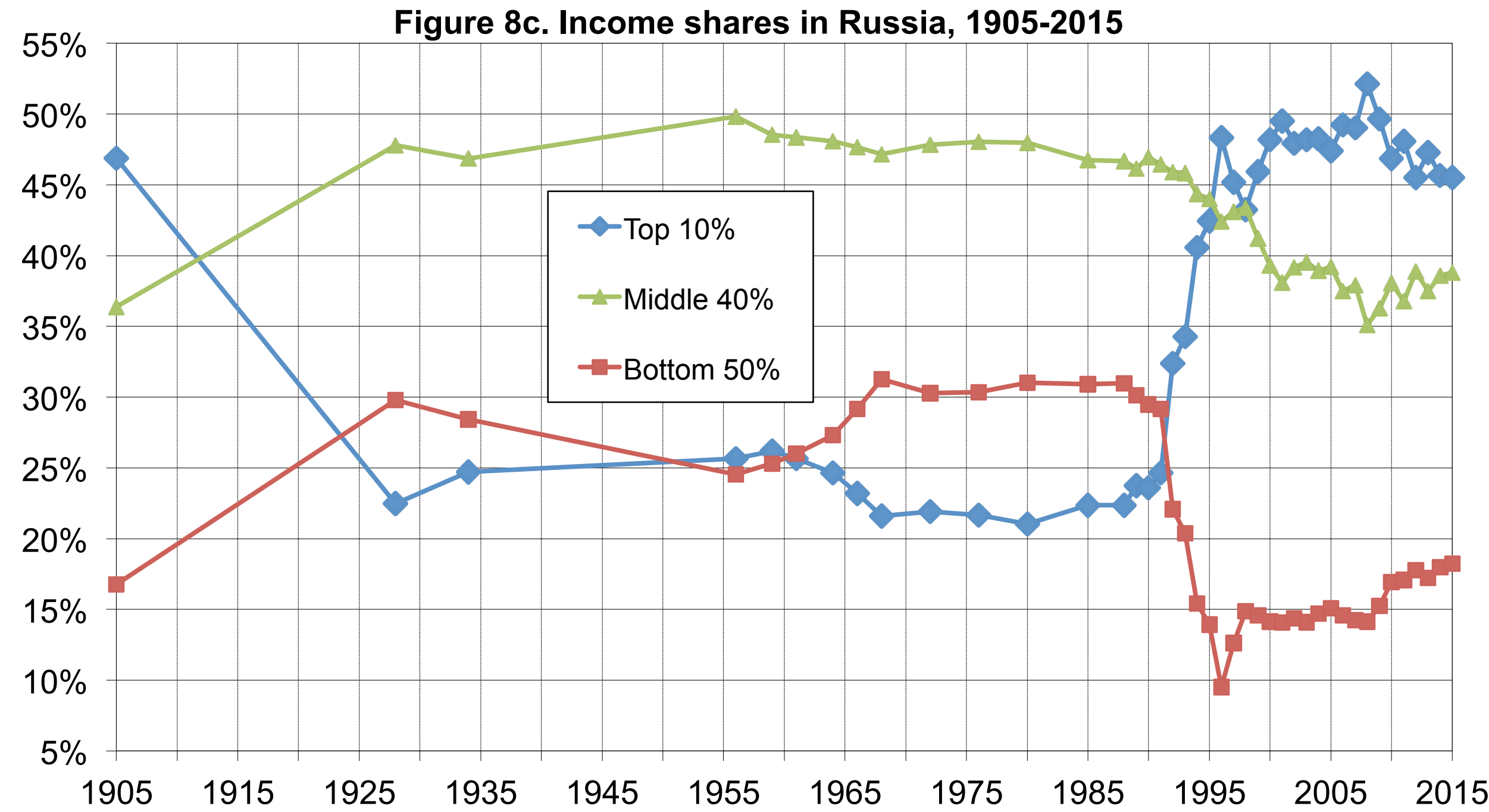

Distribution of pretax national income (before taxes and transfers, except pensions and unempl. insurance) among adults.

Corrected estimates combine survey, fiscal, wealth and national accounts data. Raw estimates rely only on self-reported survey data. Equal-split-adults series (income of married couples divided by two). 
Figure 9a. Cumulative real growth by percentile, Russia 1989-2016

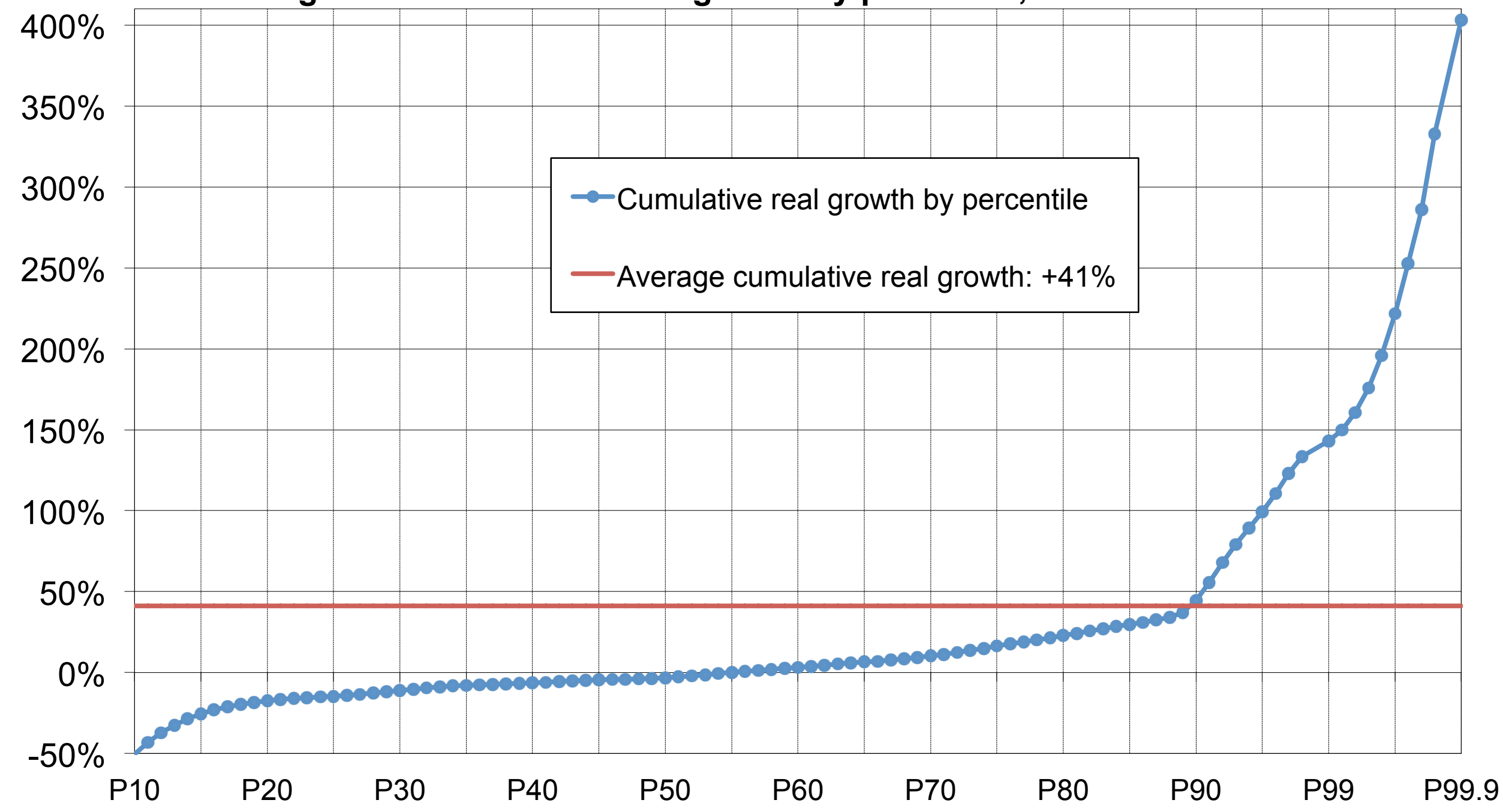

Distribution of pretax national income (before taxes and transfers, except pensions and unempl. insurance) among equal-split adults (income of married couples divided by two). Corrected estimates combine survey, fiscal, wealth and national accounts data. 
Figure 9b. Annual real growth rates by percentile, Russia 1905-2016

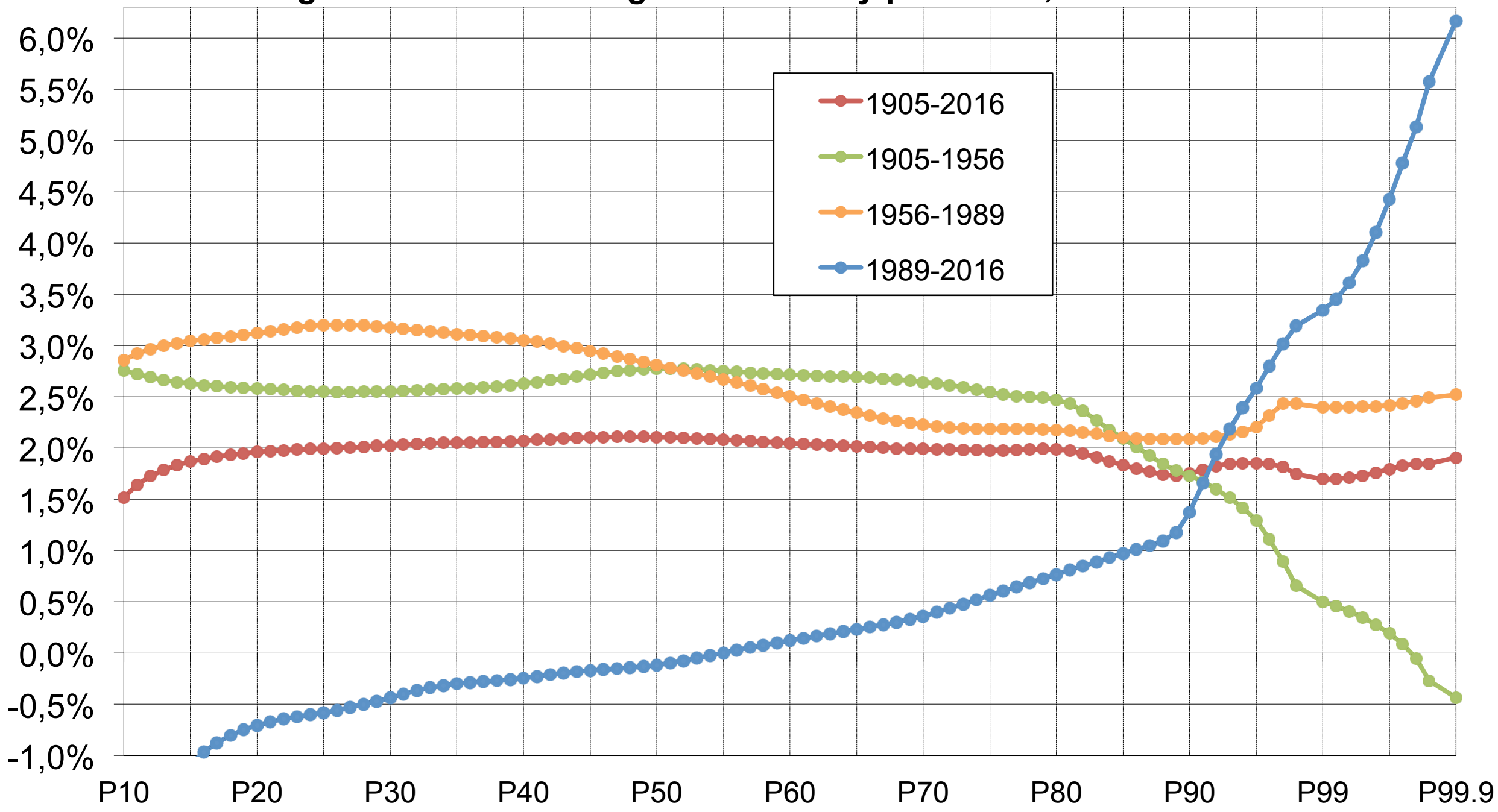

Distribution of pretax national income (before taxes and transfers, except pensions and unempl. insurance) among equal-split adults (income of married couples divided by two). Corrected estimates combine survey, fiscal, wealth and national accounts data. 
Figure 10a. Top 10\% income share in Russia, 1980-2015

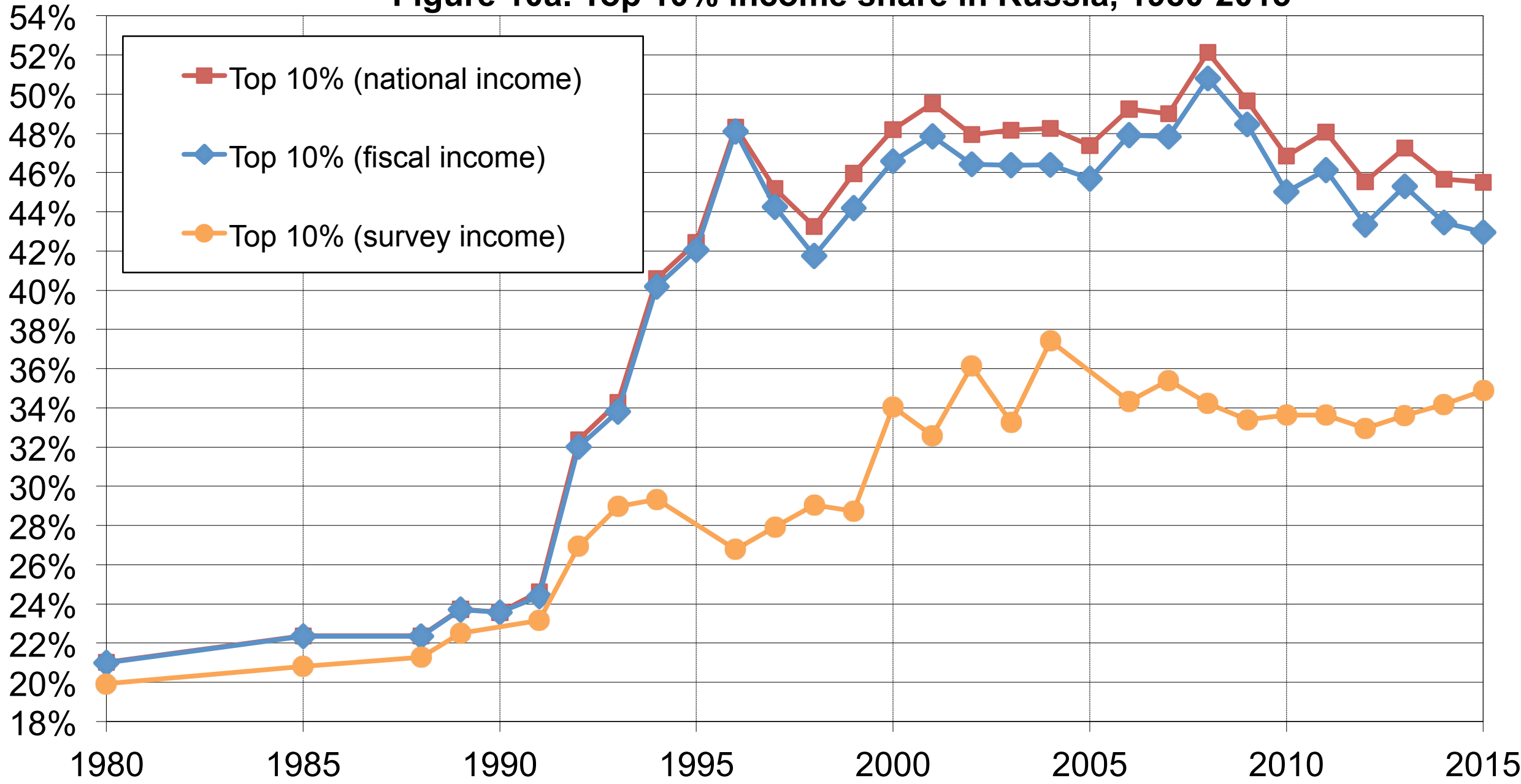

Distribution of income (before taxes and transfers, except pensions and unempl. insurance) among equals-plit adults (income of married couples divided by two). Pretax national income estimates combine survey, fiscal, wealth and national accounts data. Fiscal income estimates combine survey and income tax data (but do not use wealth data to allocate tax-exempt capital income). Survey income series solely use self-reported survey data (HBS). 
Figure 10b. Top 1\% income share in Russia, 1980-2015

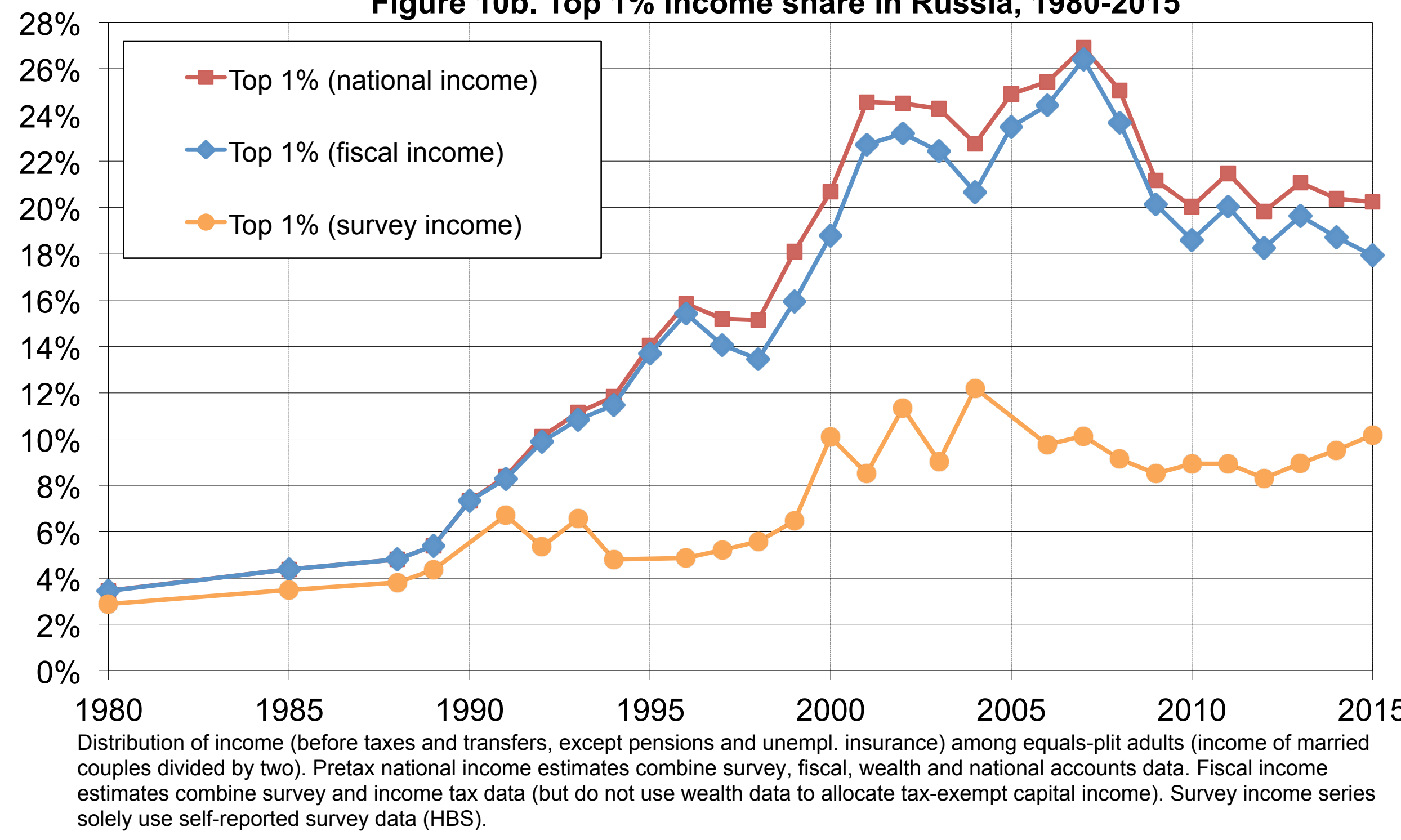


Figure 10c. Gini coefficients in Russia, 1980-2015

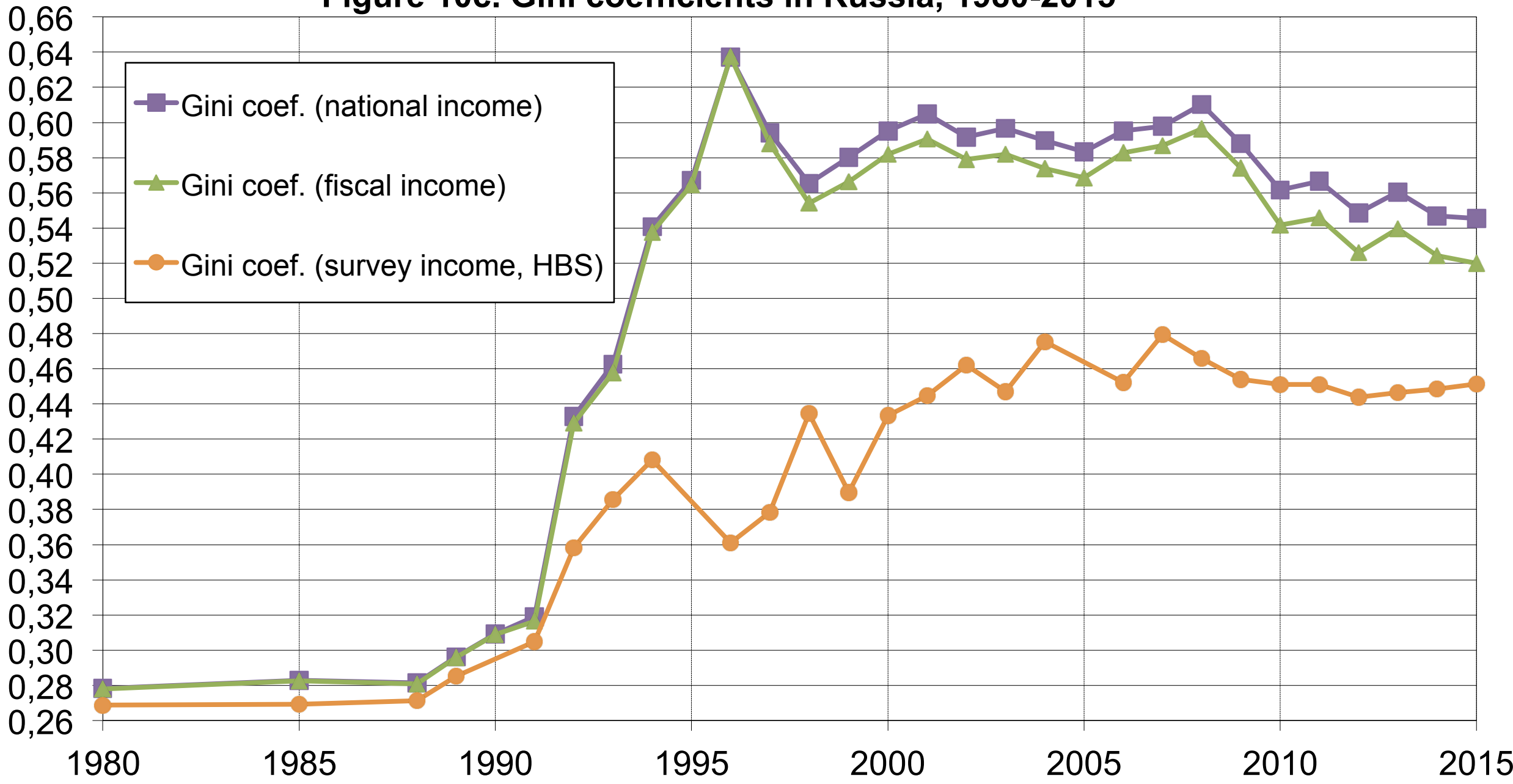

Distribution of income (before taxes and transfers, except pensions and unempl. insurance) among equals-plit adults (income of married couples divided by two). Pretax national income estimates combine survey, fiscal, wealth and national accounts data. Fiscal income estimates combine survey and income tax data (but do not use wealth data to allocate tax-exempt capital income). Survey income series solely use self-reported survey data (HBS). 


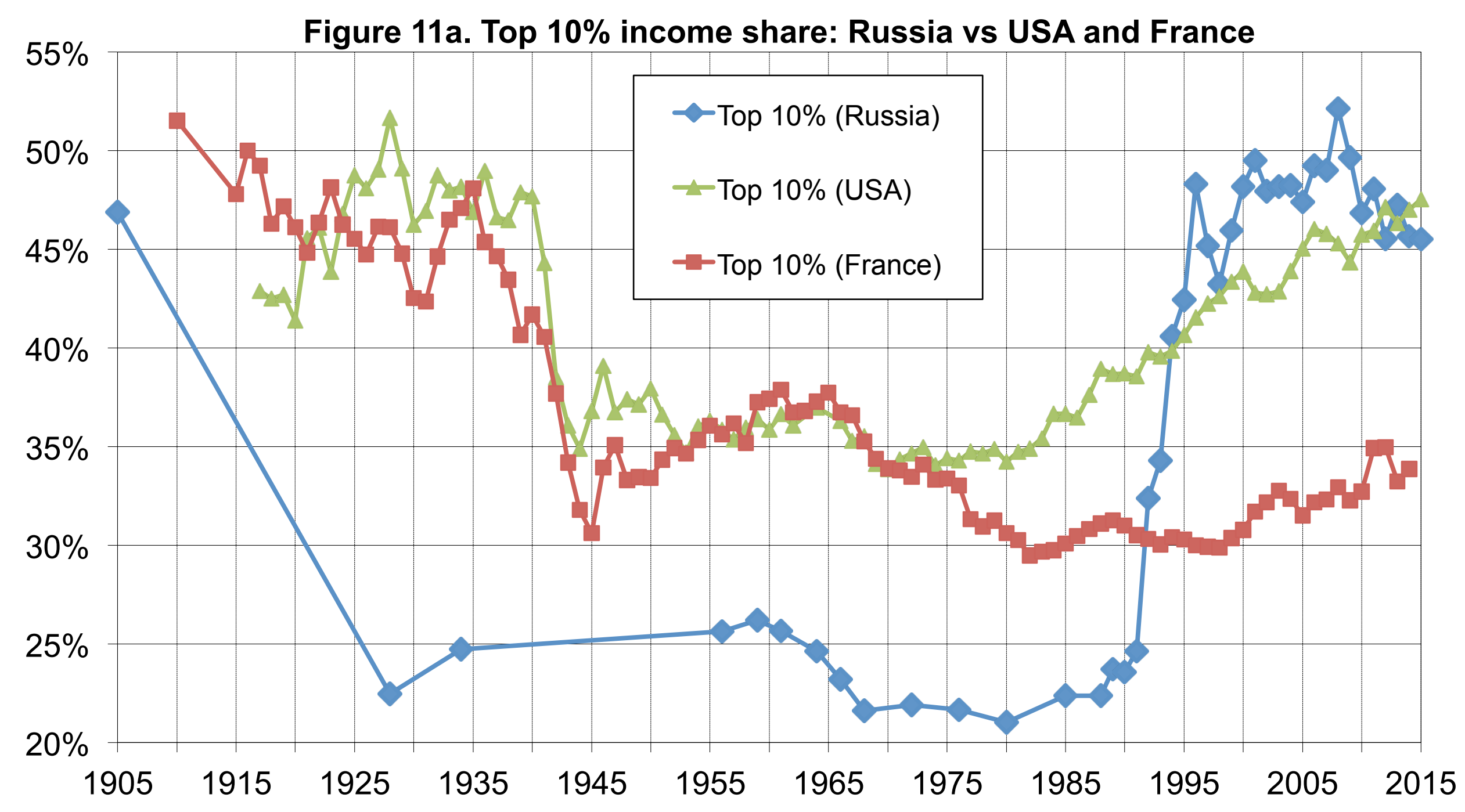

Distribution of pretax national income (before taxes and transfers, except pensions and unempl. insurance) among equal-split adults (income of married couples divided by two). Sources for USA and France: WID.world. 


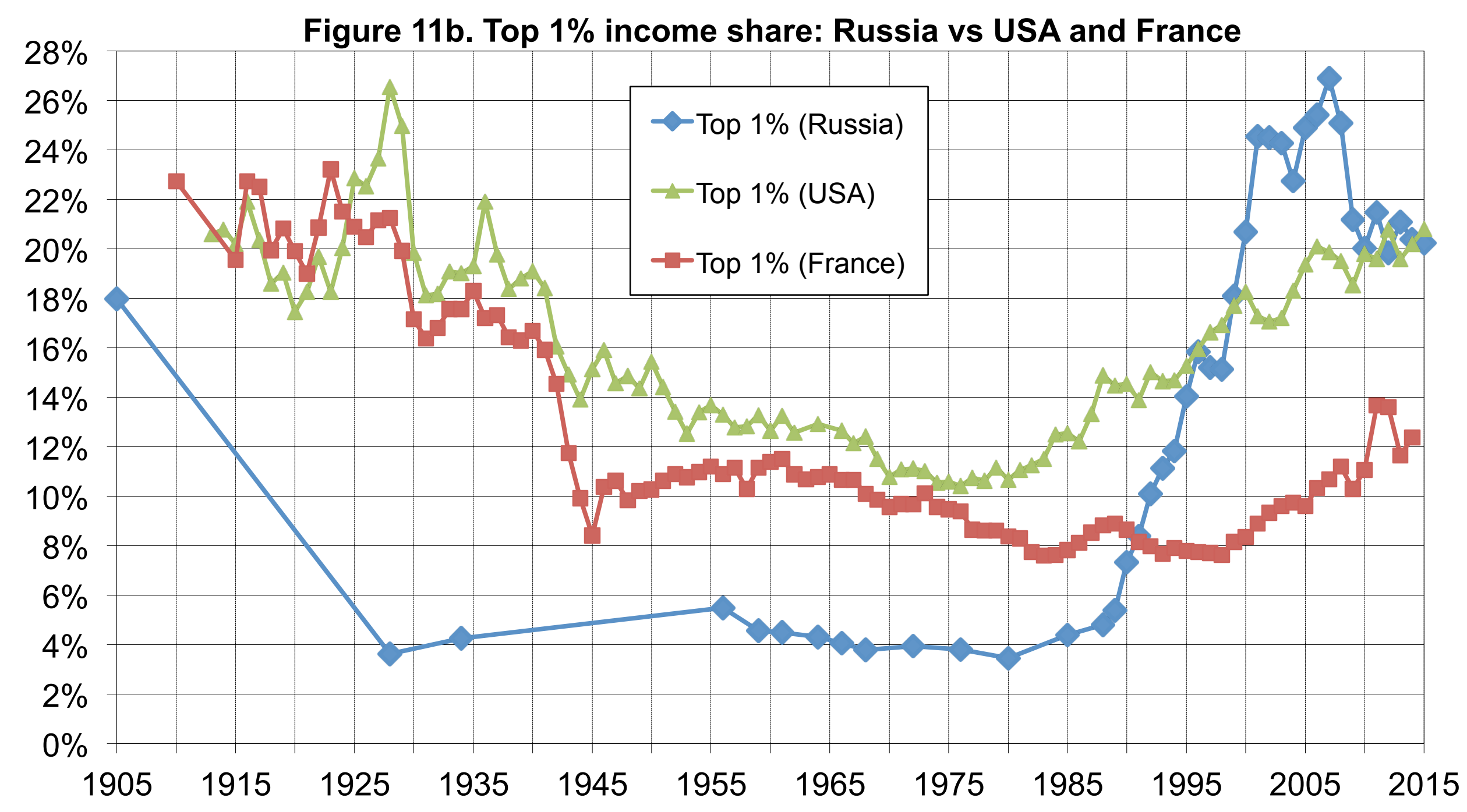

Distribution of pretax national income (before taxes and transfers, except pensions and unempl. insurance) among equal-split adults (income of married couples divided by two). Sources for USA and France: WID.world. 


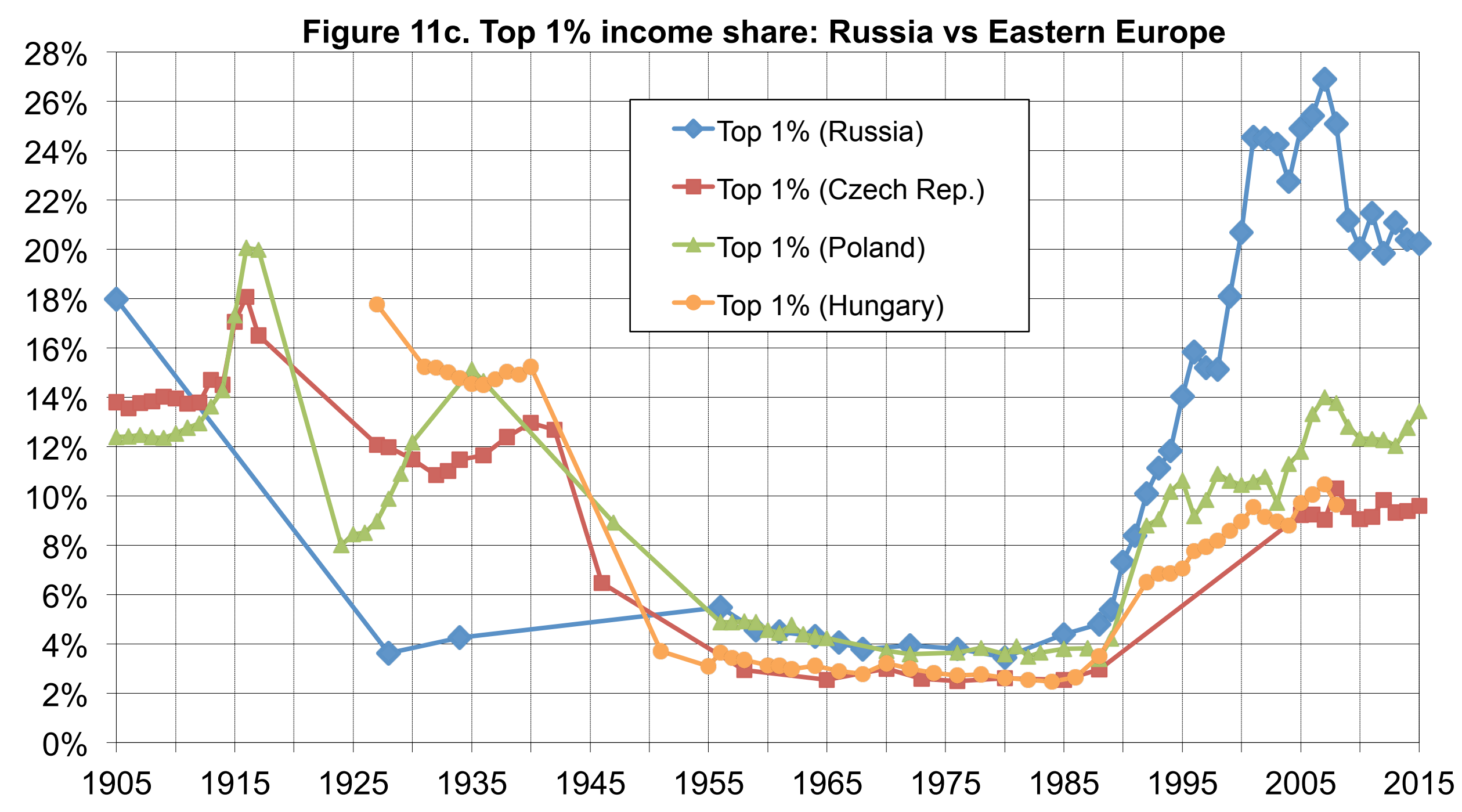

Distribution of pretax national income (Russia) or fiscal income (other countries). Source for Eastern Europe: Novokmet (2017); Hungary: Mavridis and Mosberger (2017). 
Figure 11d. Top income shares: Russia vs China

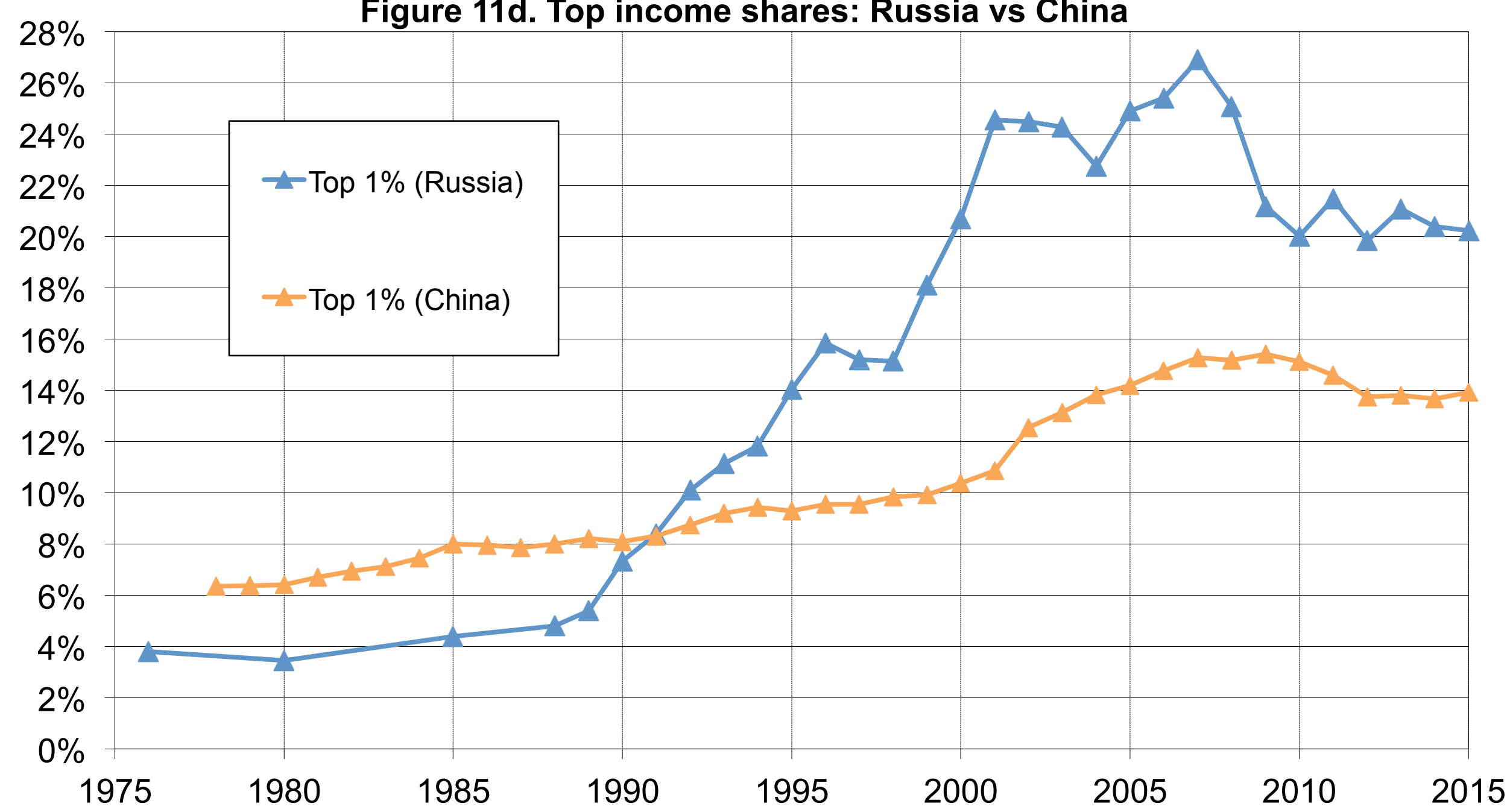

Distribution of pretax national income (before taxes and transfers, except pensions and unempl. insurance) among equal-split adults (income of married couples divided by two). Sources for China: WID.world. 
Figure 12a. Wealth Concentration in Russia, 1995-2015

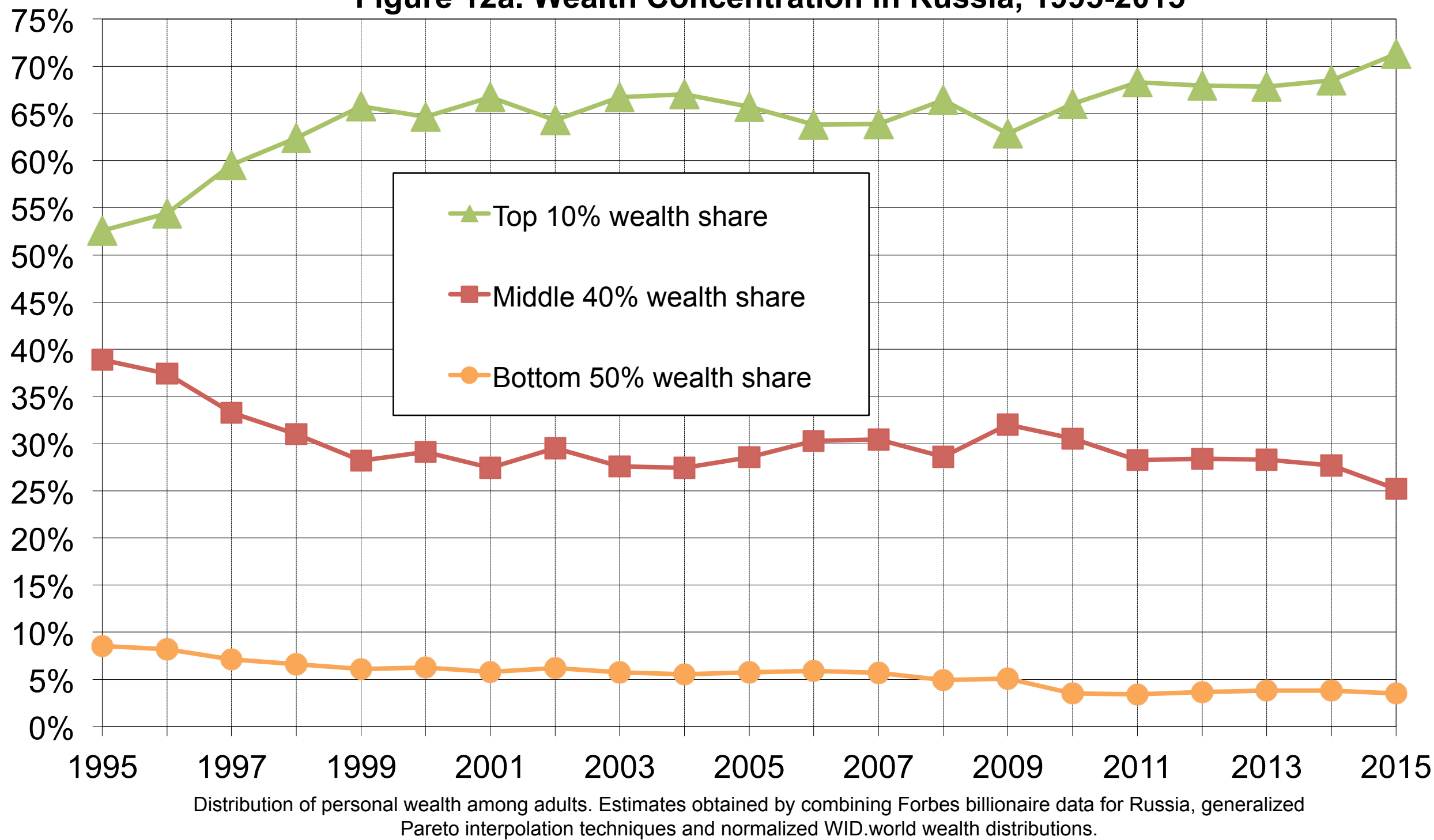


Figure $12 \mathrm{~b}$. Top $1 \%$ wealth share: Russia vs other countries

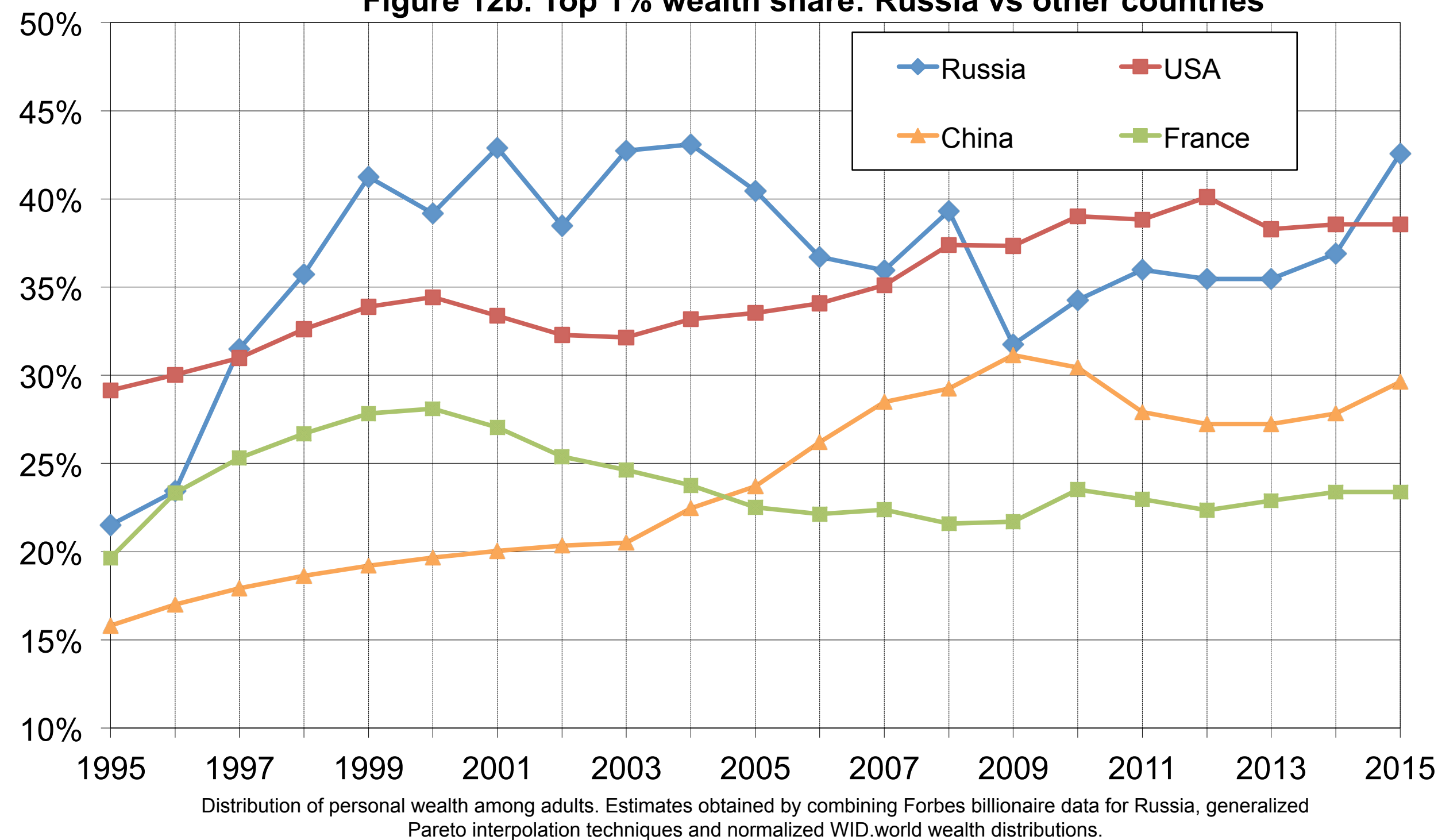




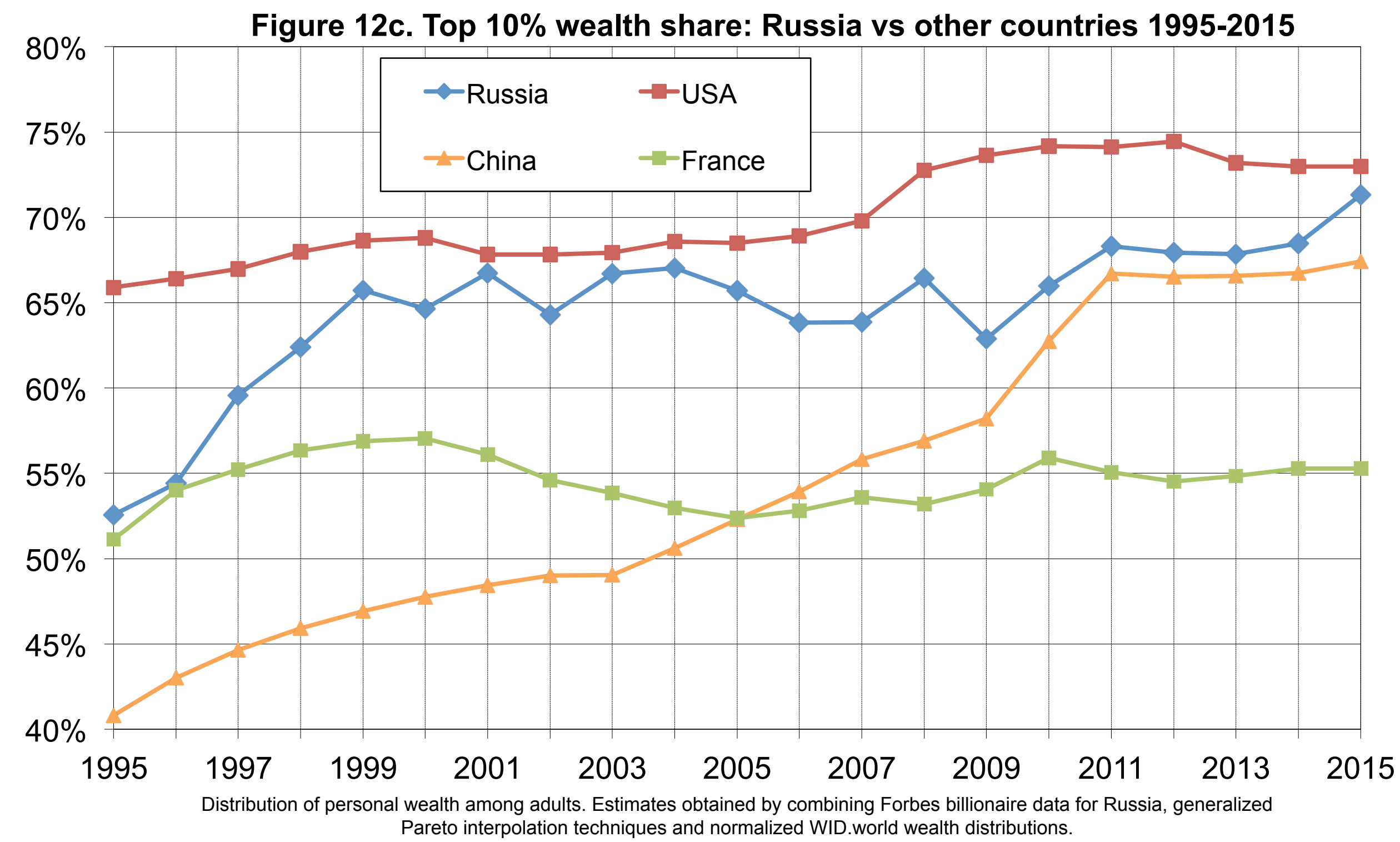


Table 3: Income growth and inequality in Russia 1905-2016

\begin{tabular}{|c|c|c|c|c|}
\hline \multirow{2}{*}{$\begin{array}{c}\text { Income } \\
\text { group } \\
\text { (distribution of per } \\
\text { adult pre-tax national } \\
\text { income) }\end{array}$} & \multicolumn{4}{|c|}{ Average annual real growth rates } \\
\hline & $1905-2016$ & $1905-1956$ & 1956-1989 & 1989-2016 \\
\hline Full Population & $1,9 \%$ & $1,9 \%$ & $2,5 \%$ & $1,3 \%$ \\
\hline Bottom 50\% & $1,9 \%$ & $2,6 \%$ & $3,2 \%$ & $-0,8 \%$ \\
\hline Middle $40 \%$ & $2,0 \%$ & $2,5 \%$ & $2,3 \%$ & $0,5 \%$ \\
\hline Top 10\% & $1,9 \%$ & $0,8 \%$ & $2,3 \%$ & $3,8 \%$ \\
\hline incl. Top 1\% & $2,0 \%$ & $-0,3 \%$ & $2,5 \%$ & $6,4 \%$ \\
\hline incl. Top $0.1 \%$ & $2,3 \%$ & $-1,2 \%$ & $2,7 \%$ & $9,5 \%$ \\
\hline incl. Top $0.01 \%$ & $2,5 \%$ & $-2,1 \%$ & $3,0 \%$ & $12,2 \%$ \\
\hline incl. Top $0.001 \%$ & $2,7 \%$ & $-3,0 \%$ & $3,3 \%$ & $14,9 \%$ \\
\hline
\end{tabular}

Distribution of pre-tax national income among equal-split adults. The unit is the adult individual (20-year-old and over; income of married couples is splitted into two). Fractiles are defined relative to the total number of adult individuals in the population. Corrected estimates (combining survey, fiscal, wealth and national accounts data). 
Table 1: Income thresholds and income shares in Russia, 2016

\begin{tabular}{lcccc}
$\begin{array}{c}\text { Income } \\
\text { group }\end{array}$ & Number of adults & Income threshold & Average income & Income share \\
Full Population & 114.930 .000 & $0 €$ & $23.181 €$ & $100,0 \%$ \\
Bottom 50\% & 57.465 .000 & $0 €$ & $7.877 €$ & $17,0 \%$ \\
Middle 40\% & 45.972 .000 & $13.959 €$ & $21.728 €$ & $37,5 \%$ \\
Top 10\% & 11.493 .000 & $36.311 €$ & $105.516 €$ & $45,5 \%$ \\
incl. Top 1\% & 1.149 .300 & $133.107 €$ & $469.105 €$ & $20,2 \%$ \\
incl. Top 0.1\% & 114.930 & $638.423 €$ & $2.494 .185 €$ & $10,8 \%$ \\
incl. Top 0.01\% & 11.493 & $3.715 .478 €$ & $12.131 .771 €$ & $5,2 \%$ \\
incl. Top 0.001\% & 1.149 & $18.769 .565 €$ & $58.575 .685 €$ & $2,5 \%$ \\
\hline \hline
\end{tabular}

Notes: This table reports statistics on the distribution of income in Russia in 2016 (expressed in PPP $€$ 2016). The unit is the adult individual (20-yearold and over; income of married couples is splitted into two). In 2016, 1 euro $=74,5$ rubles (market exchange rate) or 28,3 rubles (purchasing power parity). Income corresponds to pre-tax national income. Fractiles are defined relative to the total number of adult individuals in the population. Corrected estimates (combining survey, fiscal, wealth and national accounts data). Source: Appendix B. 
Table 2: Income growth and inequality in Russia 1989-2016

\begin{tabular}{|c|c|c|c|}
\hline $\begin{array}{c}\text { Income } \\
\text { group } \\
\text { (distribution of per } \\
\text { adult pre-tax national } \\
\text { income) }\end{array}$ & $\begin{array}{l}\text { Average annual real } \\
\text { growth rate } 1989- \\
2016\end{array}$ & $\begin{array}{l}\text { Total cumulated } \\
\text { real growth } \\
1989-2016\end{array}$ & $\begin{array}{c}\text { Share in total macro } \\
\text { growth } 1989-2016\end{array}$ \\
\hline Full Population & $1,3 \%$ & $41 \%$ & $100 \%$ \\
\hline Bottom 50\% & $-0,8 \%$ & $-20 \%$ & $-15 \%$ \\
\hline Middle $40 \%$ & $0,5 \%$ & $15 \%$ & $16 \%$ \\
\hline Top 10\% & $3,8 \%$ & $171 \%$ & $99 \%$ \\
\hline incl. Top $1 \%$ & $6,4 \%$ & $429 \%$ & $56 \%$ \\
\hline incl. Top $0.1 \%$ & $9,5 \%$ & $1054 \%$ & $34 \%$ \\
\hline incl. Top $0.01 \%$ & $12,2 \%$ & $2134 \%$ & $17 \%$ \\
\hline incl. Top $0.001 \%$ & $14,9 \%$ & $4122 \%$ & $8 \%$ \\
\hline
\end{tabular}

Distribution of pre-tax national income among equal-split adults. The unit is the adult individual (20-year-old and over; income of married couples is splitted into two). Fractiles are defined relative to the total number of adult individuals in the population. Corrected estimates (combining survey, fiscal, wealth and national accounts data). 
Table 3: Income growth and inequality in Russia 1905-2016

\begin{tabular}{|c|c|c|c|c|}
\hline \multirow{2}{*}{$\begin{array}{c}\text { Income } \\
\text { group } \\
\text { (distribution of per } \\
\text { adult pre-tax national } \\
\text { income) }\end{array}$} & \multicolumn{4}{|c|}{ Average annual real growth rates } \\
\hline & $1905-2016$ & $1905-1956$ & 1956-1989 & 1989-2016 \\
\hline Full Population & $1,9 \%$ & $1,9 \%$ & $2,5 \%$ & $1,3 \%$ \\
\hline Bottom 50\% & $1,9 \%$ & $2,6 \%$ & $3,2 \%$ & $-0,8 \%$ \\
\hline Middle $40 \%$ & $2,0 \%$ & $2,5 \%$ & $2,3 \%$ & $0,5 \%$ \\
\hline Top 10\% & $1,9 \%$ & $0,8 \%$ & $2,3 \%$ & $3,8 \%$ \\
\hline incl. Top 1\% & $2,0 \%$ & $-0,3 \%$ & $2,5 \%$ & $6,4 \%$ \\
\hline incl. Top $0.1 \%$ & $2,3 \%$ & $-1,2 \%$ & $2,7 \%$ & $9,5 \%$ \\
\hline incl. Top $0.01 \%$ & $2,5 \%$ & $-2,1 \%$ & $3,0 \%$ & $12,2 \%$ \\
\hline incl. Top $0.001 \%$ & $2,7 \%$ & $-3,0 \%$ & $3,3 \%$ & $14,9 \%$ \\
\hline
\end{tabular}

Distribution of pre-tax national income among equal-split adults. The unit is the adult individual (20-year-old and over; income of married couples is splitted into two). Fractiles are defined relative to the total number of adult individuals in the population. Corrected estimates (combining survey, fiscal, wealth and national accounts data). 